\title{
La problemática actual de la potestad disciplinaria sobre el alumnado de las universidades públicas
}

The current problem of the disciplinary power over the students of public universities

\author{
José Antonio Tardío Pato \\ Universidad Miguel Hernández de Elche \\ j.a.tardio@umh.es
}

\begin{abstract}
Resumen
Ante la ausencia de una ley que regule la potestad disciplinaria y el régimen sancionador en las universidades españolas, tal como contemplaba el Real Decreto 1791/2010, de 30 de diciembre, por el que se aprobó el Estatuto del Estudiante Universitario, el artículo se plantea la capacidad de las universidades de elaborar sus propias normas que, sin afectar a derechos fundamentales, ayuden a establecer los límites del ejercicio de esos derechos.

Se apoya para ello en el derecho comparado de países como Francia e Italia y en la jurisprudencia de los Tribunales Constitucional y Supremo españoles, para pronunciarse sobre la conveniencia de que se constituyan órganos colegiados (Comisiones de Disciplina), con autonomía funcional e independencia jerárquica, elegidos por el Claustro con una mayoría reforzada, que se encarguen de esta tarea.
\end{abstract}

Palabras clave: universidades públicas, estudiantes, potestad disciplinaria

\begin{abstract}
It is a striking fact the absence of a law that regulates the disciplinary power and the sanctioning regime in Spanish universities, as expressed in Royal Decree 1791/2010, of December 30, which approved the University Student Statute. This paper proposes the ability of universities to develop their own rules that, without affecting fundamental rights, help to establish the limits of the exercise of those rights.

It relies for this on the comparative law of countries such as France and Italy and on the jurisprudence of the Spanish Constitutional and Supreme Courts, to rule on the convenience of establishing collegiate bodies (Disciplinary Commissions), with functional autonomy and hierarchical independence, elected by the Senate with a reinforced majority, who are in charge of this task.
\end{abstract}

Keywords: public universities, students, disciplinary authority

Sumario. 1-La potestad disciplinaria como potestad sancionadora en las denominadas relaciones especiales de sujeción. 2-La potestad disciplinaria sobre el alumnado. 3-Conclusiones y valoración crítica. 4-Referencias. 
1. La potestad disciplinaria como potestad sancionadora en las denominadas relaciones especiales de sujeción

\subsection{Su explicación en la doctrina científica española}

A) Según la exposición más influyente en España, las sanciones disciplinarias son una modalidad de sanciones de autoprotección que se imponen a personas que están en una relación de sujeción especial con la Administración por infracciones cometidas a la disciplina interna por la que se rige dicha relación ${ }^{1}$.

a) Como sanciones de autoprotección se caracterizan porque, a través de las mismas, la Administración tutela su organización y orden internos, incluyendo el sistema de sus actos jurídicos, con un carácter doméstico y se contraponen así a las sanciones generales y a las penales, que son aquellas otras por las que tutela el orden social general, en un amplio sentido, el orden público².

b) Y, dentro de las de autoprotección, las disciplinarias van dirigidas a personas que están en una relación de sujeción especial con la Administración, diferenciándose así de otras de autoprotección, como son las de policía demanial, las rescisorias de actos administrativos favorables y las tributarias ${ }^{3}$.

Las relaciones especiales de poder son aquellas relaciones caracterizadas por una inserción duradera del administrado en la esfera organizativa de la Administración, bien sea como un medio de la Administración (por ej. el funcionario), bien sea como un simple requisito para poderse beneficiar de las ventajas de un establecimiento público (el enfermo del hospital, el escolar) ${ }^{4}$, que se contrapusieron por la doctrina alemana a las relaciones de sujeción general, generales de poder o de supremacía general, en las que el administrado actúa en su condición de privado es decir como centro de intereses personales propios, sin perjuicio de que su actuación en este orden de cosas le conecte necesariamente en mayor o menor medida con la organización política. Se presenta como objeto pasivo de las potestades ad-

1 E. GARCÍA DE ENTERRÍA (1976, p. 399-400), seguida de su incorporación posterior a la obra conjunta con TOMÁS-RAMÓN FERNÁNDEZ (2015a y 2015b). Otros trabajos y monografías importantes sobre las sanciones disciplinarias son los de NIETO GARCÍA, A. (1970, p. 44 y ss.); JIMÉNEZ-BLANCO Y CARRILLO DE ALBORNOZ, A. (1989, p. 109 y ss.); SUAY RINCÓN, J. (1989); TRAYTER JIMENEZ, J.M. (1992); CASTILLO BLANCO, F.A (1992); MARINA JALVO, B. (2006); y QUINTANA LÓPEZ, T. (2009).

2 E. GARCÍA DE ENTERRÍA (1976, p. 399-400). La distinción entre las sanciones administrativas generales y las penales no se basa en criterios sustanciales, sino en la distinta autoridad que las impone (jueces y magistrados, las penales, y autoridades administrativas, las de este tipo); la diferente finalidad que se persigue (dado que la Constitución fija como finalidad de las penas la reeducación y la reinserción social y tal fin no opera en las sanciones administrativas, que tan sólo obedecen a un objetivo de castigo); determinada cuantía recogida en el Código Penal (p. ej. más de 120.000 euros, según el art. $305 \mathrm{CP}$, para los delitos en materia tributaria, de modo que por debajo de ese umbral son infracciones administrativas generales); y el carácter más expeditivo de las sanciones administrativas frente a las sanciones penales (E. GARCÍA DE ENTERRÍA y TOMÁS RAMÓN FERNÁNDEZ, 2015b, p.166 y ss.)

3 E. GARCÍADE ENTERRÍA (1976, p. 400).

4 E. GARCÍA DE ENTERRÍA y TOMÁS RAMÓN FERNÁNDEZ (2015a, p. 237). M. LÓPEZ BENÍTEZ habla de incorporación duradera y efectiva del administrado en la esfera organizativa de la Administración (1994, p. 587), que puede responder a dos causas: que se inserta porque quiere obtener ciertas prestaciones de la Administración pública o porque ha hecho del servicio a la Administración su medio de vida (1994, p. 588-589). R. GARCÍA MACHO (1992, ps. 253-254) destaca el criterio de la convivencia entre la Administración y el administrado todo el día (soldados, presos) o la mayor parte del día (funcionarios, estudiantes). 
ministrativas generales tales como la tributaria, la expropiatoria, la sancionadora general, etc. ${ }^{5}$.

Pero también se ha destacado por otros autores como criterio subyacente a las relaciones de sujeción especial la presencia de situaciones en las que preceptos constitucionales establecen la limitación de algunos derechos fundamentales (a los presos, a los funcionarios, a las fuerzas armadas y cuerpos de seguridad) ${ }^{6}$; criterio que, como veremos, también ha encontrado reflejo en la jurisprudencia constitucional, no sin crítica de otros autores que también han enjuiciado concienzudamente tal tipo de relaciones ${ }^{7}$.

En su exposición inicial, incluye E. GARCÍA DE ENTERRÍA cinco grupos de administrados afectados por las citadas relaciones: a) los funcionarios; b) los usuarios de los servicios públicos (en los que se incluyen los alumnos universitarios, destinatarios del Reglamento de disciplina académica de 1954, pero también los usuarios del servicio de transporte por ferrocarril; c) los profesionales integrados en Colegios Profesionales en cuanto al ejercicio de su profesión, sobre la base del vínculo de miembros de la corporación; d) los miembros de otras corporaciones públicas no territoriales, según la misma técnica (como las comunidades de regantes); y e) los contratistas, y en particular a los concesionarios, respecto de los cuales se contempla la posible aplicación de las llamadas «penalidades», de la legislación contractual pública.

Posteriormente, él y TOMÁS-RAMÓN FERNÁNDEZ han añadido la mención a los recluidos en centros penitenciarios, a los que se ha referido la jurisprudencia constitucional como administrados insertos en relaciones especiales de sujeción (STC 2/1987 y múltiples posteriores) y que los citados autores integran dentro de los usuarios de los servicios públicos ${ }^{8}$ y ya no han mantenido la referencia ni a los miembros de otras corporaciones públicas no territoriales distintas de los colegios profesionales (como los miembros de las comunidades de usuarios de aguas), ni a los contratistas y concesionarios 9 .

E incidiendo en la distinción básica ya subrayada entre las relaciones de especial sujeción trabadas entre la Administración y aquellos que se integran con un medio de la misma (como el funcionario) y aquellas otras relaciones en las que la integración del administrado en la organización es un simple requisito para que éste pueda beneficiarse de las ventajas de un establecimiento público (como el enfermo

5 E. GARCÍA DE ENTERRÍA y TOMÁS RAMÓN FERNÁNDEZ (2015b, p. 20).

6 R. GARCÍAMACHO (1992, ps. 208-209).

7 Así, I. LASAGABASTER HERRARTE que resalta que no se entiende por qué pueden incluirse en tales relaciones colectivos como los estudiantes respecto de los cuales la Constitución no reconoce ninguna limitación de los mismos y porque, por otro lado, existen en nuestra Constitución limitaciones de derechos fundamentales que no están consideradas relaciones de sujeción especial, tales como la de los extranjeros, los parlamentarios, el Defensor del Pueblo, los miembros de las Juntas Electorales, los altos cargos de la Administración del Estado etcétera (1994, p. 162). Como igualmente sostiene que, si siguiendo a O. MAYER, las relaciones de supremacía especial significan una dependencia acentuada, tal criterio llevaría hoy a incluir dentro de tales relaciones situaciones distintas de las consideradas por tal autor, como la del parado perceptor de subsidio de desempleo, el pensionista o el incapacitado (1994, ps. 418-419).

8 E. GARCÍA DE ENTERRÍA y TOMÁS RAMÓN FERNÁNDEZ (2015b, p. 172).

9 E. GARCÍA DE ENTERRÍA y TOMÁS RAMÓN FERNÁNDEZ (2015b, p. 172). 
del hospital o el escolar), destacan una diferencia muy relevante. En el primer caso, cabe aceptar que la potestad organizativa pueda afectar derivativamente al administrado, pero solo dentro del ámbito propio de organización estrictamente entendida, no en cuanto a los aspectos que afecten a su posición de interés frente a la Administración. Por el contrario, en el segundo caso, si bien no puede negarse la potestad de la Administración de organizar el establecimiento público (el hospital, el establecimiento docente), resulta claro que, con este pretexto, una norma reglamentaria no habilitada por la ley no podrá alterar el status de usuario (calidad y cantidad de las prestaciones), ni añadir condiciones más gravosas para el disfrute de las mismas, mucho más si resulta que, en la base, existe un derecho fundamental (a la salud o a la educación, respectivamente) ${ }^{10}$.

Pero, además, añaden que no puede confundirse, como ha hecho con frecuencia la jurisprudencia, las relaciones de sujeción especial (la de los sectores indicados apostillo yo-) con cualquier caso de relación particularizada entre la Administración y un administrado ${ }^{11}$ (como las derivadas de determinadas autorizaciones administrativas - apostillo yo también teniendo en cuenta las situaciones que han llegado a ser calificadas como tal tipo de relaciones y han sido criticadas por dichos autores-).

Y, finalmente, sostienen que, tras la Constitución de 1978, el sometimiento pleno a la Ley y el Derecho de las Administraciones Públicas de su art. 103.1 y la vinculación de los derechos fundamentales de todos los poderes públicos sin excepción, de su art. 53.1, supone que las relaciones de sujeción especial no pueden ir más allá de legitimar una deducción de poderes implícitos en los otorgados por la Ley de una manera general o de un más amplio margen del papel del reglamento en el desarrollo de esa Ley, nunca una exención de ésta ${ }^{12}$.

B) Así pues, según tal caracterización, la potestad disciplinaria de las Administraciones Públicas (lo que es extensible a aquellos entes del sector público que han dejado de ser considerados Administraciones Públicas, como ha ocurrido con las Universidades) es el poder que tienen dichos entes de imponer sanciones para proteger su organización y el orden interno de la misma, a los que con su conducta amenazan dicho orden ${ }^{13}$ y se encuentren en una relación especial de sujeción (entendida en el sentido indicado).

C) Ahora bien, dado que la distinción entre relaciones generales de sujeción o de poder y las relaciones especiales se construyó por la doctrina alemana para justificar un estado de libertad restringida (O. MAYER) o un plus de sometimiento del ciudadano, para cuya concreción la Administración no necesitaría una cobertura de Ley, aun afectando a derechos fundamentales de aquél14, y que tanto la jurisprudencia de nuestro Tribunal Constitucional como la del Tribunal Supremo han asumido tal distinción con sus respectivos matices, los dos problemas centrales que plantea son: a) qué supuestos se encuentran integrados a la hora de la verdad dentro de las denominadas relaciones

10 E. GARCÍA DE ENTERRÍA y TOMÁS RAMÓN FERNÁNDEZ (2015a, p. 238).

11 E. GARCÍA DE ENTERRÍA y TOMÁS RAMÓN FERNÁNDEZ (2015b, p. 22).

E. GARCÍA DE ENTERRÍA y TOMÁS RAMÓN FERNÁNDEZ (2015b, p. 21).

13 De imposición de medios aflictivos a los perturbadores del buen orden administrativo, en términos de E. GARCÍA DE ENTERRÍA (1976, p. 400).

14 E. GARCÍA DE ENTERRÍA y TOMÁS RAMÓN FERNÁNDEZ (2015b, p. 172). 
de supremacía especial; y b) hasta dónde llega la relajación de los principios jurídicos aplicables a las relaciones de supremacía general o potestad sancionadora general y la eventual restricción de los derechos fundamentales, así como, dentro de ellos, en especial, el principio y derecho subjetivo de legalidad, tanto en su vertiente formal (la reserva de ley y colaboración reglamentaria), como en su vertiente material (la tipicidad: predeterminación normativa y taxatividad).

Lo veremos especialmente al analizar la jurisprudencia del Tribunal Constitucional, pero antes hagamos una breve referencia a su uso por nuestro Tribunal Supremo.

\subsection{La invocación por el Tribunal Supremo español de las relaciones de sujeción especial para justificar su regulación reglamentaria y la restricción de derechos fundamentales. El ámbito de los estudiantes universitarios como manifestación de ello}

Se ha destacado que, en la época de Franco, antes incluso de utilizar el TS tal terminología, en unas primeras sentencias, ya aplicó a situaciones calificadas por la doctrina científica como relaciones de sujeción especial la negación de exigencia de reserva de ley y la restricción de derechos fundamentales. Se admitieron, así, sanciones a los estudiantes de pérdida de matrícula por su participación en asambleas, en lugar de asistir a clase, con base en el Reglamento de Disciplina Universitaria de $1954^{15}$.

En un segundo momento, ya a partir de 1972, sí que se va a evocar explícitamente la presencia de relaciones de sujeción especial, en sanciones que llegan a ser especialmente duras, cómo la prohibición al recurrente de matricularse a perpetuidad en cualquiera de los centros universitarios del distrito de Madrid ${ }^{16}$.

Pero también llegó a declarar el Tribunal Supremo, al final del período, que una cosa era la restricción de derechos en ese tipo de situaciones y otra muy distinta la supresión pura y simple de los mismos, como impedir examinarse y concluir la carrera universitaria ${ }^{17}$.

Tras la aprobación de la Constitución, se ha mantenido la calificación de la situación como de sujeción especial y la aceptación de la restricción de derechos como el de educación, mediante sanciones congruentes con el fin del mantenimiento de la disciplina académica a los alumnos que incumplen las obligaciones exigibles en tal situación, conectadas con el cumplimiento de las funciones de la Universidad al servicio de la sociedad ${ }^{18}$. Se ha invocado la concurrencia de tal tipo de relaciones para la admisión del uso de tipos infractores abiertos, problemáticos para el principio de tipicidad, como el de "faltas muy graves de probidad"19. E incluso se ha admitido para justificar el debilitamiento del principio de res-

15 GARCÍA MACHO, R. (1992, ps. 159-160), que cita las SSTS de 3 de junio de 1968 (RJ 1968\2935) y 3 de octubre de 1968 (RJ 1968\4155). También LÓPEZ BENÍTEZ, M. (1994, p. 569 y ss.).

16 GARCÍA MACHO, R. (1992, p. 160), con cita de las SSTS de 2 de junio de 1972 (RJ 1972\2577) y 2 de abril de 1975 (RJ 1975\1909).

17 GARCÍA MACHO, R. (1992, ps. 160-161), con cita de la STS de 11 de marzo de 1976 (RJ 1976\1403), en la cual se admite que al menos pueda matricularse el alumno como libre, para proseguir los estudios.

18 STS de 7 de junio de 1999 (RJ 1999\5018), FJ 2, por haber realizado la recurrente fraude en los exámenes con uso de transmisor. Y STS de 7 de marzo de 2002 (RJ 2002 \), FJ 4, con cita de la anterior, al haber sido suplantado el recurrente por una persona desconocida, en connivencia con ella, para obtener el aprobado en el examen final de la asignatura.

19 STS de 15 de diciembre de 2000 (RJ 2000\9853), relativa a sanción disciplinaria a alumnos universitarios, 
erva legal con admisión de tipificación de infracciones y sanciones por vía reglamentaria en virtud de remisiones inespecíficas, sin un contenido legal mínimo ${ }^{20}$.

Se ha llegado a señalar que, en suma, se ha evocado la presencia de este tipo de relaciones no sólo por el TS, sino también por el TC, para justificar la validez de normas reglamentarias en supuestos de difícil conformidad con el principio de legalidad, actuando así de categoría comodín para evitar sentencias que, en una recta aplicación de los principios jurídicos, acarrearían consecuencias realmente perjudiciales para la comunidad ${ }^{21}$.

\subsection{La caracterización de tales sanciones y situaciones en la jurisprudencia constitucional española}

A) Los supuestos incluidos dentro de las denominadas relaciones de supremacía especial.

En relación con ésta primera cuestión, la jurisprudencia del Tribunal Constitucional, resaltando que la distinción de éstas con las de sujeción general es imprecisa ${ }^{22}$, en ocasiones, ha afirmado la concurrencia de tal relación sin aportar ningún criterio justificativo con respecto a la situación jurídica de referencia ${ }^{23}$, pero en la mayor parte de los casos sí que ha ofrecido algunos criterios materiales para tal calificación, que es interesante analizar para poder justificar o no la pertenencia a esta categoría de situaciones sobre las que no se ha pronunciado todavía el TC.

a) Un primer criterio explicativo, y a la vez justificativo, es que se trate situaciones en las que el ciudadano se integre en una institución preexistente que proyecta su «autoridad» sobre él, al margen de su condición común de ciudadanos, con adquisición por el mismo del status especifico de individuo sujeto a un poder público que no es el que, con carácter general, existe sobre el común de los ciudadanos ${ }^{24}$.

Y, sobre esa base, la determinación de las conductas identificables como antijurídicas en el seno de la institución es expresiva de la capacidad propia de autoordenación ${ }^{25}$ y de la necesidad de garantizar el orden interno de la institución administrativa correspondiente ${ }^{26}$.

Es el criterio que se utiliza en la STC 2/1987, al abordar las sanciones impuestas a un preso por el centro penitenciario, con invocación, sobre todo, de jurisprudencia

por invasión de los despachos de los profesores y suplantación fraudulenta de los ejercicios guardados en ellos, que habla expresamente de personas sometidas a "relaciones de dependencia especial" (FJ 5), para justificar la aplicación de jurisprudencia constitucional atinente a dicho tipo de relaciones que admitió el uso de tipos infractores abiertos como el de "faltas muy graves de probidad".

20 STS de 16 de marzo de 2001 (Sección Séptima, rec. 8018/1996, ROJ: STS 2124/2001) FJ 3, punto 4, en relación con el final del punto $3^{\circ}$. En sentido contrario, la STS de 15 de enero de 2009 (RJ 2009\469), FFJ $3^{\circ}$ y $4^{\circ}$. Sobre esta cuestión abundaremos más adelante.

22 Así lo dice en la STC 61/1990, FJ 6, tercer párrafo, y después lo recuerda en otras posteriores, con invocación de ésta (por ejemplo, STC 50/2003, FJ 5, segundo párrafo). 
del TEDH emitida en tal línea ${ }^{27}$. Pues, efectivamente, la STEDH de 28 de junio de 1984 (caso Campbell y Fell), recogiendo doctrina sentada en otras anteriores, admitió la existencia de un régimen disciplinario especial en materia carcelaria "por consideraciones de seguridad, del interés del orden, de la necesidad de pronta reprensión de la mala conducta de los detenidos, y por la responsabilidad que las autoridades deben tener sobre la disciplina dentro de sus establecimientos" 28 .

En Sentencias del TC posteriores sobre sanciones penitenciarias a presos se alude a la necesidad de velar por la seguridad y buen orden del centro como propio de las relaciones de sujeción especiales en estos $\operatorname{casos}^{29}$.

Más tarde, la mera invocación de que el supuesto era "manifestación de la capacidad propia de autoordenación correspondiente", aludida por la sentencia constitucional que acabamos de citar, le basta a la STC 69/1989, para afirmar que respondía a un caso de relación de sujeción especial la sanción impuesta a un policía nacional, sin más justificaciones ${ }^{30}$.

Y, en la misma línea, se invoca respecto de un policía municipal, como fundamento de este tipo de relaciones y sus sanciones, el "aseguramiento o la tutela de la organización administrativa (en este caso, la policial), de forma tal que esta Administración pueda llevar a cabo de manera satisfactoria la función de servicio público que tiene constitucionalmente encomendada [...] al objeto de permitir una adecuada realización de las funciones constitucional y legalmente atribuidas a los cuerpos y fuerzas de seguridad"31.

Como, en modo semejante, la STC 187/2015 califica de relación de especial sujeción aquella en la que se encuentran los funcionarios, diciendo que ello justifica los especiales deberes que se les imponen en razón de esta condición ${ }^{32}$, los cuales, junto con las sanciones que conlleva su incumplimiento, "sirven para garantizar el correcto funcionamiento de los servicios administrativos" 33 .

En los mismos criterios anteriores, aunque sin cita de los mismos, se está apoyando implícitamente la STC 106/2011, para considerar, como relación de sujeción especial, la de una militar, que dice que se deriva de su estatuto propio, dentro del

27 Dice la STC 2/1987 que en el caso enjuiciado "el tipo de infracciones y el alcance con que han sido contempladas [...] afectan sólo al orden en la prisión" (FJ 4, párrafo sexto).

La invocación de la STC 74/1985 la hace en el FJ 4, párrafo noveno. Ahora bien, si examinamos esta Sentencia, podemos comprobar que se afirma que "es claro que el interno de un centro penitenciario está respecto a la Administración en una relación de sujeción especial de la cual deriva para aquélla una potestad sancionatoria disciplinaria", pero no se invoca ningún criterio material para justificarlo (FJ 2, segundo párrafo). Por el contrario, la STC 2/1987 sí que lo ofrece, como hemos visto.

28 FJ 4, párrafo cuarto, de la STC 2/1987.

29 SSTC 204/2000 y 218/2002, FJ 4, letra c. La STC 116/2002 (FJ 5, párrafo cuarto) añade a lo anterior que frente a ello se sitúa el correlativo deber del interno de acatar y observar las normas de régimen interior reguladoras de la vida del establecimiento.

30 STC 69/1989, FJ 1, párrafo 2.

31 STC 188/2005, FJ 5, letra b. 
cual las relaciones de jerarquía y subordinación proyectan sus efectos de forma permanente ${ }^{34}$.

Con la invocación del criterio de relación de los sujetos con la Administración en situaciones que ésta goza de "capacidad administrativa de autoordenación", descarta como relaciones de supremacía especial las derivadas del control administrativo de la actividad industrial y las infracciones y sanciones previstas en la ley 21/1992, de industria, por ser una norma genérica, no específicamente destinada a regular tales relaciones ${ }^{35}$.

Y este mismo criterio es explicado como la existencia de peculiares relaciones y asimilables en las que entran en juego amplias facultades autoorganizativas, que confieren cierta prepotencia a la Administración para regularlas ${ }^{36}$, que podría llegar a permitir la consideración de relación de sujeción especial de la situación de los detectives privados sometidos en aquel momento a autorización administrativa previa $^{37}$.

Debe tenerse en cuenta en este sentido que, en la actualidad, la Ley 5/2014, de seguridad privada, les impone una serie de prohibiciones y restricciones muy fuertes ${ }^{38}$, que podrían justificar su consideración como relación como sujeción especial con base en el criterio de la jurisprudencia constitucional citado ${ }^{39}$; sin perjuicio de poderse llegarse a la misma conclusión con un criterio ulterior también manejado por tal jurisprudencia que citamos más adelante.

Otras sentencias han añadido al criterio anterior ("relaciones [...] expresivas de una capacidad administrativa de autoordenación") la mención a supuestos de organización de los servicios públicos $4^{\circ}$ (por lo que completa la precisión del alcance del primer criterio determinante de las relaciones de supremacía especial), para acabar declarando que el supuesto enjuiciado, la práctica de juegos o apuestas organizados por particulares o que tiene lugar en establecimientos de naturaleza privada no es una relación de sujeción especial, sino que se enmarca en el ámbito de las relaciones de supremacía o sujeción general, "ya que se trata de una actividad ajena a la organización de los servicios públicos por más que estrictamente regulada y limitada" ${ }^{41}$.

34 STC 106/2011, FJ 3, párrafo 4, con cita para lo último del art. 9 de las vigentes Reales Ordenanzas para las Fuerzas Armadas, aprobadas por Real Decreto 96/2009, de 6 de febrero.

35 STC 162/2008, FJ 3, letra b.

36 STC 61/1990, FJ 6, párrafo segundo.

37 STC 61/1990, FJ 6, párrafo segundo.

38 Arts. 5.1.h; 10; 24, 25; 37; 48; 49; 50 y 51 de la Ley 5/2014.

39 En este sentido, la STS de 15 de enero de 2009 (RJ 2009\469), FJ 4, que justifica la consideración de las empresas de seguridad privada como relación de sujeción especial, porque "la regulación que establece la Ley de Seguridad Privada integra funcionalmente la seguridad privada en el monopolio de la seguridad que corresponde al Estado, como señala en su Exposición de Motivos, considerando los servicios privados de seguridad como servicios complementarios y subordinados en relación con los de la seguridad pública. Este planteamiento, conjugado con los bienes jurídicos que se intentan salvaguardar, lleva al legislador a establecer una intensa intervención administrativa en relación con la habilitación, organización y desarrollo de las actividades de las empresas de seguridad privada".

40 STC 42/1987, que invoca el criterio de "relaciones [...] expresivas de una capacidad administrativa de autoordenación", en su FJ 2, párrafo 3, y añade la mención a la organización de los servicios públicos, en su FJ 2, párrafo 4.

41 STC 42/1987, FJ 2, párrafo 4. 
A nuestro entender, la referencia a la organización de los servicios públicos admite la interpretación de que no sólo engloba la garantía del orden de la institución respecto de su propio personal (una de las acepciones de servicio público en sentido subjetivo), sino también de los usuarios de esos servicios públicos (por la acepción de servicio público en sentido objetivo, como actividad prestacional de determinadas características), pero, a su vez, que se descartan actividades privadas no consideradas servicios públicos como son los establecimientos de juegos y apuestas del caso enjuiciado (más tarde, en sentencias posteriores que citaremos, otras actividades tampoco consideradas servicios públicos).

Este mismo criterio ya matizado será utilizado, más tarde, en la STC 81/2009, en la que se dice que, para la consideración de una relación como especial de sujeción, es necesario que se trate de "actuaciones que, por la relación de sus agentes con la Administración, pueden deparar la aceptación constitucional de un mayor margen de autonomía de ésta en la labor de tipificación de las infracciones, en atención a la capacidad administrativa de autoordenación", con cita para ello de las anteriores sentencias que acabamos de mencionar ${ }^{42}$. Y, en aplicación de este criterio, ha considerado que no posee el carácter de sanción de relaciones especiales de sujeción la impuesta a un delegado de campo, un directivo y un entrenador de un club de fútbol, por causar desórdenes durante la celebración de un partido de fútbol, con insultos al equipo arbitral e invasión del terreno de juego, dado que la norma invocada para aplicar dicha sanción era una norma genérica y no de las propias de las citadas relaciones especiales ${ }^{43}$.

b) Otro criterio próximo al primero, aunque con un ámbito de actuación distinto, es la referencia a relaciones en las que se ejercen potestades públicas para la ordenación y control del ejercicio de actividades profesionales, para velar que dicha actividad profesional se adecue a los intereses de los ciudadanos ${ }^{44}$ porque también está implícita la garantía del orden dentro de la actividad de la corporación. Y así califica de relación de sujeción especial la de un Arquitecto con su Colegio Profesional45, o la de un Abogado con su Colegio ${ }^{46}$. A lo que se añade, además que ello tiene fundamento expreso en el art. 36 de la Constitución ${ }^{47}$.

Pero, en otras sentencias, sin embargo, utiliza el TC un criterio delimitador de su calificación como relación de sujeción especial o tipo de explicación diverso a los anteriores: el enjuiciamiento de si se trata de situaciones y relaciones administrativas donde la Constitución, o la ley de acuerdo con la Constitución, han impuesto límites en el disfrute de los derechos constitucionales, han modulado tales derechos constitucionales, entre los que se encuentra el derecho a la legalidad sancionadora del art. 25.1 CE 48 .

\footnotetext{
42 STC 81/2009, FJ. 6, con invocación de las SSTC 2/1987, FJ 2; 42/1987 FJ 2; y 69/1989, FJ 1.

43 STC 81/2009, FJ. 6.

44 ATC 141/2004 y STC 188/2005, FJ 2.d.

45 STC 219/1989, FJ 2, párrafo 2.

46 ATC 141/2004.

47 STC 219/1989, FJ 2, párrafo 2.

48 SSTC 132/2001, FJ 4, párrafo 2, y 26/2005, FJ. 5, letras b y c.
} 
Se destaca por el mismo Tribunal que el art. 25.1 CE no contempla explícitamente ninguna situación o relación administrativa especial, pero que de la concurrencia del mismo con otras normas constitucionales sí se puede concluir que la propia Constitución contiene una modulación del derecho a la legalidad sancionadora en el ámbito de ciertas relaciones administrativas especiales.

Con él se reinterpretan declaraciones anteriores de concurrencia de relaciones de sujeción especial diciendo que, por lo anterior, se ha entendido afirmativamente la incidencia de tales situaciones "-al menos de forma implícita-, en relación con un preso (STC 2/1987, FJ 2), con un Policía Nacional (STC 69/1989 FJ 1) y con un Arquitecto colegiado, haciéndose mención expresa del art. 36 CE (STC 219/1989, FJ 3); igual que, aunque sólo tangencialmente y sin constituir propiamente ratio decidendi del caso, se aludió en la STC 61/1990, FJ 8 , a que un detective privado con autorización administrativa se encontraba en una <relación especial de sujeción〉, aun cuando aquella relación administrativa especial no tuviera base directa en la Constitución o en una ley conforme con la Constitución"49.

Precisamente, con este nuevo criterio, se facilita la explicación, como sanciones disciplinarias propias de relaciones de supremacía especial, aquellas del tipo de las impuestas a los detectives privados (aparte de que también era posible con un criterio anterior, como hemos argumentado atrás), porque, actualmente, la Ley 5/2014, de seguridad privada, no sólo exige a éstos una habilitación personal previa $^{50} \mathrm{y}$ dispone un control sobre la actividad mediante el requisito de presentación de declaración responsable ${ }^{51} \mathrm{y}$ una inspección encomendada a las Fuerzas y Cuerpos de Seguridad ${ }^{52}$, sino que, además, les impone una serie de prohibiciones y restricciones muy fuertes ${ }^{53}$, que en algún caso puede suponer modulación a sus derechos constitucionales, dado que su actividad incide en la seguridad ciudadana y en importantes derechos constitucionales de los ciudadanos. Aunque, al recoger una norma con rango de ley (la citada Ley 5/2014), la predeterminación normativa de infracciones y sanciones respectos de los mismos, así como la escala de sanciones y los criterios para su graduación ${ }^{54}$, con un grado de concreción aceptable, no puede decirse que se haya modulado en concreto el derecho a la legalidad sancionadora del art. 25.1 CE.

Pero, sin embargo, sobre la base de este nuevo criterio, ha considerado el TC que no concurría relación de supremacía especial en la prestación de servicios de trans-

49 SSTC 132/2001, FJ 4, párrafo 3, y 26/2005, FJ. 5, letra c

50 Dispone el art. 27.1 que, "para el ejercicio de las funciones de seguridad privada, el personal al que se refiere el artículo anterior habrá de obtener previamente la correspondiente habilitación del Ministerio del Interior, en los términos que reglamentariamente se determinen". Y añade el art. 28.1.i que, para la obtención de tal habilitación profesional, los aspirantes habrán de reunir, entre otros requisitos generales, "superar, en su caso, las pruebas de comprobación que reglamentariamente establezca el Ministerio del Interior, que acrediten los conocimientos y la capacidad necesarios para el ejercicio de sus funciones". 
porte en auto-taxi, porque ningún precepto constitucional prevé, ni explícita ni implícitamente, la limitación de derechos constitucionales en un ámbito de actividad económica privada, aunque esté intervenida y reglamentada, como es ese, ni tampoco ninguna Ley vigente al tiempo de la infracción sancionada modulaba el disfrute de los derechos fundamentales del taxista (STC 132/2001) ${ }^{55}$.

Lo mismo ha dicho de la relación entre Administración y los agricultores y bodegueros incorporados al Consejo Regulador de una denominación de origen en las SSTC $50 / 2003^{56}$ y $52 / 2003^{57}$.

Como también ha declarado lo propio, en el caso de concesionarios de expendedurías de tabaco: que "ningún precepto constitucional, ni tampoco una ley conforme con la Constitución, prevén, ni explícita ni implícitamente, la limitación de derechos constitucionales", en tal ámbito económico (STC 26/2005) ${ }^{58}$.

B) Hasta dónde llega la relajación de los principios jurídicos aplicables a las relaciones de sujeción general en el caso de las relaciones especiales de sujeción y, en especial, de los principios de reserva de Ley y de tipicidad-taxatividad.

Una vez analizados los criterios y supuestos de concurrencia de las relaciones especiales de sujeción, la segunda cuestión crucial es hasta dónde llega esa relajación de los principios jurídicos aplicables a las relaciones de supremacía general o potestad sancionadora general y en especial el principio de legalidad, tanto en su vertiente formal (la reserva de ley y colaboración reglamentaria), como en su vertiente material (la tipicidad: predeterminación normativa y taxatividad).

a) Se ha destacado, especialmente a raíz de la STC 61/1990, que no puede implicar la privación de sus derechos fundamentales. Y se han mencionado, entre otros derechos fundamentales no excluibles en las relaciones de sujeción especial (con ocasión del enjuiciamiento de sanciones administrativas a un recluso), el derecho a la defensa y a la asistencia letrada, el derecho a la utilización de los medios de prueba pertinentes y el derecho a la presunción de inocencia59.

Si bien, se siguen admitiendo limitaciones derivadas de las relaciones de sujeción especial, como ocurre con el derecho a la defensa de un recluso, que se considera inevitablemente condicionado por las posibles medidas de seguridad, tratamiento y buen orden legítimamente adoptables (por el Centro Penitenciario), de modo que, salvo que las decisiones de la Administración impliquen una privación real (al interno) de la posibilidad de articular su defensa, dichos condicionamientos no se consideran vulneración del art. 24.1 $\mathrm{CE}^{60}$.

55 STC 132/2001, FJ. 4, párrafo cuarto. Y también en la STC 13/2013, FJ 4, último párrafo.

56 STC 50/2003, FJ 5, párrafo 2.

57 STC 52/2003, FJ 9, párrafo 2. En esta Sentencia aparece citado, en los escritos del Fiscal, que la STS de 7 de junio de 1986 admitía el carácter de relación de sujeción especial de tal situación.

58 STC 26/2005, FJ. 5, letra c, párrafo segundo

59 STC 66/2007, FJ 3, que cita, a su vez, como anteriores las SSTC 81/2000, FJ 2; 27/2001, FJ 8; 116/2002, FJ 4; 236/2002, FJ 2; 9/2003, FJ 3; y 91/2004, FFJ 3 у 5.

60 STC 27/2001, FJ 12, párrafo segundo. 
Como también se ha planteado el alcance de las limitaciones y los límites infranqueables en relación con el derecho fundamental a la intimidad ${ }^{61}$.

Pero, sobre todo, se ha hecho hincapié en el derecho a la legalidad del art. 25.1 CE, en sus dos vertientes formal y material, con respecto al cual -dice la jurisprudencia constitucional- con carácter general, que la categoría jurídica de las relaciones de sujeción especial permitiría una cierta modulación (nunca su exclusión) de las exigencias formales y materiales del principio de legalidad en materia sancionadora ${ }^{62}$.

b) En relación con el principio de reserva de Ley (vertiente formal del principio de legalidad del art. 25.1 CE), sobresalen las siguientes cuestiones.

$1^{0}$. Hay que resaltar, en primer término, la declaración de que no es aplicable de manera retroactiva para considerar nulas e inaplicables disposiciones reglamentarias respecto de las cuales esa exigencia formal no existía antes de la Constitución ${ }^{63}$.

$2^{0}$. Una segunda cuestión es que se admiten con carácter general normas reglamentarias con habilitación legal previa en general, en los que el reglamento se limite a especificaciones de la tipificación recogida en normas con rango de Ley, sin introducir infracciones o sanciones nuevas o alterar su naturaleza y límites.

Esto, que se desprendía del derogado art. 23.2 de la Ley 50/1997, del Gobierno, y que fue recogido más claramente por el derogado art. 129.3 de la ley 30/1992 y está hoy incorporado al art. 27.3 de la Ley 40/2015, es ratio decidendi de la STC 16/2004 ${ }^{64}$.

$3^{\circ}$. Una tercera cuestión es la del alcance de dicho principio en relación con las relaciones de sujeción especial, con tres grandes aspectos: necesidad o no de habilitación legal previa; necesidad o no de un contenido mínimo de la norma legal, en lugar de remisión inespecífica; y posibilidad o no de que el reglamento introduzca nuevas infracciones y sanciones no establecidas en la Ley

Se había declarado, según una primera dirección jurisprudencial, que, en el seno de dichas relaciones, dicho principio perdía parte de su fundamentación, aunque no hasta el punto de admitir una sanción carente de toda base legal, que devendría lesiva del derecho fundamental ${ }^{65}$. Pero sí se consideró admisible que la norma legal hiciese

61 En la STC 218/2002 se enjuicia el respeto a un preso del derecho a la intimidad personal del art. 18.1 CE y se le otorga el amparo, porque no se había motivado por qué era necesario el cacheo con desnudo integral para el orden y la seguridad del establecimiento, en atención a la concreta situación de éste o al previo comportamiento del recluso, con cita de la anterior STC 57/1994, FJ 6.

62 Por todas, SSTC 162/2008, FJ 3; 81/2009, FJ 6; y STC 104/2009, FJ 6.

63 SSTC 11/1981; 101/1988, FJ 4; 69/1989, FJ 1, párrafo segundo; 219/1989, FJ 2, párrafo 2; 61/1990, FJ 8; 50/2003, FJ 4; 21/2010, FJ 4, párrafo 3; y 144/2011, FJ 4, párrafo 3.

64 STC 16/2004, FJ 8, párrafo 5 y ss. En ella se declara que la infracción tipificada en la norma reglamentaria impugnada es una concreción de la genérica contenida en la Ley, pues el hecho típico encaja -o es una concreción- en el art. 12.1 a) de la Ley de 1972, de medio ambiente atmosférico.

Ello, sin perjuicio de que tal sentencia haya sido criticada en el Voto particular a la misma y por M. REBOLLO PUIG y otros (2010, p. 117), porque los preceptos de la Ley de 1972 no sólo no contenían realmente una tipificación de infracciones, sino que ni siquiera establecían unos criterios mínimos de antijuridicidad, por lo que resultaba imposible que constituyesen cobertura legal de la infracción muy grave tipificada en la Ordenanza municipal de referencia.

65 STC 219/1989, FJ 2, párrafo segundo. 
una remisión al reglamento vacía de todo contenido sancionador material propio ${ }^{66}$, mientras que, por el contrario, en las relaciones de sujeción general, se venía reputando contraria al citado principio la simple habilitación a la Administración, por norma de rango legal vacía de todo contenido material propio ${ }^{67}$.

En la sentencia 61/1990, citada por la doctrina científica como paradigma del reforzamiento del sometimiento de las relaciones de sujeción especial a los principios generales del Derecho penal, en general, y al principio tanto de reserva de ley como de tipicidad, en particular ${ }^{68}$, se dice ciertamente que, en estas relaciones, los principios constitucionales ( $y$ derechos fundamentales en ellos subsumidos) no pueden ser también restringidos o perder eficacia y virtualidad, porque no se puede relativizar un principio sin riesgo de suprimirlo ${ }^{69}$.

Pero se añade que, siendo siempre exigibles los requisitos constitucionales de legalidad formal y tipicidad como garantía de seguridad del ciudadano, sí que admiten en estas relaciones de sujeción especial "una adaptación, nunca supresión, en concordancia con la intensidad de la sujeción", destacando como un supuesto de máxima intensidad el de la situación de preso $^{70}$.

En relación con la reserva de ley, dice con carácter general que el principio constitucional prohíbe "no la colaboración reglamentaria en la normativa sancionadora" sino "la remisión al reglamento que haga posible una regulación independiente y no claramente subordinada a la Ley". Pero, en el mismo párrafo, contrapone el caso de remisión de la norma legal a normas reglamentarias, en el que quedan «suficientemente determinados los elementos esenciales de la conducta antijurídica [...] y naturaleza y límites de las sanciones a imponer», al caso de las situaciones llamadas de sujeción especial, en las que lo que devendría lesivo del derecho fundamental que reconoce el art. 25.1 de la Constitución sería una sanción carente de toda base legal ${ }^{71}$.

No queda absolutamente claro si lo que está diciendo el Tribunal Constitucional es que, en las relaciones de sujeción especial, sólo se excluyen las normas reglamentarias sin habilitación legal previa (que es lo propio de los reglamentos independientes) o si también están prohibidas las remisiones inespecíficas de la ley al reglamento en las que la ley no ha establecido la regulación previa de los elementos esenciales de la conducta antijurídica y la naturaleza y límite de las sanciones a imponer, que sí se exige en las relaciones de sujeción general ${ }^{72}$.

Porque, además, si en las relaciones de sujeción especial se excluyesen las remisiones inespecíficas con habilitación legal previa, en realidad se estaría exigiendo el cumplimiento pleno y absoluto de la reserva de ley y entonces tendría poco sentido la invocación del Tribunal Constitucional de que, en tales relaciones, cabe una

66 STC 219/1989, FJ 3, párrafo primero.

STC 42/1987, FJ 2, párrafo 4. 
adaptación de tal reserva de ley. Pues, ¿cuál sería entonces el ámbito posible de la adaptación del principio de reserva de ley al que alude tal Sentencia?, ¿que con un contenido legal mínimo (elementos esenciales de infracciones y sanciones) fuese posible introducir infracciones y sanciones no recogidas en la Ley, tal vez?

Y no lo aclara el caso enjuiciado por la STC 61/1990, dado que la Orden Ministerial de 1981 que recogía las sanciones a aplicar a los detectives privados no tenía habilitación legal específica y por lo tanto directamente incumplía la primera premisa de la reserva de ley, sin plantearse el problema de la remisión inespecífica de la ley al reglamento en el caso enjuiciado.

La STC 26/2005, con referencia a una situación que acaba no encuadrándose en las relaciones de sujeción especial (concesionario de expendeduría de tabaco), parece incluir, en principio, las relaciones de sujeción especial cuando dice que, "con independencia de cómo se denomine la relación que une a la titular de la concesión con la Administración, no hay fundamento alguno para que la infracción por la que se sancionó a la recurrente carezca de la cobertura legal que, con carácter general, exige el art. 25.1 CE", añadiendo a continuación, con la conjunción "pues", que «la Ley sancionadora ha de contener los elementos esenciales de la conducta antijurídica y la naturaleza y límites de las sanciones a imponer" (FJ 5, letra c, párrafo segundo). Sin embargo, las sentencias que cita para esta última conclusión no se refieren, ninguna de ellas, a relaciones de sujeción especial y ella misma tampoco, como acabamos de indicar, por lo que no dejaría de ser un pronunciamiento obiter dicta para dicho tipo de relaciones.

Y sentencias posteriores a la 61/1990 y a la 26/200573, que sí son específicas de las relaciones de sujeción especial, tampoco dejan resuelta la cuestión, pues no exigen que la Ley sancionadora haya de contener los elementos esenciales citados, sino que lo único que dicen es que tampoco respecto de las relaciones de sujeción especial goza la Administración de un poder normativo carente de habilitación legal, aunque ésta pueda otorgarse en términos que no serían aceptables sin el supuesto de esa especial relación. Con esta base, no es extraño que el Tribunal Supremo haya llegado, en sentencias posteriores a la STC 61/1990, a interpretaciones y conclusiones distintas en cuanto a tal cuestión. La STS de 16 de marzo de $2001^{74}$ afirma la posibilidad de que, en las relaciones de sujeción especial en las que sí se cumpla el requisito de la habitación legal previa, sin embargo se admitan remisiones inespecíficas sin

73 SSTC 188/2005, FJ 2.d; 229/2007, FJ 2, último párrafo; y 187/2015, FJ 4, párrafo sexto.

La STC 81/2009 no enjuicia un supuesto de relación de sujeción especial, pero se refiere a ella para descartarla y dice lo mismo que las sentencias que acabamos de citar (FJ 5), sin aludir para nada a la necesidad de que "la Ley sancionadora ha de contener los elementos esenciales de la conducta antijurídica y la naturaleza y límites de las sanciones a imponer".

74 STS de 16 de marzo de 2001 (Sección Séptima, rec. 8018/1996, ROJ: STS 2124/2001), FJ 3, punto 4, en relación con el final del punto $3^{\circ}$. Se refería al Reglamento de la Policía de la Comunidad Autónoma del País Vasco aprobado por Acuerdo de 15 de junio de 1982 de la Junta de Seguridad del Estado y dicha Comunidad Autónoma, con la afirmación de que tenía su habilitación legal en la Disposición Transitoria Cuarta del Estatuto de Autonomía para el País Vasco (Ley Orgánica 371979) y de que, al tratarse de relaciones de sujeción especial, bastaba con la existencia de esa habilitación en una norma con rango legal y no se requería en este ámbito contenido material alguno. A dicha Sentencia se refieren como manifestación de esta interpretación M. REBOLLO PUIG; M. IZQUIERDO CARRASCO; L. ALARCÓN SOTOMAYOR y A.M. BUENO ARMIJO (2010, ps. 150-151). 
contenido material alguno. Y, sin embargo, la STS de 15 de enero de $2009^{75}$, después de calificar la situación de las empresas de seguridad como relaciones de sujeción especial, llega a una conclusión distinta, pues exige no sólo que la ley se remita al reglamento, sino que también defina los aspectos esenciales de las infracciones y sanciones y anula la sanción por considerar que el precepto reglamentario no se ha limitado a precisar o especificar lo dispuesto en la Ley con subordinación a la misma, sino que ha innovado con respecto a lo establecido en ella.

$4^{\circ}$. Otra cuestión, relacionada con la anterior, es el de las remisiones de segundo grado de un reglamento a otro reglamento, para sanar las deficiencias de la ley de cobertura.

Aquí ha declarado expresamente el TC, con carácter general (es decir sin matizar qué ocurre con las relaciones de sujeción especial), que, a la vez que carece de virtualidad y eficacia el reenvío de una norma legal sin contenido material alguno al reglamento, con mayor razón aún debe predicarse la falta de eficacia respecto a la remisión en segundo grado establecida en norma sin fuerza de ley, porque, aunque esta norma reglamentaria que realiza el reenvío contenga una regulación suficiente, si bien incompleta, de las conductas ilícitas y las sanciones aplicables, tal regulación no sana las insuficiencias atribuibles a la propia Ley que le sirve de cobertura, en atención al cumplimiento de la reserva constitucional de Ley ${ }^{76}$.

$5^{\circ}$. Y también se ha pronunciado el TC sobre la cuestión de la actualización o de la simple reiteración de normas reglamentarias preconstitucionales por normas reglamentarias postconstitucionales.

Ha declarado la imposibilidad de tal cosa, invocando que ese modus operandi "representaría convertir en buena medida en inoperante el principio de legalidad [...] con sólo reproducir, a través del tiempo, las normas reglamentarias sancionadoras preconstitucionales, manteniéndose así in aeternum, después de la Constitución, sanciones sin cobertura legal, incumpliéndose el citado precepto constitucional" 77.

Y lo ha hecho en supuestos de relaciones de sujeción generales ${ }^{78}$. Pero, por el propio contenido del argumento y su contundencia, podemos decir que difícilmente podría negarse su aplicación a las relaciones de sujeción especial.

Lo que sí se admite, en sentencias atinentes a supuestos de relaciones de sujeción especial, es la integración de normas sancionadoras preconstitucionales con normas posteriores preconstitucionales o postconstitucionales que precisen los deberes y obligaciones cuyo incumplimiento se sanciona siempre y cuando la integración no sea más que un reflejo casuístico de la formulación anterior que se desarrolla,

75 STS de 15 de enero de 2009 (RJ 2009\469), FFJ $3^{\circ}$ y $4^{\circ}$

SSTC 42/1987, FJ 3, y 52/2003, FJ 10

77 SSTC 177/1992, FJ 3, (sanción impuesta a una empresa hotelera, por sobreocupación de plazas); 305/1993, FJ 7, párrafo tercero (sanción a entidad propietaria de una discoteca por no respetar los horarios de cierre); 109/1994, FJ Único (sanción a entidades propietarias de una discoteca y un bar por no respetar los horarios de cierre); y 52/2003, FJ 10 (sanción a empresa bodeguera por poseer una cantidad de vino sin la preceptiva documentación que amparase su origen como protegido por la Denominación de origen correspondiente).

Puede comprobarse al examinar los supuestos de hecho de las SSTC citadas. 


\section{en términos muy estrictos y que no se aparte del mismo fundamento o bien jurídico protegido de la norma que desarrolla79.}

79 Así, en la STC 93/1992, se admite, en principio, que el Reglamento del Colegio cuya incompatibilidad con la reserva de Ley se denuncia goza de fundamento legal en cuanto infracciones y sanciones, porque -dice la Sentencia- que "la infracción del régimen de tarifación de fórmulas, de ventas de menudeo, de turnos y horarios y de colocación de carteles", del art. 43e) del Reglamento del Colegio de Madrid, no es más que un reflejo casuístico de la fórmula legal, establecida por la Base XXVI del Estatuto general de 1934, que tipifica como falta leve "el incumplimiento de los preceptos reglamentarios que no entrañen perjuicio moral o material" a la colectividad [Bases XXVI, ap. b), y XXVII.b], habida cuenta que el Estatuto asimila el término "preceptos reglamentarios" con el de "Acuerdos de los Colegios" (FJ 7, párrafo sexto).

Ahora bien, la conducta por la que se le sanciona (haber abierto un día de agosto, en contra de los turnos de vacaciones, según los cuales le hubiese correspondido cerrarla) se considera que no entra dentro del tipo, que en estos casos no sólo exige el examen de la norma inicial en blanco de remisión (la del Estatuto general de 1934), sino la de integración (en este caso, el art. 43e del Reglamento del Colegio de Madrid). Así se colige de lo que expone en su FJ 8, párrafo tercero.

En este punto, declara que los turnos fijados en los citados Acuerdos colegiales de 1980 "que, por definición y por congruencia con su finalidad de asegurar el abastecimiento de medicinas a la población, conllevan la fijación de unos calendarios y horarios mínimos de apertura, de obligada observancia para los titulares de las farmacias. Pero esta exigencia es distinta a la obligación de cerrar un mes durante el período estival, que ha sido impuesta por el Colegio por razones de compensación económica entre los distintos farmacéuticos" (FJ 8, párrafo tercero).

$\mathrm{Y}$, por eso, junto a otros aspectos (entre los que destaca la falta de publicación de los acuerdos de 1980), estima el recurso de amparo.

En la STC 153/1996, cuyos hechos y sujetos son los mismos que en la STC 93/1992, se alega por el Colegio Oficial de Madrid que el TC, en la anterior sentencia citada, no tuvo en cuenta la Orden Ministerial de 17 de enero de 1980, que en su art. 7 dispone: " Los Colegios Oficiales de Farmacéuticos ordenarán, con carácter general y/o especial, los horarios de servicio público de las oficinas de Farmacia, los turnos de guardia y servicios de urgencia y los de vacaciones. Tal ordenación se establecerá de conformidad con las necesidades asistenciales y sanitarias de la población, así como en función de las características urbanas y geográficas, en orden a obtener la mayor eficacia en la asistencia". Y el TC contesta ahora en la STC 153/1996 que la lectura de esa norma no hace sino confirmar el criterio sostenido por este Tribunal en la STC 93/1992, pues ninguna duda cabe de que la ordenación referida, expresamente destinada a garantizar la prestación del servicio público de farmacia, no guarda relación con la sanción impuesta, que pretende impedir que se alteren ciertos equilibrios económicos entre los profesionales afectados. Como se dijo en la STC 93/1992, fundamento jurídico $9^{\circ}$, los bienes jurídicos protegidos son distintos en uno y otro caso (FJ 4, párrafos primero y segundo).

Por lo tanto, la conclusión es que no se cumple con el art. 25.1 CE, porque lo especificado en la norma de integración del tipo, en el caso de esta Sentencia, la Orden Ministerial de 17 de enero de 1980 (que es posterior a la Constitución), no se ajusta al tipo de la norma sancionadora anterior a la que se dice integrar (la de la Base XXVI del Estatuto general de 1934), por tener un fundamento distinto.

También se alude en las Sentencias anteriores a la STC 219/1989, en la que sí se considera ajustada al art. 25.1 CE la sanción impuesta a un colegial Arquitecto, sobre la base de una integración del tipo establecido en una norma anterior por otra norma posterior que no se aparta del fundamento de la primera (véase las SSTC 93/1992, FJ 9, párrafo primero y 153/1996, FJ 3, párrafo quinto, inciso final).

En tal Sentencia 219/1989, el tipo inicial venía dado por el art. 39 de los Estatutos de 1931, que tipificaba como sanción la conducta del colegiado que «se aparta(ba) de los deberes sociales, profesionales o legales relacionados con la profesión, y especialmente de los determinados en estos Estatutos, en los Reglamentos y en los acuerdos de las Juntas». Y la integración de dicho tipo se hacía por unas Normas Deontológicas que, según el TC, definían con precisión los deberes profesionales de los colegiados (FJ 5, párrafo cuarto).

Tales Normas Deontológicas son las de Actuación Profesional de los Arquitectos, aprobadas por la Asamblea General de las Juntas de Gobierno de los Colegios del Arquitectos de España el 22 de noviembre de 1971 y modificadas el 28 de noviembre de 1975.

$\mathrm{Y}$ el actor fue sancionado disciplinariamente por los órganos competentes del Colegio de Arquitectos de Valencia y Murcia por la conducta consistente en "permitir o en colaborar a la alteración de la verdad en la declaración de la extensión de parcelas sobre las que se iba a construir, a falsear los planos con superposición de parcelas, a construir en terrenos rústicos o no urbanizables y a ejecutar obras no coincidentes con los proyectos presentados".

En realidad, a nuestro entender, en estos casos, la cuestión se puede resolver sin necesidad de acudir a la integración de normas sancionadoras por otras posteriores, por la vía de la integración de los conceptos jurídicos indeterminados que las mismas contengan, en la que pueden entrar en juego otras normas jurídicamente válidas que puedan servir para la determinación en el caso concreto de lo que era indeterminado (impreciso) en su formulación genérica y abstracta en la norma que lo contiene. 
c) Por lo que al principio de tipicidad (vertiente material del principio de legalidad) respecta, recordemos, desde el punto de vista conceptual, que dicho principio comporta el mandato de taxatividad o certeza ${ }^{80}$ y se traduce en la exigencia de predeterminación normativa de las conductas constitutivas de infracción, de las sanciones correspondientes, de la escala de sanciones, de la graduación de dichas sanciones y de la correlación entre infracciones y sanciones; de modo que permita predecir con suficiente grado de certeza si una conducta constituye infracción administrativa y el tipo de sanción (y grado de la misma) que puede ser impuesta por tal conducta, en caso de que constituya infracción ${ }^{81}$.

Y su fundamento reside en los principios constitucionales de libertad del art. 1.1 CE y de seguridad jurídica del art. $9.3^{82}$, así como que la efectividad de la previsión normativa de infracciones y sanciones con la mayor precisión posible ${ }^{83}$ no dependa de una decisión prácticamente libre y arbitraria del intérprete y juzgador ${ }^{84}$.

En relación con la tipicidad se plantean, principalmente, con carácter general, las cuestiones de la exclusión por el mismo de la interpretación extensiva y de la analogía in malam partem ${ }^{85}$; la exclusión de la tipificación mediante cláusulas generales o indeterminadas de infracción, tan abiertas por su amplitud, vaguedad o indefinición, que su efectividad dependa de una decisión prácticamente libre y arbitraria del intérprete y juzgador ${ }^{86} ; \mathrm{y}$, por último y en sentido opuesto a

80 STC 229/2007, FJ 4, párrafo segundo.

81 Así lo recoge en la STC 219/1989, FJ 4, párrafo primero y en la STC 61/1990

82 SSTC 101/1988, FJ 3 y 239/1988, FJ 2, párrafo 2).

83 SSTC 242/2005, FJ 2 y 162/2008, FJ 1, párrafo 3.

84 Por todas, SSTC 100/2003, FJ 2; 26/2005, FJ 3; y 242/2005, FJ 2, párrafo 3.

85 Ya veremos en párrafos sucesivos que antes de la Ley 30/1992 fue aplicado por la STC 182/1990, en un supuesto de relaciones especiales de sujeción.

Más tarde, lo recogió la Ley 30/1992, en su art. 129.4, de la que ha pasado al art. 27.4 de la Ley 40/2015.

La STC 229/2007 (FJ 4, párrafo 2) recuerda que en el ámbito penal está vedada la interpretación extensiva y la analogía in malam partem (SSTC 81/1995, de 5 de junio, FJ 5; 34/1996, de 11 de marzo, FJ 5; 64/2001, de 17 de marzo, FJ 4; 170/2002, de 30 de septiembre, FJ 12), es decir, la exégesis y aplicación de las normas fuera de los supuestos y de los límites que ellas mismas determinan, pues, en caso contrario las mismas se convertirían en fuente creadora de delitos y penas y, por su parte, el aplicador de la nueva norma así obtenida invadiría el ámbito que sólo al legislador corresponde, en contra de los postulados del principio de división de poderes. Y lo aplica al ámbito sancionador administrativo y, además, en el ámbito de la relación de sujeción enjuiciada (la de un Registrador Mercantil con la Dirección General de los Registros y del Notariado), otorgando el amparo solicitado con anulación de la sanción, en los términos en los que abundaremos más adelante.

E indica el TC en otras sentencias que "la tarea del Tribunal Constitucional en este punto se limita a verificar si la interpretación realizada por los órganos judiciales era una de las interpretaciones posibles de la norma en atención a los valores de seguridad jurídica y de monopolio legislativo, en la determinación esencial del ilícito administrativo, y a supervisar externamente que la interpretación adoptada responde a unas reglas mínimas de interpretación, de modo que quepa afirmar que la decisión sancionadora era un resultado previsible, en cuanto razonable, de lo decidido por la soberanía popular, por lo que se proscriben constitucionalmente aquellas otras incompatibles con el tenor literal de los preceptos aplicables o inadecuadas a los valores que con ellos se intenta tutelar (SSTC 137/1997, FJ 7; 151/1997, FJ 4; 25/1999, FJ 3; y 52/2003, FJ 5, párrafo 3).

86 Así, la STC 162/2008 rechazó el tipo legal "el incumplimiento de cualquier otra prescripción reglamentaria no incluida en los apartados anteriores", pues la pura remisión a los reglamentos, sin más acotaciones dificulta de tal modo el conocimiento de lo prohibido - al exigir la búsqueda de los reglamentos aplicables y de las normas que en ellos establecen obligaciones - que permite afirmar ya desde la norma de remisión que no queda salvaguardado suficientemente el valor de la seguridad jurídica al que sirve, entre otras, la proclamación del art. 25.1 CE (STC 162/2008, FJ 2, párrafo 4, que invoca como antecedentes las SSTC 60/2000, FJ 4, y 341/1993, FJ 10). 
lo anterior, la admisión de la tipificación mediante "conceptos jurídicos indeterminados" 87 .

En el principio general de libertad (sobre el que se organiza el Estado de Derecho), porque impone que las conductas sancionables sean una excepción a la regla general de la libertad y, en tanto que excepción, deben estar totalmente delimitadas por el Ordenamiento jurídico, ya que la libertad de la regla general de lo no prohibido.

Y, en el principio de seguridad jurídica, proclamado por el art. 9.3 CE, porque exige que los ciudadanos puedan predecir con certeza las consecuencias de sus actos, dado que la seguridad jurídica es aquí saber a qué atenerse. Sobre este aspecto también han hecho hincapié las SSTC 242/2005 (FJ 2, párrafo 3) y 162/2008 (FJ 1, párrafo 3 ), que resaltan que se trata de que los ciudadanos puedan conocer de antemano el ámbito de lo prohibido y prever, así, las consecuencias de sus acciones.

Pero a nosotros lo que nos interesa, ahora, es el alcance de lo anterior en el caso de las relaciones especiales de sujeción (base de la potestad disciplinaria), es decir, en qué podrán consistir las adaptaciones o relajaciones de tal principio derivadas de tal tipo de relación, sin llegar a la supresión del mismo.

$1^{\mathrm{o}}$. En un primer momento, se admitió en el marco de estas relaciones especiales, la tipificación por una remisión bastante abierta a las normas reglamentarias (concretamente a los acuerdos de los Colegios Profesionales definidores de los «deberes sociales, profesionales o legales relacionados con la profesión» vigentes en cada momento), por considerar que generaba una más que razonable certeza en cuanto a los efectos sancionadores de su trasgresión, desde tiempo inmemorial y de manera regular ${ }^{88}$.

Sin embargo, posteriormente, se va a rechazar un tipo de remisión de ese tipo, tan amplia (concretamente, el tipo legal "incumplimiento de cualquier otra prescripción reglamentaria no incluida en los apartados anteriores"), por considerar que la pura remisión a los reglamentos sin más acotaciones dificulta el conocimiento de lo prohibido ${ }^{89}$.

Sin embargo sí ha admitido la jurisprudencia del TC la remisión en una tipificación de una ley a otros preceptos legales de otras leyes donde se recoja la infracción (SSTC 341/1993 FJ 10; 60/2000, FJ 8, y 242/2005, FJ 3, párrafo 4 ), por considerar que en tales casos era posible conocer de antemano por los destinatarios de las normas el ámbito de lo proscrito y prever, así, las consecuencias de sus acciones.

87 Según la STC 69/1989, el principio de tipicidad es compatible con la utilización por el legislador de conceptos jurídicos indeterminados (en el caso enjuiciado, "desobediencia o irrespetuosidad a los superiores o autoridades"), siempre que su concreción sea razonablemente factible en virtud de criterios lógicos, técnicos o de experiencia y permitan prever, por consiguiente, con suficiente seguridad, la naturaleza y las características esenciales de las conductas constitutivas de la infracción tipificada (FJ 1, párrafo quinto).

Más tarde, también la STC 184/1995, que destaca tal compatibilidad si el significado puede ser inferido por el intérprete mediante la valoración sistemática de la norma, atendiendo a la finalidad y fundamento de la misma.

88 Dice la STC 219/1989 (FJ 5, párrafo tercero) que resulta claro también, en el ámbito específico de las relaciones especiales de sujeción, cabe la remisión a los Acuerdos de las Juntas definidores de los «deberes sociales, profesionales o legales relacionados con la profesión», que debe entenderse referida, muy especialmente, a las Normas Deontológicas que dichas Juntas puedan aprobar y se hallen vigentes en cada momento. Porque es generalmente sabido, por lo demás, $y$, por tanto, genera una más que razonable certeza en cuanto a los efectos sancionadores, que las transgresiones de las normas de deontología profesional, constituyen, desde tiempo inmemorial y de manera regular, el presupuesto del ejercicio de las facultades disciplinarias más características de los Colegios profesionales. 
$2^{\circ}$. Un adecuado rigor en la tipificación de infracciones y sanciones y la conexión entre ambas se exige en la STC 61/1990 (invocada como paradigma del reforzamiento de garantías en este tipo de relaciones). Primero, indica que en las mismas ha de darse, con independencia del rango legal, la tipificación de las infracciones, la graduación o escala de las sanciones y la correlación entre unas y otras ${ }^{90}$. A continuación, enjuicia si existe en el caso analizado una verdadera predeterminación de comportamientos y una conexión entre éstos y las sanciones que se enumeran, para que no se permita de hecho al órgano sancionador actuar con un excesivo arbitrio ${ }^{91}$. $\mathrm{Y}$, finalmente, concluye que no se cumple en tal caso con lo anterior, porque la norma enjuiciada se limita a establecer una enumeración de posibles sanciones, sin referencia precisa a las conductas; lo que contribuye junto a otros aspectos enjuiciados anteriormente al otorgamiento del amparo.

$3^{0}$. Y la interpretación analógica y la extensiva se rechaza en este tipo de relaciones, en otra Sentencia posterior (STC 182/1990), en la misma línea de reforzamiento de garantías. Concretamente, declara inconstitucional la interpretación amplia del tipo "incumplimiento de los deberes y obligaciones del funcionario" (por tanto, bastante semejante al tipo mencionado atrás, que sí se admitió en primera sentencia constitucional) basada en la diferencia del criterio interpretativo de las normas en un asunto por el superior respecto del inferior sancionado, con invocación de que con ello se incurrió en la aplicación analógica que prohíbe el principio de tipicidad.

Pero, sobre todo, en la Sentencia que se ha llegado más lejos en cuanto a la anulación de una sanción por derivar de una aplicación analógica o extensiva in malam partem ha sido en la STC 229/2007, al rechazar la reconducción del supuesto de "cobro de derechos arancelarios improcedentes", no existente explícitamente, al tipo infractor recogido explícitamente de "cobro de derechos arancelarios procedentes pero en cuantía inadecuada" 92.

C) La incidencia de otros principios en las relaciones especiales de sujeción, como el non bis in idem.

Se suele destacar como una peculiaridad de las relaciones especiales de sujeción la admisión en las mismas del non bis in idem, pero ello es más bien una consecuencia natural de las exigencias de dicho principio, pues el mismo no sólo exige la identidad de hechos y sujetos, para excluir la dualidad de sanciones (vertiente material) y de procedimientos (vertiente procesal o procedimental) , sino también la identidad de fundamento punitivo y, precisamente, en el ámbito de este tipo de relaciones y sus sanciones se da esa diversidad de fundamentos sancionadores (aunque no es el único caso, pues también suele darse en el caso de las sanciones administrativas rescisorias de actos administrativos favorables) respecto del propio de las sanciones penales.

Sin embargo, sí ha admitido la jurisprudencia del TC la remisión en una tipificación de una ley a otros preceptos legales de otras leyes donde se recoja la infracción (SSTC 341/1993 FJ 10; 60/2000, FJ 8, y 242/2005, FJ 3, párrafo 4 ), por considerar que en tales casos era posible conocer de antemano por los destinatarios de las normas el ámbito de lo proscrito y prever, así, las consecuencias de sus acciones.

90 STC 61/1990, FJ 9, párrafo primero.

91 STC 61/1990, FJ 9, párrafo segundo.

92 STC 229/2007, FJ 5, letra b, párrafo quinto. 
Un ejemplo muy claro es el que aparece en una de las sentencias más representativas de este principio, la STC 234/1991, que declara compatible una sanción penal y una sanción disciplinaria a un policía gubernativo. La sanción disciplinaria, de traslado forzoso, tiene su base en el fundamento de que la eficacia del servicio policial se ve perjudicada cuando los encargados de llevarlo a cabo cometen aquellos mismos actos que, en interés de toda la sociedad, tienen como misión evitar. Mientras que la sanción penal responde al fundamento general de disuasión para que no se comentan los ilícitos tipificados por el Código penal y al fin de reeducación y reinserción social proclamado en el art. 25.2 CE $^{93}$.

Como veremos más adelante, esa misma dualidad de fundamentos se reconoce en el caso de la potestad disciplinaria de los alumnos universitarios y, por eso, se admite la dualidad de sanciones penales y disciplinarias en dicho ámbito.

Recordemos, en cualquier caso, que la diferencia de fundamento se identifica con la diferencia de interés jurídicamente protegido en cada caso y que además se requiere que la sanción sea proporcionada a la diversa protección de intereses ${ }^{94}$.

\section{La potestad disciplinaria sobre el alumnado}

\subsection{Su justificación como relación de sujeción especial}

A) No tenemos constancia de que el Tribunal Constitucional español se haya pronunciado sobre la naturaleza jurídica de las relaciones entre las Universidades públicas y sus alumnos, teniendo en cuenta que, cuando dicho Tribunal enjuició un recurso de amparo relativo a una sanción disciplinaria a un alumno, no entró en la calificación jurídica de tal relación, al considerar, en su Sentencia 62/1992, ajustada a Derecho y no incongruente la Sentencia del Tribunal Supremo que estimó la demanda por violación en el expediente administrativo del art. 24 de la Constitución, con apreciación de los vicios procedimentales denunciados, sin pronunciarse sobre la vulneración del art. 25.1 aducida por el recurrente.

Por ello, cabe plantearse como primera cuestión, si, no sólo desde el prisma de la doctrina científica que se ha manifestado sobre el particular, o de la jurisprudencia del TS, sino también, desde el de la jurisprudencia constitucional, no hay duda alguna en que nos encontramos ante una relación de sujeción especial determinante de verdaderas sanciones disciplinarias y no generales, habida cuenta de que no todas las sanciones que se han intentado calificar como tales lo han sido finalmente en la jurisprudencia constitucional, como hemos observado atrás.

La respuesta es afirmativa y podemos afirmar que, de los criterios que utiliza la jurisprudencia del Tribunal Constitucional para justificar la presencia de relaciones especiales de sujeción, base de la potestad disciplinaria, el que mejor explica la de los alumnos universitarios y escolares es el primero de ellos, es decir el que habla de integración de ciertos ciudadanos en una institución preexistente que proyecta su «autoridad» sobre ellos, al margen de su condición común de ciudadanos, con adquisición por

93 STC 234/1991 (FJ 2, párrafo 9).

94 SSTC 234/1991, FJ 2, párrafo 6, y 188/2005, FJ 2.d. 
los mismos del status especifico de individuos sujetos a un poder público que no es el que, con carácter general, existe sobre el común de los ciudadanos ${ }^{95}$

También es aplicable al caso que nos ocupa la referencia a que, en tales relaciones, la determinación de las conductas identificables como antijurídicas en el seno de la institución es expresiva de la capacidad propia de autoordenación ${ }^{96} \mathrm{y}$ de la necesidad de garantizar el orden interno de la institución correspondiente ${ }^{97}$. Como, igualmente, es predicable de tal situación la alusión al "aseguramiento o la tutela de la organización [...], de forma tal que [...] pueda llevar a cabo de manera satisfactoria la función de servicio público que tiene constitucionalmente encomendada [...]"98.

Puede comprobarse que una razón semejante es la que ofrece la STS de 7 de junio de 1999, referente a sanciones de disciplina académica, cuando, después de destacar que el sancionado ha incumplido "obligaciones que son exigibles en la situación de sujeción especial en que se hallan los estudiantes matriculados en los centros universitarios", dice que "la sanción [...] (es) claramente reveladora del incumplimiento de obligaciones académicas conectadas con el cumplimiento de las funciones de la Universidad al servicio de la sociedad" 99 .

Sin embargo, no parece encajar aquí tanto el criterio de la jurisprudencia cnstitucional que alude a situaciones y relaciones administrativas donde la Constitución, o la ley de acuerdo con la Constitución, han impuesto límites en el disfrute de los derechos constitucionales, han modulado tales derechos constitucionales ${ }^{100}$, que explica mejor otro tipo de supuestos mencionados atrás.

B) Y comprobado, en los párrafos anteriores, que las sanciones impuestas a los alumnos universitarios por las Universidades encajan perfectamente dentro de la categoría de las sanciones propias de las relaciones de sujeción especial y no de las correspondientes a las relaciones de sujeción general, más por el primer criterio general de ésta que por el segundo de los citados, cabe todavía reforzar lo anterior trayendo a colación el pronunciamiento que el Tribunal Europeo de Derechos Humanos ha hecho sobre las mismas, en la misma línea de lo indicado.

Pues, dicho Tribunal, que se ha pronunciado expresamente sobre tal tipo de sanciones, en la Sentencia de 8 de diciembre de $2015^{101}$, ha calificado expresamente éstas como sanciones disciplinarias, contrapuestas a las penales, habida cuenta de que, en el caso enjuiciado, la sanción impuesta (exclusión de la Universidad por un período de tres años) por la conducta del sancionado invocada por la acusación (agredir verbalmente a dos empleados de la Universidad y de enviar correos electrónicos a otra persona y a otros profesores, con expresiones amenazadoras e insultantes, de naturaleza tal que dañan la dignidad y el prestigio de la institución universitaria) "tenía la intención

95 STC 2/1987, FJ 2, párrafo 2. Y otras posteriores, como la STC 27/2001, FJ 3.

STC 2/1987, FJ 2, párrafo 2.

STC 2/1987, FJ 4, párrafo 6.

STC 2/1987, FJ 2, párrafo 2. Y otras posteriores, como la STC 27/2001, FJ 3.

STS de 7 de junio de 1999 (RJ 1999\5018), FJ 2. 
manifiesta de mantener el orden y la disciplina dentro de la Universidad" y no era ni de las restrictivas de la libertad ni de las pecuniarias.

\subsection{La normativa aplicable en España y las exigencias de nuestro Ordenamiento jurídico para las nuevas normas en la materia. La normativa aplicable en Italia y Francia}

A) Como puede constatarse en diversas sentencias fechadas en el año 2017, actualmente se sigue aplicando el Reglamento de Disciplina Académica de los centros oficiales de Enseñanza Superior y de Enseñanza Técnica dependiente del Ministerio de Educación Nacional, aprobado por Decreto de 8 de septiembre de 1954, con leves modificaciones 0 adiciones introducidas por normas de años sucesivos ${ }^{102}$, pero anteriores a la Constitución de 1978. Pues, desde entonces no se ha aprobado un texto normativo que lo sustituya y la mayor parte de las Universidades no se ha arriesgado a aprobar un Reglamento propio, habida cuenta del carácter controvertido de la admisión de los reglamentos de tal tipo.

Hay que subrayar, en cualquier caso, que a pesar de la antigüedad del Reglamento de 1954 y de la obsolescencia de algunos de los tipos infractores, propios de la época del Franquismo, como han recordado algunas Sentencias ${ }^{103}$, sin embargo contemplaba ya en aquella época la aplicación de los principios generales del Derecho Penal y del Procesal Penal a las sanciones disciplinarias impuestas a los alumnos universitarios ${ }^{104}$. Y poseía su cobertura legal en el art. 101 de la Ley de Ordenación Universitaria de 29 de julio de 1943, que establecía una mínima regulación de la materia ${ }^{105}$.

Una vez instaurado el régimen actual de la Constitución de 1978, el art. 27.3 de la Ley Orgánica 11/1983, de Reforma Universitaria (LRU), dispuso que las Universidades, a propuesta del Consejo de Universidades, establecerían las normas que regulasen las responsabilidades de los estudiantes relativas al cumplimiento de sus obligaciones

102 Decreto de 13 de enero de 1956; Decreto de 5 de septiembre de 1958; Decreto 2456/1965, de 14 de agosto, del Ministerio de Educación Nacional; y Decreto 2457/1965, de 14 de agosto, sobre facultades disciplinarias de los rectores.

103 STSJ del País Vasco 559/2014, de 10 de diciembre (ROJ: STSJ PV 4083/2014), FJ 2. Resalta, así, que el tipo "las palabras o hechos indecorosos o cualesquiera actos que perturben notablemente el orden que debe existir en los establecimientos de enseñanza, dentro o fuera de las aulas", cuestionado por el recurrente, es realmente arcaico y descontextualizado y seguro que en aquel momento se refería a conductas propias de la moral social y costumbres de la época en aspectos muy remotos a lo que en este proceso se examina. Pero, no obstante, "el centro de gravedad del mismo ha de verse en línea con actos que sean notablemente perturbadores del orden académico, que es la vertiente más general que el precepto abarca". Y, en dicho sentido, considera de trascendencia al buen orden académico, las ofensas verbales a un Profesor; los enfrentamientos con unas compañeras; la exposición en lugar público de un escrito de denuncia al citado Profesor que contenía términos insultantes hacia su persona; y la falta de respeto a una diferente profesora dentro del aula con ocasión de la entrega de un examen.

104 Disposición Final y Transitoria $4^{\mathrm{a}}$.

105 La referencia a su desarrollo reglamentario, curiosamente, no se encuentra en su art. 101, donde se establece la regulación legal mínima, sino en el art. 41, letra g, al enumerar las competencias del Rector y también en el art. 59, letra g, al referirse a los derechos y obligaciones de los catedráticos numerarios, en el que se habla expresamente de un Reglamento de Disciplina Académica.

Y hay que recordar, asimismo, que el citado art. 101 de la Ley de 1943 quedó degradado a rango reglamentario, a raíz de la entrada en vigor de la Ley General de Educación de 1970, que, en su Disposición Final Cuarta, apartado uno, decía que "A partir de la publicación de la presente Ley, todas las disposiciones anteriores, cualquiera que fuere su rango, que venían regulando las materias objeto de la misma, regirán únicamente en cuanto fueren aplicables, como normas de carácter reglamentario hasta que vayan entrando en vigor las respectivas disposiciones que se dicten en ejercicio de esta Ley, en cuyo momento quedarán totalmente derogadas". 
académicas. Y algunos Estatutos de las Universidades basados en la LRU contemplaron la aprobación de un Reglamento de régimen disciplinario de la respectiva Universidad en el que se tipificasen las infracciones y las sanciones y se regulase el procedimiento para la imposición de éstas ${ }^{106}$. Pero la propuesta del Consejo de Universidades nunca se hizo efectiva, a pesar de que en el año 1992 se difundió en las Universidades un borrador de la misma que no llegó a ser aprobado. Entre otros motivos, se alegó por algunas Universidades frente a tal propuesta que la previsión de la LRU contradecía el principio de reserva de ley en materia sancionadora proclamado por el art. 25.1 de la Constitución, tal y como era interpretado por el Tribunal Constitucional en el ámbito disciplinario, a partir sobre todo de la STC 61/1990 ${ }^{107}$.

Y la Ley Orgánica 6/2001, de Universidades (LOU), en redacción no modificada por la Ley Orgánica 4/2007, dice simplemente, en su art. 46.2 que "los Estatutos y las normas de organización y funcionamiento desarrollarán [...] los deberes de los estudiantes, así como los mecanismos para su garantía"; por lo que, de nuevo, se está produciendo una remisión directa a las normas universitarias, que poseen rango reglamentario ${ }^{108}$.

Pero el mismo Gobierno de la Nación asumió que el régimen disciplinario de los alumnos universitarios exigía norma con rango de Ley. Así, la Disposición Adicional Segunda del Real Decreto 1791/2010, de 30 de diciembre, por el que se aprueba el Estatuto del Estudiante Universitario (bajo la rúbrica: regulación de los procedimientos administrativos sancionadores en el ámbito universitario), contemplaba que el Gobierno presentaría a las Cortes Generales, en el plazo de un año a partir de la entrada en vigor del presente Real Decreto, un proyecto de ley reguladora de la potestad disciplinaria, en donde se contendría la tipificación de infracciones, sanciones y medidas complementarias del régimen sancionador para los estudiantes universitarios de acuerdo con el principio de proporcionalidad. Y se añadía que, de igual modo, en dicho proyecto de ley, se procedería a la adaptación de los principios del procedimiento administrativo sancionador a las especificidades del ámbito universitario, de manera que garantizase los derechos de defensa del estudiante y la eficacia en el desarrollo del procedimiento.

Hubo un Anteproyecto de ley redactado por una ponencia Técnica de administrativistas que culminó sus trabajos en septiembre de 2011, pero no llegó a ser aprobado en las Cortes Generales ${ }^{109}$.

106 J. PEMÁN GAVÍN (1994, ps. 439-440) así lo destaca, aludiendo a algunos de ellos y a los órganos previstos para su elaboración y aprobación.

107 Ese fue el caso del Informe enviado por la Universidad de Alicante al Consejo de Universidades, del que fui redactor junto al profesor R. MARTÍN MATEO.

J. PEMÁN GAVÍN, por su parte (1994, p. 437, nota 6), ha indicado que los intentos producidos en el seno del Consejo de Universidades para aprobar la citada propuesta quedaron paralizados por la duda de inconstitucionalidad que pesaba sobre el artículo 27.3 LRU.

108 Así lo consideran también J.M. SOUVIRÓN MORENILLA y F. PALENCIA HERREJÓN (2002, p. 423), que subrayan que es el precepto de la LOU paralelo al de la LRU, dado que, en la garantía del cumplimiento de los deberes a la que alude, podría incluirse sin duda la oportuna normativa de cada Universidad sobre el régimen disciplinario académico.

109 Según nos relata I. JIMÉNEZ SOTO (2015, p. 263, nota 6), dicha Comisión estaba integrada por J. V. González García, E. Gamero Casado, Joan Manuel Trayter Jiménez y él mismo. En tal artículo I. JIMÉNEZ SOTO nos narra también todas las iniciativas que en los últimos años se han producido para la aprobación de un texto normativo sustitutivo del Reglamento de 1954. 
Por lo tanto, como, hoy por hoy, dicha Ley no ha sido aprobada, el texto normativo que plantea menos dudas de compatibilidad con el principio de reserva de Ley es el citado Reglamento de Disciplina Académica de 1954 (por lo que después diremos), que es el que está siendo aplicado en la mayor parte de las Universidades públicas ${ }^{110}$, como hemos anticipado arriba. Sólo escasas Universidades han aprobado sus propios Reglamentos de disciplina académica del alumnado, invocando ser un mero desarrollo o complemento del Reglamento estatal de $1954^{111}$.

B) En Italia, se menciona expresamente en la doctrina científica las sanciones a los alumnos como sanciones disciplinarias impuestas a sujetos que se encuentran en una peculiar relación con la Administración, que se ha calificado de relación de supremacía especial ${ }^{112}$. Y muchas de sus Universidades cuentan actualmente con Reglamentos universitarios reguladores de esta materia, aprobados con invocación de dos textos normativos con rango de ley ${ }^{113}$, si bien, curiosamente, unos sólo mencionan uno de ellos y los otros el otro, pero no suelen aludir a los dos simultáneamente.

Estos dos textos normativos son el Real Decreto-Ley de 20 de junio de 1935, n. 1071, de modificaciones y actualizaciones al Texto Único de las normas sobre enseñanza superior de 1933 (concretamente, su artículo 16) ${ }^{114}$, por un lado, y la Ley 240/2010, de 30 de diciembre, por otro ${ }^{115}$.

Pero también hay Universidades que se remiten en esta materia directamente al Real Decreto-Ley de $1935^{116}$. E incluso hay Universidades que ni siquiera mencionan expre-

110 Sentencias de los últimos años recaídas, por ejemplo, en relación con la UNED, con la Universidad de Extremadura, con la Universidad de Alicante o con la Universidad del País Vasco, así lo muestran.

111 Este es el caso del Reglamento de régimen disciplinario de los estudiantes de la Universitat Pompeu Fabra, aprobado por Acuerdo de su Consejo de Gobierno de 18 de julio de 2012, que indica en su Preámbulo que la situación de antigüedad del Reglamento de 1954 "hace conveniente la aprobación de una regulación interna por parte de la Universidad, la cual, sin innovar el sistema de infracciones y sanciones contemplado en el Decreto de 8 de septiembre de 1954, complemente y adecue las previsiones del citado reglamento". Un examen del mismo denota que contiene una tipificación bastante detallada de infracciones y sanciones, que va claramente más allá del Reglamento de 1954, configurándose como un auténtico texto normativo sustitutivo del mismo.

También es el caso del Reglamento de régimen disciplinario de los estudiantes de la Universitat Rovira i Virgili, aprobado por Acuerdo del Consejo de Gobierno de tal Universidad de 18 de diciembre de 2013, que se expresa en su Preámbulo en términos semejantes al de la Universidad Pompeu Fabra. Pero, al menos, en la tipificación de las infracciones y sanciones se aparta menos de la redacción del Reglamento de 1954.

E igualmente sigue esta línea la "Normativa sobre conducta académica de la Universidad Rey Juan Carlos", aprobada por su Consejo de Gobierno de 28 de febrero de 2014, que, a partir de su art. 6, regula esta materia, invocando que, promulgado el Reglamento de 1954 antes de la Constitución, dicho Decreto debe ser interpretado y aplicado conforme a lo dispuesto en la normativa sobre conducta académica de 2014 que dicho texto recoge. El grado de detalle en la tipificación de infracciones y sanciones es desde luego bastante distante del referido Reglamento de 1954.

112 E. CASETTA (2011, p. 358).

113 Las citamos abajo (IAU de Venezia, Firenze, Bolonia).

114 Dicho Texto único es el aprobado por Real Decreto de 31 de agosto de 1933-XI, n. 1592. A su vez, el DecretoLey de 1935 citado fue convertido en ley por la Ley de 2 de enero de 1936, n. 73 (GU. de 1 de febrero de 1936, n. 26).

115 La denominación completa de la Ley es "normas por las que se aprueban las normas en materia de organización de las Universidades, del personal académico y selección, así como de delegación al Gobierno para incentivar la calidad y la eficiencia del sistema universitario" (Gazzetta Ufficiale n. 10 del 14 de enero de 2011 Suplemento Ordinario n. 11).

116 Es el caso de la Università della Sapienza di Roma (https://www.uniroma1.it/it/node/23543). 
samente tal Ley, sino sólo la vulneración de normas legislativas, estatutarias y reglamentarias ${ }^{117}$.

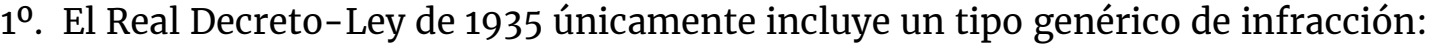
"hechos realizados por los estudiantes considerados lesivos de la dignidad y el honor", incluso fuera del círculo de instalaciones y establecimientos universitarios.

Y, en cuanto a las sanciones, recoge cuatro: a) amonestación; b) prohibición temporal de realizar uno o más cursos (en el sentido de estudios o actividades formativas $\left.\operatorname{concretos}^{118}\right)$; c) suspensión de uno o más exámenes; d) exclusión temporal de la Universidad con la consiguiente pérdida de las sesiones de examen ${ }^{119}$. Respecto de los órganos competentes para imponer las sanciones, según este Real Decreto-Ley, son el Rector o Director ${ }^{120}$ para las amonestaciones; la Junta de Facultad o Escuela, siguiendo un informe del Rector o Director, para la prohibición de realizar uno o más cursos y para la suspensión de uno o más exámenes; y el Senado Académico, siguiendo un informe del Rector o Director, cuando las infracciones anteriores se hayan realizado por alumnos de diversas Facultades o Escuelas o cuando se trate de la sanción más grave, de exclusión temporal de la Universidad con pérdida de las sesiones de examen.

Aunque tal Real Decreto-Ley también contemplaba que el Ministro de Educación podía sustituir a las autoridades académicas en la determinación y aplicación de las sanciones disciplinarias e incluso podía modificar la deliberación realizada en la materia por tales autoridades académicas, un Decreto-Ley de $1945^{121}$ derogó tal facultad de sustitución de la iniciativa de las autoridades académicas por el Ministro.

Por otra parte, el Decreto Ley de 1935 establece unas sumarias previsiones procedimentales. Respecto de la sanción de amonestación, lo único que se contempla es la audiencia in genere del alumno. Por lo que a las demás sanciones respecta, se requiere la notificación del acuerdo de incoación, al menos 10 días antes de la fecha fijada para la sesión de la Facultad o Consejo de la Escuela, a fin

117 Es el caso de la Università di Torino, que, en su Reglamento de estudiantes (Decreto rectoral 5099 de 05/08/2013) no regula ni infracciones ni sanciones, diciendo simplemente en su art. 19, bajo la rúbrica "Disciplina", que a los estudiantes que violen las normas legislativas, estatutarias y reglamentarias les serán aplicadas las sanciones administrativas. Después como infracciones se aplican las contempladas en el tipo genérico del art. 16 del Decreto-Ley de 1935 y las del Código de Comportamiento de la Universidad (Decreto rectoral n. 646/2016) y como sanciones las del Decreto-Ley de 1935.

118 Así lo interpreta el art. 54.7, letra b, del Reglamento interno en materia de carrera administrativa de los estudiantes de la Universidad "Instituto de Arquitectura de la Universidad de Venecia", aprobado por Decreto rectoral de 2 marzo 2015, n. 88.

119 Afecta a todos los centros y estudios universitarios no a cursos (estudios o actividades formativas) concretos, como es el caso de la sanción de la letra b.

Se estableció el plazo máximo de 3 años de exclusión por el art. 45 del Real Decreto de 4 de junio de 1938, n. 1269, sobre "Aprobación del Reglamento sobre estudiantes, títulos académicos, exámenes de Estado y asistencia escolar en las Universidades e Institutos Superiores".

120 De aquella época tenemos referencia a título de Director de Escuela que es sustituido por el de Rector. Es el caso de la Università Ca' Foscari di Venezia, que, fundada como Escuela Superior de Comercio, llega a impartir como tal estudios, no sólo económicos, sino también otros como jurídicos o lingüísticos y que se convierte en 1935 Universidad estatal, habiendo sido sustituido el año anterior el título de Director de la Escuela por el de Rector.

121 El Decreto-Ley del Lugarteniente del Rey de 5 de abril de 1945, n. 238. 
de que pueda presentar el inculpado su defensa por escrito o de palabra ante tales órganos. Y la decisión adoptada por la Junta de Facultad o Escuela es recurrible ante el Senado Académico. Después se dice que, salvo la amonestación, todas las demás sanciones se comunicarán a los padres de los alumnos y la sanción más grave, la de exclusión de la Universidad, a los otros centros de enseñanza superior del reino.

$2^{\circ}$. En cuanto a la Ley 240/2010 (la denominada reforma Gelmini), dice, en su artículo 2.2, letra $\mathrm{m}$, que las Universidades estatales modificarán sus estatutos con la observancia de una serie de vinculaciones y criterios directivos, entre los que incluye "la introducción de sanciones a aplicar en caso de violación del código ético".

El art. 2.4 dice que las Universidades que carezcan de dicho código adoptarán, en el plazo de 180 días desde la entrada en vigor de la Ley, un código ético de la comunidad universitaria, con cita expresa no sólo del personal docente investigador $\mathrm{y}$ del personal técnico-administrativo sino también de los estudiantes universitarios. Tal código determinará los valores fundamentales de la comunidad universitaria, promoverá el reconocimiento y el respeto de los derechos individuales, así como la aceptación de los deberes y responsabilidades en relación con la institución a la que pertenecen y dictarán las reglas de conducta en el ámbito de la Comunidad. Las normas estarán dirigidas a evitar toda forma de discriminación y de abuso, así como a regular los casos de conflicto de intereses o de propiedad intelectual.

Sobre las violaciones del código ético que no están bajo la competencia del Colegio de Disciplina (las de los alumnos no parecen estarlo) decidirá, a propuesta del Rector, el Senado Académico.

En el artículo 10 de la Ley se regula el Colegio de Disciplina y el procedimiento de actuación del mismo, que opera exclusivamente respecto del colectivo de profesores e investigadores ${ }^{122}$.

$3^{\circ}$. En el caso de los reglamentos universitarios que invocan el Decreto-Ley de 1935, como norma a desarrollar ${ }^{123}$, se evoca a su vez, para tal desarrollo su autonomía normativa ${ }^{124}$, que se reconoce a las Universidades en el art. 33 de la Constitución Italiana, dentro de los límites establecidos por las leyes estatales.

122 Está compuesta - según consigna dicho precepto- exclusivamente por profesores universitarios a tiempo completo e investigadores con relación de servicio indefinida a tiempo completo, de acuerdo con los procedimientos definidos por los estatutos. Y se prescribe como competente para llevar a cabo la fase instructora de los procedimientos disciplinarios y para emitir una propuesta final.

123 Así lo hace la Universidad de Firenze, en su Reglamento Disciplinario de los estudiantes, aprobado por Decreto rectoral de 7 de febrero de 2014, n. 78 - prot. n. 10480, en su art. 1. También la Universidad "Instituto de Arquitectura de la Universidad de Venecia", en relación con su art. 54.7, letra b, del Reglamento de 2 marzo 2015, donde regula las sanciones disciplinarias a los alumnos, en su documento titulado "Guida operativa al procedimento disciplinare nei confronti degli studenti dell'Universita' IUAV di Venezia".

124 Así lo hace también la Universidad "IAUV", en la citada "Guida operativa al procedimento disciplinare $[\ldots] "$. 
En el caso de los reglamentos universitarios que se apoyan en la Ley de $2010^{125}$, su habilitación pasa antes por la remisión que hace el art. 2.2, letra m, a los Estatutos de cada Universidad, cuando dice que las Universidades estatales modificarán sus estatutos para la introducción de las sanciones a aplicar en el caso de violaciones del código ético. Por tanto, a los efectos del cumplimiento del principio de reserva de ley, en ambos casos, podemos destacar que no hay una habilitación explícita al reglamento en el art. 16 del Real Decreto-Ley de 1935, pero sí en el artículo 2.2, letra m de la Ley 240/2010, para que los estatutos introduzcan sanciones a aplicar en caso de violación del código ético". Por otro lado, sí que se recoge un contenido mínimo en cuanto a las sanciones a imponer en el Real Decreto-Ley de 1935. Pero ni en tal RD Ley ni en la Ley 240/2010 se tipifican infracciones específicas, sino sólo el tipo genérico del art. 16 del RD Ley de 1935 ("hechos realizados por los estudiantes considerados lesivos de la dignidad y el honor") o las grandes pautas para la elaboración del Código Ético del art. 2.4 de la Ley 240/2010.

Por consiguiente, la remisión al Reglamento es bastante inespecífica. En cuanto a la predeterminación normativa de las infracciones y sanciones, exigida por el principio de tipicidad-taxatividad, se cumple en unos casos, a través de aquellos reglamentos universitarios que especifican tales infracciones y sanciones con cierto grado de detalle ${ }^{126}$. En otros, tan sólo se establece en el reglamento las normas de comportamiento y se indica que su vulneración se considerará infracción disciplinaria ${ }^{127}$. En otros, la infracción vendrá considerada porque la conducta sea contraria al tipo genérico del art.16 del RD Ley de 1935 ("hechos lesivos de la dignidad y el honor") ${ }^{128}$, donde el grado de precisión no es precisamente muy amplio. $\mathrm{Y}$, en otros, se combina la descripción de conductas consideradas infracciones tanto en el Reglamento de estudiantes como en el Reglamento del Código de Comportamiento ${ }^{129}$.

En cualquier caso, la vigencia del Decreto-Ley de 1935 como texto normativo de referencia directa o indirecta dota al sistema jurídico italiano de un grado importante de uniformidad en la materia tanto en cuanto a las sanciones enumeradas en aquél como a las infracciones, al girar sobre el tipo genérico de dicho Decreto-Ley.

125 Así lo hace la Universidad de Bolonia, en la propia cabecera de su Reglamento de estudiantes (aprobado por el Decreto rectoral n. 464 del 06/06/2013, objeto de modificaciones sucesivas, puesto al día con las modificaciones derivadas del Decreto rectoral 1554/2016 del 28.12.2016), en el que se regulan las sanciones disciplinarias en el art. 23 y ss.

126 Así, el art. 2 del Reglamento de la Universidad de Firenze de 2014 citado. El art. 53 del Reglamento de la Universidad "Instituto de Arquitectura de la Universidad de Venecia", ya lo recoge con un nivel menos preciso que el anterior.

127 Es el caso de la Università di Torino, que considera como infracciones las violaciones del Código de Comportamiento de la Universidad (Decreto rectoral n. 646/2016).

128 Es el caso de la Università della Sapienza di Roma (https://www.uniroma1.it/it/node/23543).

129 Es el caso de la Università di Bolonia. En el art. 23.1 del Reglamento de estudiantes de 2017 (aprobado por el Decreto rectoral n. 464 del 06/06/2013, objeto de modificaciones sucesivas, puesto al día con las modificaciones derivadas del Decreto rectoral 1554/2016 del 28.12.2016), dice que éstos deben observar comportamientos respetuosos de las leyes, de los reglamentos universitarios, de la libertad y de los derechos de todos los sujetos que desarrollan su actividad de trabajo o estudio dentro de las estructuras de la Universidad; que deben también abstenerse de dañar bienes de propiedad de la Universidad o de terceros que se encuentren temporalmente en ella, al igual que de comportamientos lesivos de la imagen o del decoro de la Universidad, incluso fuera de las estructuras universitarias. Y, en el Reglamento de su Código Ético y de Comportamiento (aprobado por Decreto rectoral n. 1408/14 del 01/10/2014), dedica el art. 25 a la responsabilidad de los estudiantes en el ámbito de su itinerario académico (en el que se mencionan el plagio o la copia de textos u otros comportamientos que pueden impedir una correcta valoración de la prueba). 
Sin embargo, desde el punto de vista organizativo, las soluciones recogidas en los distintos Reglamentos universitarios son más diversas.

Los hay que prevén la creación de una Comisión de Disciplina con facultades meramente instructoras ${ }^{130}$ y existen otros que contemplan tal Comisión con competencias resolutorias para la imposición de determinadas sanciones, sin perjuicio de las competencias propias del Rector o del Claustro (Senato Accademico) ${ }^{131}$.

$4^{\circ}$. El TEDH, en su Sentencia de 8 de diciembre de 2015, mencionada atrás, tuvo la oportunidad de enjuiciar el impreciso tipo del art. 16 del RDLey de 1935 (hechos perjudiciales para la dignidad y el honor de la institución universitaria), porque aparecía así recogido en el Reglamento de la Universidad de referencia (concretamente la Universidad de Nápoles), junto con la sanción que también era de las previstas en el art. 16 del RDLey de 1935 y llegó a la conclusión de que "estos textos eran accesibles $y,[. .$.$] redactados con la suficiente precisión para permitir que$ cada uno -que haga uso de consultores posiblemente preparados- pueda predecir, a un nivel razonable en las circunstancias del caso, las consecuencias que podrían derivarse de un acto específico" ${ }^{132}$.

C) En Francia, el reconocimiento de la potestad disciplinaria de las Universidades sobre los alumnos se realiza en una norma con rango de ley (el art. L 712-6-2 del Código de Educación ${ }^{133}$ ), a favor del Consejo Académico del establecimiento de enseñanza superior constituido en sección disciplinaria.

$1^{\mathrm{o}}$. Las infracciones se especifican en un precepto con rango reglamentario (el art. R 712-10 del Código de Educación ${ }^{134}$ ), aunque de algunas de ellas pueda localizarse

130 Es el caso del Reglamento interno en materia de carrera administrativa de los estudiantes de la Universidad "Instituto de Arquitectura de la Universidad de Venecia" de 2015, arriba mencionado.

Contempla una Comisión de Disciplina nombrada por el Senado Académico, a propuesta del Rector y de la que será miembro de pleno derecho el presidente del Senado de los estudiantes o su delegado (art. 53.5). Su cometido es iniciar el examen de los hechos atinentes a las infracciones sancionables por el Senado Académico, una vez que le han sido transmitidos por parte del Rector (art. 53.5). Y, tras la instrucción del procedimiento, realizará una propuesta de sanción al Senado, de la que éste se puede separar de forma motivada (art. 53.8).

Las sanciones de competencia del Senado Académico son todas salvo la de amonestación escrita (art. 53.8), que corresponde al Rector (art. 53.8, en relación con el art. 53.5).

131 Es el caso del Reglamento de la Universidad de Firenze de 2014 citado.

La Comisión de Disciplina se compone de dos profesores numerarios y un estudiante designado entre aquellos elegidos en los órganos centrales con exclusión de los que componen el Senado Académico. Sus miembros son designados por el Senado Académico a propuesta del Rector (art. 5). Y tiene competencias resolutorias para imponer la sanción de prohibición temporal de una o más actividades formativas concretas y la sanción de suspensión de uno o dos exámenes, por un periodo no superior a 6 meses (art. 4.2).

Al Senado académico le corresponde la competencia para imponer la sanción de exclusión temporal de la Universidad con la consiguiente pérdida de las distintas convocatorias de examen durante ese período (art. 4.2). Y el Rector tiene la competencia exclusiva para la imposición de la sanción de amonestación verbal (arts. 4.2 y 9), pero también le corresponde la iniciación del procedimiento disciplinario en relación con las otras sanciones, tras recibir la noticia de los hechos que puedan configurar una infracción disciplinaria (art. 6) y la fase instructora de los mismos, con posibilidad de decisión del archivo de las actuaciones o de realizar la propuesta de sanción a la Comisión de Disciplina o al Senado Académico, según el tipo de sanción que hemos citado (arts. 7 y 8 ).

132 Recurso $\mathrm{n}^{0}$ 34376/13 (asunto Luigi Monaco contra Italia), parágrafo 78, donde cita, entre muchas otras, la Sentencia Sunday Times v. Reino Unido (n. 1, de 26 de abril de 1979, § 49, serie A n. 30).

133 Que ha sido modificado por el art. 53 de la Ley $\mathrm{n}^{0}$ 2014-873, de 4 de agosto.

134 Creado por el Decreto $\mathrm{n}^{0}$ 2013-756, de 19 de agosto 
su previsión anterior en normas con rango de ley, como es la Ley de 23 de diciembre de 1901 de represión de los fraudes en los exámenes y en los procesos selectivos competitivos (concours) ${ }^{135}$.

Dichas infracciones consisten en que el usuario de la Universidad sea autor o cómplice de: a) un fraude o intento de fraude en relación con una matrícula, una prueba de evaluación continua, un examen o un proceso selectivo competitivo (concours); b) Un hecho que pueda afectar al orden o al buen funcionamiento de la Universidad; y c) un fraude o intento de fraude cometido al matricularse en una institución privada de enseñanza superior cuando dicha matrícula abre el acceso a un examen público de enseñanza superior o un fraude o intento de fraude cometido en un establecimiento de enseñanza superior o en una Universidad, con motivo de un examen conducente a un título nacional.

$2^{\circ}$. Las sanciones disciplinarias a los alumnos se encuentran en otro precepto reglamentario (el art. R 811-11 del Código de Educación ${ }^{136}$ ), pero del mismo también puede hallarse antecedente en norma con rango de Ley (el art. 29.3 de la ley $\mathrm{n}^{0}{ }^{1984-}$ 52 , de 26 de enero sobre la enseñanza superior).

Las sanciones para los usuarios del servicio en general ${ }^{137}$ son: a) la simple advertencia (l'avertissement); b) la amonestación (le blâme); c) La exclusión del establecimiento por un máximo de cinco años. Esta sanción puede imponerse con prórroga si la exclusión no excede los dos años; d) la exclusión final del establecimiento; e) la exclusión de cualquier establecimiento público de enseñanza superior por un máximo de cinco años; y f) la exclusión definitiva de cualquier establecimiento público de enseñanza superior.

A ello se añade que cualquier sanción prevista en este artículo y pronunciada en el caso de fraude o intento de fraude cometido durante el proceso de matrícula invalidará la misma.

También se consigna que cualquier sanción prevista en este artículo y pronunciada en el caso de fraude o intento de fraude cometido en el transcurso de una prueba de evaluación continua, examen o proceso selectivo competitivo, implicará para el interesado la nulidad de la prueba correspondiente. Se considera que la persona en cuestión estuvo presente en la prueba sin haberla realizado. El órgano disciplinario decidirá si es apropiado pronunciar, además, con respecto a la persona afectada, la nulidad del grupo de pruebas o de la sesión de examen o del proceso selectivo competitivo.

Y se finaliza estableciendo que las sanciones de exclusión (la de la letra c, sin imposición de prórroga) implican además la imposibilidad de realizar matrículas en el o los establecimientos públicos que imparten formación posterior al bachillerato y de realizar exámenes en tales formaciones.

135 Dice esta Ley, en su art. 1, que "cualquier fraude cometido en exámenes y concursos públicos con el propósito de ingresar a una Administración pública o la adquisición de un título emitido por el Estado constituye un delito". Y añade, en su art. 5, que "la acción pública no excluye la acción disciplinaria en todos los casos donde la ley lo estipule".

136 Creado por el Decreto $n^{0}$ 2013-756, de 19 de agosto.

137 Porque, en el artículo siguiente (R 811-12), se establece alguna especialidad para usuarios de estudios realizados a la vez en centros hospitalarios y universitarios. 
$3^{\circ}$. Así pues, la regulación es uniforme para todas las Universidades francesas. Los Reglamentos de Régimen Interno de algunas Universidades, al mencionar el régimen disciplinario en las mismas, lo que hacen en realidad es remitirse a las normas de carácter estatal citadas ${ }^{138}$.

Puede decirse que el principio de tipicidad se cumple en cuanto a las infracciones con cierta precisión en unas (la del fraude en la matriculación y en las pruebas de evaluación), pero con recurso a tipos demasiado amplios en otras (hechos que alteren el orden o el buen funcionamiento de la Universidad) y que se satisface bastante bien en cuanto a las sanciones, por ser su elenco bastante preciso.

Respecto al principio de reserva de Ley, como hemos visto, la tipificación actual tiene rango reglamentario, aunque tanto en las sanciones, como en parte de las infracciones (la del fraude en la matriculación y en las pruebas de evaluación), existe una regulación legal previa.

$4^{\circ}$. El órgano competente para ejercer la potestad disciplinaria es, como hemos visto atrás, el Consejo Académico del establecimiento de enseñanza superior ${ }^{139}$ constituido en sección disciplinaria. Y se integra por dos "professeurs des universités" o personal asimilado (los equivalentes a Catedráticos de Universidad españoles); dos "maîtres de conférences" o personal asimilado (los equivalentes a nuestros Profesores Titulares"); dos representantes de personal que ejerce funciones docentes pertenecientes a otro cuerpo de funcionarios; y seis usuarios del servicio (o sea alumnos) titulares y seis usuarios del servicio suplentes ${ }^{140}$.

Los miembros de la sección disciplinaria son elegidos en el seno del Comité de Investigación y del Comité de la formación y de la vida universitaria del Consejo académico por y entre los representantes elegidos para éste ${ }^{1 / 4}$. El presidente de cada sección disciplinaria ha de ser "Professeur d'université" elegido por los profesores e investigadores de la sección disciplinaria por votación mayoritaria en dos rondas ${ }^{142}$. Y no puede serlo el Rector de la Universidad ${ }^{143}$, porque, además, en Francia, el Rector

138 Así, el Reglamento de régimen interior de la Universidad TOULOUSE III-Paul Sabatier, en su art. 29.6 y ss., con alguna precisión. También el Reglamento de régimen interior de la Universidad de París-Sorbona, en sus arts. $35-36$ y 38 y ss.

139 Fue creado por la Ley n ${ }^{0}$ 2013-660 sobre Educación Superior e Investigación, con reagrupación en el mismo de los miembros de la Comisión de Investigación (Commission de la recherche) y de la Comisión de Formación y de la Vida Universitaria (Commission de la formation et de la vie universitaire) y con recepción de una parte de las atribuciones previamente transferidas al Consejo Científico o al Consejo de Administración, así como otras nuevas misiones.

Entre sus competencias, destacan la de ser consultado para la emisión de recomendaciones sobre políticas de formación, investigación, difusión de la cultura científica, técnica e industrial; sobre políticas de documentación científica y técnica; y sobre todas las medidas destinadas a garantizar el ejercicio de la libertad académica y las libertades sindicales y políticas de los estudiantes.

Además, como estamos examinando ahora, a su sección disciplinaria se le encomienda el ejercicio de dicha potestad disciplinaria de profesores, investigadores y alumnos.

140 Art. R.712-14 del Código de Educación, modificado por el art. 9 del Decreto n²015-79 de 28 de enero de 2015 .

141 Art. R-712-15 del Código de Educación

142 Art. R-712-16 del Código de Educación.

143 Art. R-712-17 del Código de Educación. 
está sometido al régimen disciplinario que se aplica a los miembros de los cuerpos docentes de enseñanza superior ${ }^{144}$.

$5^{\circ}$. El procedimiento está regulado en el art. R 712-29 y ss. del Código de Educación (aprobado por Decreto $\mathrm{n}^{\circ}$ 2013-756 de 19 de agosto).

Se inicia el procedimiento con una carta dirigida al Presidente de la sección disciplinaria del Consejo Académico, en la que se indica el nombre, la dirección y la calidad de las personas imputadas, así como los hechos que se les reprochan. $Y$ ha de ir acompañada de todas las pruebas justificativas ${ }^{145}$.

Se enviará certificada una copia de la carta, con acuse de recibo, por el Presidente de la sección disciplinaria, a cada persona imputada. En el caso de los menores, también se enviará una copia a las personas que ejerzan la patria potestad o la tutela de los mismos. E informará a las partes interesadas que pueden ser asistidas por un asesor de su elección (abogado, por ejemplo) y que pueden conocer el expediente durante la investigación.

A continuación, se designará por el presidente de la sección disciplinaria, para cada caso, una comisión instructora compuesta por dos miembros, uno de los cuales será nombrado secretario.

Tras la instrucción y audiencia del interesado, la comisión instructora tiene que remitir un informe al Presidente. Después se realizará una vista, en la que el secretario lee el Informe de la instrucción, se vuelve a oír a la parte imputada y se oye a los testigos, en su caso, y a las personas que promovieron el procedimiento o sus representantes y se confiere la última palabra al imputado. Finalmente se delibera y se adopta la decisión.

Y, por último, se contempla recurso administrativo ante el Consejo Nacional de Educación Superior e Investigación (CNESER) ${ }^{146}$, que será susceptible de recurso contencioso-administrativo ante el Consejo de Estado.

\subsection{El examen de la normativa española desde el prisma del principio de reserva de ley}

Laaplicación delprincipiodereserva deLey, nosplanteafundamentalmentelacompatibilidad con el mismo del Reglamento de Disciplina Académica de 1954; de los Reglamentos de disciplina académica de las Universidades calificados como actualización del Reglamento de Disciplina Académica de 1954; y de los Reglamentos universitarios de disciplina académica de cada Universidad eventualmente aprobados, en sustitución del Reglamento de 1954 y sin mediación de la ley anunciada en la Disposición Adicional Segunda del Real Decreto 1791/2010, sino sólo con la habilitación ofrecida por el art. 46.2 de la LOU.

A) En cuanto a la compatibilidad del Reglamento de Disciplina Académica de 1954 con el mismo, la misma se apoya en la doctrina del TC según la cual "no es posible admitir la reserva de Ley de manera retroactiva para considerar nulas e inaplicables disposiciones

144 Art.R-712-43 del Código de Educación, primer párrafo, último inciso. Resolución del Consejo de Estado. 4ème / 5ème SSR, 08/06/2015, 365205.

145 Art. R.712-30 del Código de Educación.

146 Art. R.712-43 del Código de Educación. 
reglamentarias respecto de las cuales esa exigencia formal no existía antes de la Constitución" ${ }^{147}$. Y éste es el caso de tal Reglamento, por ser anterior a la Constitución de 1978 y no existir reserva de ley en la materia en tal época.

B) La compatibilidad con dicho principio de los Reglamentos de disciplina académica de las Universidades calificados como actualización del Reglamento de Disciplina Académica de 1954, sin embargo, plantea mayores problemas.

Ya hemos resaltado atrás que, según la jurisprudencia del TC, los Reglamentos de actualización o de reiteración de preceptos de otros preconstitucionales son incompatibles con la reserva de Ley, en elámbito delas sanciones propias de las relaciones de sujeción general ${ }^{148}$. Pero también hemos destacado que, por el propio contenido del argumento y su contundencia (ese modus operandi "representaría convertir en buena medida en inoperante el principio de legalidad [...] con sólo reproducir, a través del tiempo, las normas reglamentarias sancionadoras preconstitucionales, manteniéndose así in aeternum, después de la Constitución), podemos decir que difícilmente podría negarse su aplicación a las relaciones de sujeción especial.

Y lo único que hemos visto admitido en la jurisprudencia constitucional para las relaciones de sujeción especial, también supra, es la integración de normas sancionadoras preconstitucionales con normas posteriores preconstitucionales 0 postconstitucionales que concreten los deberes y obligaciones cuyo incumplimiento se sanciona con la condición de que la integración no sea más que un reflejo casuístico de la formulación anterior que se desarrolla, en términos muy estrictos y que no se aparte del mismo bien jurídico protegido de la norma que desarrolla ${ }^{149}$.

Pero, a diferencia de otras normas preconstitucionales de otros ámbitos de relaciones de sujeción especial que tipificaban como infracción el incumplimiento de deberes, ello no aparece directamente previsto así en el Reglamento de Disciplina Académica de 1954, de tal modo que, por esa vía, no parecen admisibles Reglamentos universitarios postconstitucionales que se pretendan justificar en la concreción de los deberes cuyo incumplimiento se sanciona en el Reglamento de 1954.

C) Y la conformidad con la reserva de Ley de unos eventuales Reglamentos universitarios de disciplina académica de cada Universidad aprobados en sustitución del Reglamento de 1954 y sin mediación de la ley anunciada en la Disposición Adicional Segunda del Real Decreto 1791/2010, sólo con la habilitación ofrecida por el art. 46.2 de la LOU, es, sin duda, el punto clave de la controversia, ante la ausencia de normas con rango de Ley que hayan acometido la regulación en cuestión.

Pues, recordemos que la LOU no sólo autoriza a las "normas de organización y funcionamiento" de las Universidades (además de a los Estatutos) a regular los deberes del alumno, sino también los mecanismos para las garantías de éstos.

147 STC 69/1989, FJ 1, párrafo segundo, que cita como anteriores en la misma línea las SSTC 77/1983; 42/1987; 101/1988 y 29/1989. Pero también la STC 219/1989, FJ 2, párrafo 2, y STC 83/1990, FJ 2, párrafo cuarto.

148 SSTC 177/1992, FJ 3; 305/1993, FJ 7, párrafo tercero; 109/1994, FJ Único; y 52/2003, FJ 10. Y, en este sentido, ya M.J. GÓMEZ GARCÍA ha hecho hincapié en la imposibilidad de utilizar esta vía para los Reglamentos disciplinarios universitarios (2009, p. 614). 
Como se colige de lo expuesto arriba sobre la jurisprudencia constitucional atinente a las exigencias de la reserva de ley con respecto a las relaciones de sujeción especial, no hay una declaración incontrovertida de la jurisprudencia del TC para admitirlos o rechazarlos.

Serían admisibles con arreglo a lo declarado en la STC 219/1989, que aceptó, en el ámbito de las relaciones de sujeción especial, que la norma legal hiciese una remisión al reglamento vacía de todo contenido sancionador material propio ${ }^{150}$.

Pero presentaría dudas en contraste con la Sentencia 61/1990, destacada como superadora de la doctrina constitucional anterior en este sector, pues no lo deja aclarado con nitidez, ni lo han resuelto las sentencias atinentes a dicho tipo de relaciones posteriores a la misma.

Como ya hemos subrayado atrás, es cierto que afirma tal Sentencia que el principio constitucional prohíbe "la remisión al reglamento que haga posible una regulación independiente y no claramente subordinada a la Ley". Pero, en el mismo párrafo, contrapone el caso de remisión de la norma legal a normas reglamentarias, en el que en aquélla quedan «suficientemente determinados los elementos esenciales de la conducta antijurídica [...] y naturaleza y límites de las sanciones a imponer», al caso de las situaciones llamadas de sujeción especial, en las que lo que devendría lesivo del derecho fundamental del art. 25.1 CE sería una sanción carente de toda base legal151.

Por otra parte, si en las relaciones de sujeción especial se excluyesen las remisiones inespecíficas con habilitación legal previa, en realidad se estaría exigiendo el cumplimiento pleno y absoluto de la reserva de ley y entonces tendría poco sentido la invocación del Tribunal Constitucional en dicha Sentencia de que, en tales relaciones, cabe una adaptación de tal reserva de ley.

También hemos expuesto atrás que la STC 26/2005, con referencia a una situación que no se incluyó en las relaciones de sujeción especial (concesionario de expendeduría de tabaco), dice que, "con independencia de cómo se denomine la relación que une a la titular de la concesión con la Administración, no hay fundamento alguno para que la infracción por la que se sancionó a la recurrente carezca de la cobertura legal que, con carácter general, exige el art. 25.1 CE", añadiendo a continuación, con la conjunción "pues", que «la Ley sancionadora ha de contener los elementos esenciales de la conducta antijurídica y la naturaleza y límites de las sanciones a imponer" (FJ 5, letra c, párrafo segundo). Pero igualmente hemos precisado que las sentencias que cita para esta última conclusión no se refieren, ninguna de ellas, a relaciones de sujeción especial y ella misma tampoco, por lo que no dejaría de ser un pronunciamiento obiter dicta para dicho tipo de relaciones.

Y, además, hemos resaltado que sentencias posteriores a la 61/1990 y a la 26/200 $5^{152}$, que sí son específicas de las relaciones de sujeción especial, tampoco dejan resuelta

150 STC 219/1989, FJ 3, párrafo primero.

151 STC 61/1990, FJ 8, párrafo 1.

152 SSTC 188/2005, FJ 2.d; 229/2007, FJ 2, último párrafo; y 187/2015, FJ 4, párrafo sexto. La STC 81/2009 no enjuicia un supuesto de relación de sujeción especial, pero se refiere a ella para descartarla y dice exactamente lo mismo que las sentencias que acabamos de citar (FJ 5). 
la cuestión, pues no exigen que la Ley sancionadora haya de contener los elementos esenciales citados, sino que lo único que dicen es que tampoco respecto de las relaciones de sujeción especial goza la Administración de un poder normativo carente de habilitación legal, aunque ésta pueda otorgarse en términos que no serían aceptables sin el supuesto de esa especial relación. Y lo lógico es que, si realmente se hubiese consagrado, en la jurisprudencia constitucional, también para este tipo de relaciones, la exigencia de que la Ley sancionadora hubiese de contener los elementos esenciales de la conducta antijurídica y la naturaleza y límites de las sanciones a imponer, se hubiese reproducido en tales sentencias y no se ha hecho.

Porque, a su vez, como también hemos hecho notar supra, la prueba de que no existe hoy por hoy un criterio nítido en la jurisprudencia constitucional sobre tal cuestión son las Sentencias del Tribunal Supremo que se manifiestan en los dos sentidos de la disyuntiva ${ }^{153}$.

a) En este orden de cosas, en un planteamiento de lege data, no podría ser considerado, en principio, como fruto de una interpretación descabellada o temeraria, un Reglamento universitario sustitutivo del de 1954, sobre la base de exigir sólo la habilitación legal del art. 46.2 de la LOU y no un contenido legal mínimo, por tratarse de una relación de sujeción especial, en la que no se admite la supresión del citado derecho fundamental a la legalidad sancionadora del art. 25.1 (en su vertiente de legalidad formal o reserva de Ley), pero sí su adaptación y que la habilitación legal, pueda otorgarse en términos que no serían aceptables sin el supuesto de esa especial relación ${ }^{154}$.

Y no consideramos aplicable aquí el criterio basado en la STC 132/2001 y concordantes ${ }^{155}$, según el cual se admiten reglamentos tipificadores de infracciones y de sanciones siempre y cuando la Ley haya establecido los criterios mínimos de antijuridicidad conforme a los cuales cada ente pueda establecer después sus tipos de infracciones y siempre y cuando la ley haya establecido la clase de sanciones para que después cada ente pueda fijar las propias dentro de dicha clase.

Tal criterio, que en su día invocamos como utilizable para el régimen disciplinario de los alumnos universitarios ${ }^{156}$ y que también ha sido esgrimido por otros autores ${ }^{157}$ entendemos que no es aplicable, en estricto planteamiento lege data, por dos tipos

153 STS de 16 de marzo de 2001 (ROJ: STS 2124/2001), a favor de la posibilidad de la remisión inespecífica y STS de 15 de enero de 2009 (RJ 2009\469), a favor de la exigencia de la regulación legal mínima de los aspectos esenciales de las infracciones y sanciones.

154 Esto es lo que concluyó A. NIETO GARCÍA (1999, ps. 542-544), bajo el ámbito de aplicación de la LRU (Ley Orgánica 11/1983), sin citar por cierto ninguna Sentencia del TC., resaltando que, al tratarse de una relación de sujeción especial, bastaba con la cobertura legal que daba tal Ley a los Reglamentos universitarios, aunque no estableciese un contenido mínimo, sino una remisión legal en blanco; añadiendo que, en todo caso, sería muy difícil de justificar que tales reglamentos fuesen aprobados por órganos universitarios distintos del Claustro, que no contasen con la representatividad de éste.

155 SSTC 132/2001 (FJ 6, párrafo segundo) y 26/2005 (FJ 5, letra c, párrafo segundo), entre otras.

156 J.A. TARDÍO PATO (2003, p. 631).

157 J. TORNOS MAS (2010) y J.M. ALEGRE ÁVILA (2013). Aun invocando a estos autores, I. JIMÉNEZ SOTO (2015, ps. 285-286) lo que ha propuesto es una modificación puntual del art. 46 de la LOU que tuviera en cuenta el procedimiento disciplinario, las infracciones y las sanciones muy graves, dejando la tipificación de las infracciones y sanciones graves a la legislación autonómica y las infracciones y sanciones leves a la normativa de cada Universidad. 
de razones. Primero, porque las sentencias que lo han recogido se refieren todas ellas a relaciones de supremacía general y no de supremacía especial ${ }^{158}$, por lo cual es lógico que exijan ese contenido legal mínimo, que no se impone explícitamente como exigible en las relaciones especiales de sujeción. Y, por otro lado, porque el carácter representativo de la población de los plenos de los entes locales a los que se refiere tal Sentencia, propios de entes de carácter territorial y que actúan para los fines generales de la población, no es equiparable al carácter representativo de los órganos universitarios como el claustro, que pertenecen a entes que no tiene carácter territorial y no persiguen los fines generales de la población, sino los fines específicos de su ámbito competencial.

b) Ahora bien, ya desde un planteamiento de lege ferenda, si hay que decantarse por una de las dos interpretaciones plasmadas en las diferentes sentencias del TS citadas, entendemos que ha de ser por la más garante de la reserva de Ley, pues, habiendo calificado la jurisprudencia constitucional la legalidad sancionadora del art.25.1 CE (con sus dos vertientes: formal o reserva de ley y material o tipicidad) como derecho subjetivo fundamental ${ }^{159}$, habrá que aplicar también la doctrina constitucional de dicha jurisprudencia según la cual, antes dos interpretaciones posibles, siempre habrá que optar por la más favorable a la eficacia de un derecho fundamental ${ }^{160}$.

Por eso, aparte de por no estar resuelto por la jurisprudencia constitucional de modo preciso, no es extraño que existan sentencias de órganos jurisdiccionales inferiores al TS que rechacen la aceptación de los citados Reglamentos universitarios sancionadores basados en la LOU, negando que la LOU haya establecido una auténtica habilitación legal al respecto ${ }^{161}$, a diferencia de otras normas con rango de Ley de sectores de relaciones de sujeción especial, como el de los reclusos en centros penitenciarios o el de los policías, que establecen o unos criterios mínimos de la regulación o una parte de la misma.

Se cita, por un lado, en estas sentencias, jurisprudencia del TC como la recogida en la STC 219/1989, en la que se admite la simple remisión del art. 5.i) de la Ley

158 La STC 26/2005, con referencia a otra situación que acaba no encuadrándose en las relaciones de sujeción especial (concesionario de expendeduría de tabaco), aunque parece referirse a ambos tipos de relaciones cuando dice "con independencia de cómo se denomine la relación que une a la titular de la concesión con la Administración, no hay fundamento alguno para que la infracción por la que se sancionó a la recurrente carezca de la cobertura legal que, con carácter general, exige el art. $25.1 \mathrm{CE}$ " (FJ 5, letra c, párrafo segundo), las sentencias que cita para la exigencia de que "la Ley sancionadora ha de contener los elementos esenciales de la conducta antijurídica y la naturaleza y límites de las sanciones a imponer" son todas atinentes a relaciones de supremacía general.

SSTC 42/1987, FJ. 1, primer párrafo; 77/1983, FJ. 2, párrafo tercero; y 61/1990, FJ. 7, párrafo tercero

160 El principio de necesidad de interpretar siempre las normas del Ordenamiento Jurídico del modo más favorable a la eficacia de los derechos fundamentales ha sido proclamado por el TC en numerosas ocasiones, en su jurisprudencia (SSTC 159/1986, FJ 8, párrafo 5; 219/1988, FJ 3, párrafo 4; 177/2002, FJ 3,; 40/2003, FJ 2, letra b, párrafo 3; 192/2012, FJ 6, párrafos 9 y 13; 191/2013, FJ 3, párrafo segundo; 201/2014, FJ 3, párrafo 3; 1/2015, FJ 3, párrafo 3; y 23/2015, FJ 3, párrafo 4, entre otras).

161 Dice la STSJ 230/2015 de 25 marzo, de la Comunidad de Madrid (JUR\2015\135648), que "la Ley Orgánica de Universidades no establece la menor base normativa de tipificación de infracciones y sanciones, ni siquiera de los principios que habrían de inspirar tipificaciones reglamentarias" (FJ Segundo, párrafo 22). Rechazó la compatibilidad con el principio de reserva de ley de la sanción impuesta basada en la tipificación de infracciones y sanciones de los Estatutos de los Colegios Mayores de Fundación Directa de la Universidad Complutense de Madrid de 26 de mayo de 1987, que se pretendió apoyar no sólo en desarrollo de la LOU, sino también en desarrollo del Reglamento de Disciplina Académica de 1954 
2/1974, de Colegios Profesionales a la autoridad colegial corporativa vacía de todo contenido sancionador material propio, en la que hay que tener en cuanta apostillamos nosotros- que es anterior a la 61/1990, que es la que se invoca como determinante del cambio de criterio del TC respecto de las relaciones de sujeción especial.

Pero, por otro lado, se invoca cómo el art. 27 de la Ley Orgánica 2/1986, de Fuerzas y Cuerpos de Seguridad, al regular el régimen disciplinario de los funcionarios del Cuerpo Nacional de Policía, al menos tipifica específicamente las faltas muy graves (apartado 3), añadiendo después que las faltas graves y leves se determinarán reglamentariamente de conformidad con los criterios que a continuación expone (apartado 4).

Como también se alude a que, en el sector calificado por la STC 61/1990 como de relación de sujeción especial de gran intensidad, el de los reclusos en centros penitenciarios, los artículos 42 y ss. de la Ley Orgánica 1/1979, General Penitenciaria, aunque no tipifican las faltas disciplinarias muy graves, graves y leves, al menos sí que enuncian los principios de su tipificación (y las clases de sanciones -apostillamos nosotros-).

Y, puesto que la LOU no establece una regulación mínima al respecto y ha sido seguida después por el anuncio, en la Disposición Adicional Segunda del Real Decreto 1791/2010, de que se aprobará en esta materia una norma con rango de Ley, se concluye que, antes de tal regulación legal, los Reglamentos universitarios sustitutivos del Reglamento de 1954 vulnerarían el principio de reserva de Ley ${ }^{162}$.

Y otro argumento a favor de la regulación de un contenido mínimo con rango de Ley es que de ese modo, en un ámbito excepcional como es el sancionador ${ }^{163}$, que además puede afectar negativamente, aun de modo justificado, al derecho fundamental a la educación (como la pérdida de la matrícula y de las asignaturas aprobadas y no digamos de la prohibición de matricularse en centros docentes, que aparece en varias de las sanciones del Reglamento de 1954), se asegura mejor la igualdad de los alumnos universitarios de las distintas Universidades.

Porque, a su vez, siendo la razón de ser de la autonomía universitaria la garantía de la libertad académica (de la libertad de enseñanza, estudio e investigación) frente a injerencias externas ${ }^{164}$, ¿qué sentido tiene que las infracciones y sanciones y las garantías en su imposición sean distintas en las diferentes Universidades públicas españolas y sus alumnos?

Y, además, al afectar al derecho fundamental a la educación del art. 27 de la Constitución, tiene que existir una normativa estatal en virtud del art. 149.1.30 ("normas básicas para el desarrollo del artículo 27 de la Constitución, a fin de garantizar el cumplimiento de las obligaciones de los poderes públicos en esta materia") y 149.1.1 ("la regulación de las condiciones básicas que garanticen la

162 STSJ 230/2015 de 25 marzo, de la Comunidad de Madrid (JUR\2015\135648), en FJ Segundo, párrafos 12, 13 у 33.

163 STC 42/1987, FJ 2, párrafo tercero.

164 STC 26/1987, FJ 4. 
igualdad de todos los españoles en el ejercicio de los derechos y en el cumplimiento de los deberes constitucionales") ${ }^{165}$.

Nótese que ésta es ha sido claramente la interpretación oficial, como se muestra en que la regulación de los derechos y deberes de los alumnos se ha acometido por un Reglamento estatal (el Real Decreto 1791/2010) y en el mismo texto se ha previsto la regulación del régimen disciplinario por una Ley estatal. Aunque lo propio hubiese sido que, por lo atrás argumentado, se hubiese regulado todo (derechos, obligaciones y régimen disciplinario), de modo conjunto, en un texto con norma de Ley.

Sobre la base anterior, cabría una legislación de las CCAA en los términos reconocidos por la jurisprudencia constitucional para las competencias normativas sancionadoras de éstas. Pues les exige que, teniendo competencia en la materia (y ostentan competencia de legislación de desarrollo) y rango suficiente, no introduzcan tipos ni prevean sanciones que difieran, sin fundamento razonable, de los ya recogidos en la normativa válida para todo el territorio" ${ }^{166}$, "divergencias irrazonables y desproporcionadas al fin perseguido respecto del régimen jurídico aplicable en otras partes del territorio", con "una diferencia de trato sustancial o salto sancionador cualitativo que rompe la unidad en lo fundamental del esquema sancionatorio"167.

Aunque también ha admitido el TC la tipificación divergente por la legislación autonómica de infracciones por "la singularidad de la materia objeto de la norma autonómica", "al no existir una previsión sancionadora estatal con ese grado de especificidad" 168 . Y ha precisado que el art. 149.1.1 CE "ni representa una suerte de prohibición para el legislador autonómico de un trato divergente respecto de la legislación estatal, ni, en conexión con los arts. 14 y 138.2 CE, implica más que una exigencia de una igualdad en las posiciones jurídicas fundamentales" ${ }^{169}$.

En cualquier caso, este último criterio jurisprudencial podría invocarse, asimismo, para la normativa reglamentaria universitaria disciplinaria de desarrollo, en el sentido de que la misma tampoco podría suponer una diferencia de trato sustancial o salto sancionador cualitativo que rompiese la unidad en lo fundamental del esquema sancionador o que se apartase de la igualdad en las posiciones jurídicas fundamentales ${ }^{170}$.

165 Así lo ha sostenido ya J. PEMÁN GAVÍN (1994, p. 469, nota al pie 72).

166 STC 87/1985, FJ 8, párrafos quinto y ss. Declara inconstitucional, por ello, la sanción de clausura definitiva, no prevista en el ordenamiento estatal, junto a la clausura temporal sí prevista en éste.

167 STC 48/1988, FJ 25, párrafo tercero. Anula, así, por inconstitucionales determinadas sanciones como la destitución de los órganos de gobierno de las Cajas de Ahorro no contemplada en la legislación estatal, por considerar que supone. Y lo mismo afirma de la ampliación de la responsabilidad disciplinaria a las personas pertenecientes a cualquier órgano de gobierno de las Cajas, en vez de circunscribirla a los administradores y al Director General como preceptúa el ordenamiento estatal.

168 STC 136/1991 (FJ 2, párrafo tercero). Admite la tipificación divergente por la legislación catalana de infracciones relativas a sustancias que puedan generar dependencia por "la singularidad de la materia objeto de la norma autonómica", "al no existir una previsión sancionadora estatal con ese grado de especificidad".

169 STC 37/2002, FJ 15, párrafo cuarto. Y esto lleva al TC a admitir como constitucionales sanciones de la legislación autonómica por infracciones del personal al servicio de la Administración no contempladas en la legislación estatal en aquel momento, como traslado de puesto de trabajo a otro dentro de la misma localidad o la pérdida de uno a tres grados personales, así como un diferente plazo de prescripción.

170 Creemos que esto mismo es lo que apunta M.J. GÓMEZ GARCÍA (2009, p. 612). 


\section{4. Su contraste con las exigencias del principio de tipicidad-taxatividad}

La aplicación del principio de tipicidad y taxatividad plantea aquí, principalmente, las siguientes cuestiones: la admisión de infracciones tipificadas con empleo de conceptos jurídicos indeterminados; la exclusión de las descritas de modo tan abierto que permitan de hecho al órgano sancionador actuar con un excesivo arbitrio y que generen falta de certidumbre sobre lo que está realmente prohibido en calidad de infracción; y la interdicción de la interpretación analógica o extensiva in malam partem de las infracciones tipificadas.

A) Por un lado, podemos comprobar que la mayor parte de las infracciones del Reglamento de 1954 están tipificadas mediante conceptos jurídicos indeterminados y que, por lo tanto, poseen compatibilidad con el principio de tipicidad. Es el caso de "la injuria, ofensa o insubordinación contra las autoridades académicas o contra los Profesores"; "la ofensa grave, de palabra u obra, a compañero, funcionario y personal dependiente del Centro"; y también "cualesquiera actos que perturben notablemente el orden que debe existir en los establecimientos de enseñanza, dentro o fuera de las aulas".

B) Sin embargo, incluye algún tipo de infracción cuya compatibilidad con el principio de tipicidad es más discutible por estar tipificada con gran amplitud, de modo que puede llegar a producir incertidumbre y excesivo arbitrio del aplicador. Es el caso de "la falta de probidad" del art. 5.a.5 del Reglamento de 1954, que tiene su parangón con una infracción propia de los funcionarios calificada, en el art. 88 de la LFCE de $1964^{171}$, como "falta de probidad moral o material".

En tal tipo se aludía a actuaciones que afectaban negativamente a la honradez que debía de observarse en el ejercicio de sus tareas, con producción de menoscabo en el prestigio de la función que venía desarrollando su Administración y el colectivo al que pertenecía ${ }^{172}$. Y, precisamente, se destacó que, de toda la delimitación positiva y negativa de la falta de probidad que hacía nuestro Tribunal Supremo, se derivaba una gran imprecisión y que esto hacía muy difícil acceder a un concepto de falta de probidad tal como estaba siendo entendido en la aplicación cotidiana de nuestros preceptos disciplinarios ${ }^{173}$.

Pero la STC 50/1983 la ha considerado compatible con el art. 25 CE, como "concepto indeterminado para cuya concreción es procedente acudir [...] al contenido semántico del término" ${ }^{174}$. Dicho tipo significa, así - apostillo yo- , falta de honradez en el caso concreto en función de las circunstancias concurrentes y la gravedad de los hechos; lo cual es impreciso en su formulación previa, pero susceptible de precisión en su

171 Texto Articulado aprobado por Decreto 315/1964, de 7 de febrero.

172 Concretamente, PABLO GONZÁLEZ MARINAS (1972, ps. 77-78), después de analizar la jurisprudencia sobre la aplicación de tal tipo disciplinario dijo que podía llegarse a la siguiente formulación: "comisión por un funcionario de una serie de actos que afectan a la integridad y honradez que debe observarse en el desempeño de las funciones públicas, siempre que tal conducta, al producir con su notoriedad conocimiento o escándalo entre el público, implique menoscabo del prestigio de la Administración, del funcionario o de la función misma, aunque en dicha conducta no se aprecie mala fe o lucro del funcionario ni perjuicio económico para la Administración o los administrados". Téngase en cuenta que en el Diccionario de la Real Academia la probidad se define como "honradez".

173 PABLO GONZÁLEZ MARINAS (1973, p. 77).

174 FJ 2, último párrafo, donde invoca, además, dicha Sentencia que tal tipo aparece en una norma con rango legal (el Texto Articulado aprobado por Decreto 315/1964) citado. 
aplicación al caso concreto, en función de criterios lógicos, técnicos y de experiencia que permitan prever, por consiguiente, con suficiente seguridad, la naturaleza y las características esenciales de las conductas constitutivas de la infracción tipificada ${ }^{175}$.

Como, a su vez, cabe esgrimir el argumento de que, dada la ausencia de textos normativos sustitutivos del anciano Reglamento de Disciplina Académica, la anulación de este tipo tan amplio conllevaría, si no se aprobase urgentemente un nuevo texto en su sustitución, dejaría impunes conductas muy graves y nocivas para el sistema universitario y su función de evaluación de resultados del aprendizaje en dicho nivel educativo (como la superación de exámenes de asignaturas por algunos alumnos en virtud de transmisión de sus contenidos por un agente exterior mediante sofisticados equipos de telecomunicación ola sustracción delas preguntas de examen alos profesores, ya sea en papel, ya sea en fuentes informáticas), cuya sanción se está apoyando hoy en día en dicho tipo ${ }^{176}$. Argumento que es semejante al invocado por el TC en la Sentencia $219 / 1989$, en asunto disciplinario de miembros de colegios profesionales ${ }^{177}$.

Por otra parte, el Tribunal Supremo, además de haber recordado la admisión de tal tipo infractor por el TC en su Sentencia 50/1983, en relaciones de sujeción especial, añade que, como entendió la Sentencia de instancia recurrida, en el caso enjuiciado, tal tipo satisface la vertiente del principio de exigencia de certidumbre jurídica (lex certa), dado que "[...] para cualquier estudiante con experiencia normal es perfectamente reconocible que conductas como la que se dice en la relación de hechos probados de la resolución recurrida constituyen uno de los quebrantamientos más graves del deber de lealtad [...]. En definitiva, para cualquier estudiante normal [...] es perfectamente previsible que conductas tales [...] merecen el máximo reproche y, por tanto, la máxima sanción de las previstas por la norma" ${ }^{178}$.

Dicho de otro modo, se trata de un tipo abierto que, no obstante, puede satisfacer las exigencias sustanciales de uno de los fundamentos declarados por el TC del principio de tipicidad, cual es la certidumbre jurídica (lex certa) del principio constitucional de seguridad jurídica.

Es el mismo argumento que esgrimió más tarde el TEDH, en su Sentencia de 8 de diciembre de 2015, mencionada atrás, en relación con el impreciso tipo del art.16 del RD Ley de 1935 (hechos perjudiciales para la dignidad y el honor de la institución universitaria), tal y como aparecía recogido en el Reglamento de la Universidad de Nápoles, puesto que llegó a la conclusión de que "estos textos eran accesibles y, [...] redactados con la suficiente precisión para permitir que cada uno -que haga uso de consultores posiblemente preparados- pueda predecir, a un nivel razonable en las circunstancias del caso, las consecuencias que podrían derivarse de un acto específico"179.

175 STC 69/1989, FJ 1, párrafo quinto.

176 STS de 7 junio 1999 (RJ 1999\5018), FJ 1. STS de 15 de diciembre de 2000 (RJ 2000\9853), FJ 5.

177 Dice exactamente la STC 219/1989, FJ 6, párrafo final, lo siguiente: "Lo contrario supondría [...] que hasta tanto no se establezca de una manera expresa la correlación entre infracciones y conductas sancionables, quedarían impunes de responsabilidad administrativa disciplinaria las conductas ilícitas de los colegiados. Y a esta conclusión, que desapoderaría de una de sus funciones esenciales a los Colegios profesionales, no puede llevar el art. 25.1 de la Constitución".

178 STS de 15 de diciembre de 2000 (RJ 2000\9853), FJ 5.

179 Recurso $n^{0}$ 34376/13 (asunto Luigi Monaco contra Italia), parágrafo 78. 
Finalmente, lo mismo podríamos afirmar de la falta leve descrita como "cualesquiera otros hechos no comprendidos en los apartados anteriores que puedan causar perturbación en el orden o disciplina académicos". Es un tipo demasiado abierto e impreciso, pero al incluir los conceptos jurídicos indeterminados "perturbación en el orden o disciplina académicos", por un lado, y "hechos no comprendidos en los apartados anteriores", por otro, tal imprecisión inicial admite llegar a mayores cotas de precisión en su aplicación a los casos concretos, con ayuda de los criterios lógicos, técnicos y de experiencia que invoca la jurisprudencia constitucional; junto a un examen desde el prisma del principio de la proporcionalidad, que atiende aquí, primordialmente, a la gravedad de los hechos.

C) El problema es el de la exclusión de la interpretación analógica o extensiva in malam partem.

Desde luego, en virtud del mismo, deben quedar descartados tipos infractores generados totalmente ex novo por vía interpretativa a partir del tipificado. Pero deberían admitirse todas aquellas interpretaciones que, pudiéndose calificar como extensivas o analógicas, en un principio, en realidad, son fruto de la aplicación de los conceptos jurídicos indeterminados de los tipos existentes a los casos concretos o que se basen en el criterio utilizado por nuestro TS y el TEDH de capacidad de predicción por el imputado de que su acción era ilícita y sancionable según la legislación aplicable.

Porque una aplicación absolutamente cerrada de la proscripción de la interpretación analógica o extensiva in malam partem (como la que trasluce la STC 229/2007, al no admitir la reconducción del supuesto de "cobro de derechos arancelarios improcedentes", no recogido expresamente, al tipo infractor recogido de forma expresa de "cobro de derechos arancelarios procedentes pero en cuantía inadecuada") puede entrar en colisión la admisión de tipos amplios como falta de probidad o de conceptos jurídicos indeterminados.

\section{5. El principio non bis in idem y la potestad disciplinaria del alumnado.}

A) Como ya hemos recordado supra, la admisión en las relaciones especiales de sujeción de la dualidad de sanciones y procedimientos es una consecuencia natural de las exigencias del principio non bis in idem, en tanto en cuanto, para excluir la dualidad de sanciones, el mismo no sólo exige la identidad de hechos y sujetos, sino también la identidad de fundamento punitivo y, precisamente, en el ámbito de este tipo de relaciones y sus sanciones, se da esa diversidad de fundamentos sancionadores respecto del propio de las sanciones penales. Diferencia de fundamento que se identifica con el distinto interés jurídicamente protegido en cada caso, a la que se suma el requisito de que la sanción sea proporcionada a la diversa protección de intereses ${ }^{180}$.

El propio RDA de 1954 contempla la admisión de la dualidad de sanciones, en tanto en cuanto recoge como infracción grave disciplinaria la constitutiva de delito (art. 5.a. $5^{\mathrm{a}}$ ), lo que implica la previsión de que las conductas tipificadas como delito en el Código Penal y objeto de sanción penal, serán a su vez, si son cometidas por estudiantes universitarios, infracción disciplinaria grave objeto de sanción disciplinaria, si responde al interés jurídicamente protegido propio de la potestad disciplinaria.

180 SSTC 234/1991, FJ 2, párrafo 6, y 188/2005, FJ 2.d. 
Y así se ha admitido en sentencias del orden jurisdiccional contenciosoadministrativo, en las que se habían invocado condenas penales por los mismos hechos y sujetos.

a) En un supuesto, se declara por la sentencia contencioso-administrativa que no es incompatible la sanción penal con la disciplinaria, por entrar la conducta sancionada dentro de la infracción grave del art. $5^{\mathrm{o}}$.a $5^{\mathrm{a}}$ del Reglamento de Disciplina Académica de 1954 (falta de probidad), resaltando que el fundamento es distinto en ambas sanciones; dado que en el disciplinario viene representado por "la ausencia de honradez e integridad que cabe exigir a un estudiante universitario [...] que resulta contradictoria con quien se comporta violentamente en el interior de un recito académico, agrediendo a otra componente de la comunidad universitaria, y accede a un archivo pese a ser consciente de que está restringido a quienes pertenecen a la misma Facultad"181.

b) En otro supuesto, el sancionado disciplinariamente fue objeto de sentencia penal como autor criminalmente responsable de dos delitos contra la intimidad, con la concurrencia de la circunstancia eximente incompleta de alteración psíquica, por invasión, en los lavabos de la Facultad, de la intimidad de dos personas integrantes de la comunidad universitaria mediante grabación a través de un teléfono móvil. Iniciado el expediente disciplinario, se suspendió hasta que recayó la sentencia penal firme, momento en el que se reanudó la tramitación del expediente disciplinario, que culminó con dos sanciones por dos faltas graves: la de "falta de probidad" del art. 5.a). $5^{\mathrm{a}}$ del Reglamento de Disciplina Académica y "ofensa grave de palabra u obra a compañero, funcionarios y personal dependiente del Centro" del artículo 5.a). $3^{\mathrm{a}}$ del mismo Texto Legal.

$\mathrm{Y}$, ante la invocación de que se estaba vulnerando el principio non bis in idem, se contesta por la Sentencia contencioso-administrativa que existe una relación de supremacía entre el sancionado y la Administración y que el interés jurídicamente protegido en ambos ámbitos no es el mismo, pues mientras que en la jurisdicción penal el objeto de protección era el derecho a la intimidad de las personas que resultaron agraviadas por los hechos cometidos, con la sanción disciplinaria lo que se pretende restablecer es el orden y la convivencia en el campus universitario que, indudablemente, resultó afectado y degradado con el proceder del sancionado ${ }^{182}$.

B) Como resaltamos en el análisis general de la potestad disciplinaria desde la jurisprudencia constitucional, el principio non bis in idem posee también una vertiente procesal o procedimental, al prohibir dos procedimientos en supuestos en el que concurran las tres identidades y admitirlos cuando no concurren, como es el caso de la potestad disciplinaria en relación con la penal.

Y, por eso, el art. 17.1 del Reglamento de Disciplina Académica de 1954 dice que la instrucción de los expedientes a que se refiere este Reglamento y la imposición de las

181 STSJ de Galicia 259/2004, de 31 de marzo, Sección $1^{\text {a }}$ (JUR\2004\260143), FJ. 4, párrafo 7.

182 Sentencia del Juzgado de lo Contencioso-Administrativo $\mathrm{n}^{\circ} 2$ de Badajoz 160/2017, de 16 de octubre de 2017, $\mathrm{FJ}^{\circ}$. 
correcciones prescritas en el mismo son independientes de las que por los mismos hechos puedan efectuarse por las demás jurisdicciones competentes ${ }^{183}$.

Pero la jurisprudencia constitucional ha declarado con carácter general, a partir de la STC 77/1983, la admisión de que, "cuando el ordenamiento permite una dualidad de procedimientos, y en cada uno de ellos ha de producirse un enjuiciamiento y una calificación de unos mismos hechos, el enjuiciamiento y la calificación que en el plano jurídico puedan producirse, se hagan con independencia [...], pero que no pueda ocurrir lo mismo en lo que se refiere a la apreciación de los hechos, pues es claro que unos mismos hechos no pueden existir y dejar de existir para los órganos del Estado". A lo que ha añadido que "consecuencia de lo dicho, puesto en conexión con la regla de la subordinación de la actuación sancionadora de la Administración a la actuación de los Tribunales de justicia es que la primera, como con anterioridad se dijo, no puede actuar mientras no lo hayan hecho los segundos y deba en todo caso respetar, cuando actúe a posteriori, el planteamiento fáctico que aquéllos hayan realizado"184.

Esto es lo que recogió el derogado art. 7.3 del RD. 1398/1993 y hoy incluye el art. 77.4 de la Ley 39/2015, cuando afirma la vinculación de la Administración que tramita un procedimiento sancionador a los hechos declarados probados en virtud de resolución judicial penal firme.

Por eso, es lógico que determinados preceptos reguladores de sanciones disciplinarias impongan la suspensión del procedimiento hasta tanto no haya recaído sentencia o auto de sobreseimiento firmes en la causa penal ${ }^{185}$.

El art. 18 del RDA sólo dispone que "la autoridad competente [...] podrá suspender o demorar la instrucción de los expedientes administrativos hasta que formulen sus fallos los Tribunales".

Pero, en virtud de la referida jurisprudencia constitucional, no puede admitirse que quede a su criterio si suspende o no el procedimiento disciplinario, sino que deberá suspenderlo en todo caso, si inciden indicios de criminalidad o si ya se está tramitando el proceso penal correspondiente.

\section{6. El principio de proporcionalidad. El suspenso como sanción accesoria y como medida no sancionadora de evaluación del rendimiento académico de los alumnos. La ponderación de la sanción con derechos fundamentales eventualmente afectados como el derecho a la educación o la libertad de expresión.}

183 Dispone, además, el art.34 RDA que, "si en un Centro docente se cometiera algún hecho de los que sin caer bajo la acción académica están sujetos a la judicial, el Jefe de aquél dará parte al Juzgado para que proceda con arreglo a Derecho". Aquí, desde luego, a pesar de la confusa redacción empleada, tienen cabida los hechos que, por el doble fundamento e interés protegido, son objeto tanto de la potestad penal como de la disciplinaria, pues la parte penal no cae bajo la acción académica. Y resulta obligado comunicar a la jurisdicción penal los hechos perseguibles por tal jurisdicción.

184 STC 77/1983, FJ 4, párrafos primero y segundo, seguido por otras como la 2/2003 y 177/1999.

185 Así, el art. 94.3 del Estatuto básico del empleado público -EBEP- (hoy RDLegis. 5/2015), en relación con el procedimiento sancionador disciplinario del personal al servicio de las Administraciones públicas, si hay indicios fundados de criminalidad. Y el art. 415.2 de la Ley Orgánica 6/1985, del Poder Judicial, con respecto a procedimientos disciplinarios incoados a Jueces y Magistrados, indica que la incoación de un procedimiento penal no será obstáculo para la iniciación de un expediente disciplinario por los mismos hechos, pero no se dictará resolución en éste hasta tanto no haya recaído sentencia o auto de sobreseimiento firmes en la causa penal. 
Recordemos que el principio de proporcionalidad, en elámbito sancionador administrativo, implica la exigencia de "la adecuación entre la gravedad del hecho constitutivo de la infracción y la sanción aplicada" ${ }^{186}$, a lo que se añade que, además, deberá observar la debida idoneidad y necesidad ${ }^{187}$.

O sea, que se asume la interpretación y aplicación de dicho principio según el modelo alemán recogido por la jurisprudencia de nuestro TC desde la STC 66/1995 ${ }^{188}$, que exige la constatación de tres requisitos o condiciones (realización de tres juicios): a) juicio de idoneidad, es decir, si la medida en cuestión es susceptible de conseguir el objetivo propuesto; juicio de necesidad, o sea, si la medida es necesaria en el sentido de que no exista otra más moderada para la consecución de tal propósito con igual eficacia; y juicio de proporcionalidad en sentido estricto o ponderación, es decir, si la medida es ponderada o equilibrada, por derivarse de ella más beneficios o ventajas para el interés general que perjuicios sobre otros bienes o valores en conflicto.

Opera tanto en la determinación normativa del régimen sancionador como la imposición de sanciones y, dentro de éstas, tanto en la elección de las sanciones posibles como en la graduación de la sanción a aplicar, a cuyos efectos deberán considerarse los criterios recogido hoy en el art. 29.3 de la Ley 40/2015 ${ }^{189}$.

A) Lo normal es que se plantee en relación con la elección de la sanción, dentro de la escala, y del grado, dentro de la sanción.

a) Así se ha invocado la falta de proporcionalidad en el supuesto en el que la conducta infractora consistió en que dos alumnos penetraron de forma ilegal, sin la debida autorización, en las dependencias de un Departamento. Una vez dentro, se introdujeron en los despachos de los profesores, a pesar de que al menos uno de ellos estaba cerrado. Después, utilizaron los ejercicios allí depositados y en fase de corrección, así como otros elaborados por los profesores de la asignatura, para la confección de sus propios exámenes y, de ese modo, superaron las asignaturas mediante tales técnicas. Las sanciones impuestas fueron: a) expulsión a perpetuidad del Centro concreto de la Universidad, con prohibición de cursar en él las enseñanzas adscritas o que en el futuro pudieran adscribirse; b) Expulsión durante dos cursos de los Centros de la Universidad; y c) Anulación de las calificaciones obtenidas en las asignaturas implicadas en la correspondiente convocatoria.

La Sala de instancia destacó que, si conductas como ésta para cualquier estudiante con experiencia normal permitían prever el máximo reproche, la resolución que así lo

186 Así lo recogía el art. 131.3 de la Ley 30/1992 y lo reitera ahora el art. 29.3 de la Ley 40/2015.

187 Art. 29.3 de la Ley 40/2015.

188 La introducción de la aplicación del citado principio al modo alemán en la jurisprudencia de nuestro Tribunal Constitucional, a partir de la STC 66/1995, ha sido analizada por M. GONZÁLEZ BEILFUSS (2003, p. 54 y ss.). 189 Dichos criterios son: a) existencia de intencionalidad o grado de culpabilidad; b) continuidad o persistencia en la conducta (antes calificada como reiteración); c) la naturaleza de los perjuicios causados; y d) la reincidencia, por comisión en el plazo de un año de más de una infracción de la misma naturaleza, así declarado por resolución firme en vía administrativa.

189 Dichos criterios son: a) existencia de intencionalidad o grado de culpabilidad; b) continuidad o persistencia en la conducta (antes calificada como reiteración); c) la naturaleza de los perjuicios causados; y d) la reincidencia, por comisión en el plazo de un año de más de una infracción de la misma naturaleza, así declarado por resolución firme en vía administrativa. 
acordaba no podía considerarse desproporcionada. Y añadió que no parecía que pudiese hacerle tal reproche de falta de proporcionalidad, por determinar la pérdida de vínculo con el centro, quien antes había roto ese lazo de lealtad en que dicho vínculo se basaba.

La Sentencia del TS asumió tal respuesta y añadió que la Administración podía legítimamente optar entre las sanciones aplicables a las faltas disciplinarias muy graves y, si escogió las aquí aplicadas, lo fue en virtud de las especiales circunstancias que concurrían en los hechos, conductas gravemente incompatibles con la actitud académica exigible a unos estudiantes universitarios ${ }^{190}$.

Por otro lado, los sancionados invocaron que la anulación de los aprobados no aparecía como sanción en el Reglamento de 1954 (lo que más que infracción de la proporcionalidad sería de la tipicidad de las sanciones), a lo que respondió el TS que tal sanción está implícita en la (medida accesoria o sanción accesoria de) pérdida de matrícula y de curso que recoge el art. 12 de dicho Reglamento ${ }^{191}$; aspecto en el que abundaremos al final del presente epígrafe.

b) Otro supuesto en el que se invocó la infracción de dicho principio por no seleccionar la sanción adecuada fue aquel en el que la sancionada, con ocasión de estar desarrollando las pruebas escritas correspondientes a una asignatura, fue sorprendida por profesores que vigilaban el desarrollo del examen cuando utilizaba un aparato a través del cual, desde el exterior del aula, le era transmitido el contenido de las preguntas que aquélla debía exponer. Tales hechos se calificaron como constitutivos de una infracción prevista en el art. 5.a.5 del Reglamento de Disciplina Académica de 1954 y fueron objeto de la sanción de un año de expulsión temporal de todos los centros propios o adscritos a aquella Universidad, con arreglo a la sanción prevista en el art. 6.a.2 del citado Reglamento.

La respuesta del TS fue tan simple como decir que "la sanción no era desproporcionada, sino [...] adecuada a la gravedad de la infracción cometida, claramente reveladora del incumplimiento de obligaciones académicas conectadas con el cumplimiento de las funciones de la Universidad al servicio de la sociedad" ${ }^{192}$.

c) Y otro caso interesante, desde el punto de vista técnico, es aquel en el que a un alumno se le impuso la sanción de pérdida de matrícula de las asignaturas de los estudios en cuestión, en todas las convocatorias del curso académico 2014-2015, a pesar de tener aprobadas algunas de ellas, sobre la base de la sanción, prevista para las infracciones menos graves, en el art. 6.b.1 del Reglamento de Disciplina Académica de 1954: "Prohibición de examinarse de la totalidad o parte de las asignaturas en que se encuentre matriculado, en todas las convocatorias del año académico, con la consiguiente pérdida de los derechos de matrícula" ${ }^{193 .}$

190 STS de 15 de diciembre de 2000 (RJ 2000\9853), FJ 6.

191 STS de 15 de diciembre de 2000 (RJ 2000\9853), FJ 6. Pues dice exactamente el referido art. 12 que "las sanciones segunda y tercera del artículo sexto, apartado a), llevarán aneja, la pérdida de matrícula y de curso, con prohibición de trasladar el expediente académico, dentro del año escolar en que se cometió la falta corregida" y "la primera y segunda del apartado b), del mismo artículo, llevan aneja la prohibición de trasladar el expediente académico dentro del mismo curso".

192 STS de 7 junio 1999 (RJ 1999\5018), FJ 2, in fine.

193 Sentencia 102/2017, del Juzgado Central de lo Contencioso-Administrativo $\mathrm{n}^{0}$ 3, de 6 de septiembre 
La conducta del alumno sancionada consistió en enviar dos correos electrónicos a una profesora de tales estudios que le había suspendido en una asignatura, en los que se criticaba la actuación realizada por la Comisión de Revisiones del Departamento tachándola de corporativista y se vertían graves descalificaciones de dicha profesora por su actuación y a título personal. Y el tipo infractor invocado es el del art. 5.b.1 del Reglamento de 1954: "las palabras o hechos indecorosos o cualesquiera actos que perturben notablemente el orden que debe existir en los establecimientos de enseñanza, dentro o fuera de las aulas".

Ante la alegación de falta de proporcionalidad de la pérdida del aprobado en las asignaturas que había superado en dicho curso, la respuesta de la Sentencia contencioso- administrativa es, en primer término, que estamos ante una sanción prevista en un Reglamento vigente, como reconoce el sancionado. En segundo término, que es coherente que, al no haber podido finalizar el expediente disciplinario en el año académico durante el cual sucedieron los hechos, la sanción se aplique durante el mismo. En tercer lugar, que las matrículas de las asignaturas no podían entenderse derechos consolidados o adquiridos, en su caso, si no hasta que se resolviera el expediente disciplinario. Y, en cuarto lugar, que si la sanción se impone con posterioridad a la celebración de los exámenes del año académico, ésta se materializa con la pérdida de los derechos de matrícula y con ella la anulación de los resultados de exámenes realizados a su amparo, pero "ello no implica una retroactividad prohibida de la sanción, ya que dicha sanción estaba prevista antes de la realización del hecho sancionado" 194.

B) Si bien, también se ha invocado, en el ámbito de las sanciones disciplinarias del alumnado, en la elección del tipo infractor dentro de los próximos que presentan grado de semejanza pero están considerados como infracciones de distinta gravedad y, por tanto, son susceptibles de sanciones diferentes de distinta gravedad; lo que afecta a la determinación normativa del régimen sancionador y a la elección de las sanciones posibles.

Así, se ha planteado, en la elección respecto de los mismos hechos, entre el tipo del art. 5.a.3 (la ofensa grave, de palabra u obra, a compañero, funcionario y personal dependiente del Centro), considerado como infracción grave, y el tipo del art. 5.b.1 (las palabras o hechos indecorosos o cualesquiera actos que perturben notablemente el orden que debe existir en los establecimientos de enseñanza, dentro o fuera de las aulas), en el caso citado de invasión de la intimidad en los lavabos de la Facultad de dos personas integrantes de la comunidad universitaria mediante grabación a través de un teléfono móvil. Y la respuesta de la Sentencia ha sido que, por las características de la conducta del sancionado, ésta respondía más a la ofensa grave que a los meros hechos indecorosos, es decir a la infracción grave y no a la menos grave y que la sanción impuesta era totalmente proporcionada por ajustada a la gravedad de los hechos ${ }^{195}$.

194 FJ 10 de la citada Sentencia 102/2017, del Juzgado Central de lo Contencioso-Administrativo $\mathrm{n}^{0}$ 3, de 6 de septiembre. En ella se invocan para justificar lo último la STS 7/3/2002 y la SAN 22/10/2009.

195 Dice la Sentencia del Juzgado de lo Contencioso-Administrativo no 2 de Badajoz 160/2017, de 16 de octubre de 2017 (FJ 4, párrafo segundo): "el hecho de situar un teléfono móvil en un lavabo para tener acceso a lo más íntimo de las personas no puede despacharse con la consideración de un "hecho indecoroso", máxime cuando tales hechos tuvieron una evidente difusión que generó el lógico revuelo y que trascendió más allá del ámbito de la Facultad [...] e, incluso, del Campus Universitario. No parece, pues, a la vista de todo lo obrante al expediente 
C) Y hemos visto atrás que en los fundamentos de la demanda del recurso que dio lugar a la STS de 15 de diciembre de $2000^{196}$, los sancionados invocaron que la anulación de los aprobados no aparecía como sanción en el Reglamento de 1954 (lo que más que infracción de la proporcionalidad sería de la tipicidad de las sanciones), y que el TS respondió que tal sanción estaba implícita en la (medida accesoria o sanción accesoria de) pérdida de matrícula y de curso que recoge el art. 12 de dicho Reglamento.

Pero es que la calificación de suspenso en los supuestos de realización fraudulenta de exámenes académicos no tiene por qué ser considerado como una sanción administrativa disciplinaria o como una medida o sanción accesoria de la principal, como declara el TS sobre la base de la previsión del art. 12 del Reglamento de Disciplina Académica de 1954. Ello, por la sencilla razón de que, probado que el contenido de los exámenes no se ha expresado en virtud de los conocimientos de los alumnos, sino por esos otros medios fraudulentos, la evaluación del rendimiento no puede ser positiva, sino la negativa denominada suspenso. Así aparece en algunos Reglamentos de exámenes de las Universidades públicas que regulan la realización de éstos y las calificaciones académicas $^{197}$ y no el ejercicio de la potestad disciplinaria.

Puede ostentar, por tanto, tal suspenso la naturaleza de acto administrativo de calificación académica (en ejercicio de la potestad administrativa de evaluación del rendimiento académico, encomendada en nuestro sistema jurídico universitario a los profesores universitarios), sobre el juicio técnico de que el examinado no ha mostrado un rendimiento académico adecuado y no la de acto administrativo sancionador. Sería un acto de la actividad de ordenación, limitación o policía, en el que encuadran algunos autores dichas calificaciones ${ }^{198}$ y no de la actividad sancionadora, del mismo modo que se diferencian los actos administrativos derivados de la potestad de restauración de la legalidad urbanística (acto de derribo por construcción ilegal, con independencia de que concurra la culpa necesaria para que haya sanción) de los actos de la potestad sancionadora en el mismo ámbito.

D) La ponderación de la sanción con derechos fundamentales eventualmente afectados como educación o libertad de expresión.

administrativo, que se puedan minimizar los hechos y las consecuencias de los mismos". Y, por eso, finaliza diciendo: los hechos por los que ha sido sancionado el demandante tienen la suficiente entidad como para ser calificados de graves, siendo la sanción impuesta totalmente proporcionada y ajustada a la gravedad de los mismos. Las sanciones impuestas consistieron en la expulsión temporal por cinco años de todos los Centros de la Universidad e imposibilidad de matricularse en ninguna asignatura encuadrada en las distintas áreas de enseñanzas regladas de la misma durante el citado periodo, con efectos a partir de la fecha de la Resolución Rectoral.

196 STS de 15 de diciembre de 2000 (RJ 2000\9853), FJ 6.

197 Por ejemplo, la "Normativa de Evaluación de los Estudiantes de la Universidad Miguel Hernández de Elche", aprobado por su Consejo de Gobierno el 27 de julio de 2015 (Boletín Oficial de la UMH del 31 de julio), que así lo consigna, aunque no del mejor modo desde el punto de vista técnico, en los siguientes términos: "En las pruebas escritas u orales presenciales, el incumplimiento de las normas establecidas por el profesorado, así como la utilización de medios ilícitos o fraudulentos implicará la cancelación de la estudiante y la obtención de la calificación de o-suspenso en esa prueba, con independencia de cualquier otra responsabilidad en la que el estudiante pudiera incurrir".

198 Así, J.A. SANTAMARÍA PASTOR (2009, p. 269), que incluye las calificaciones académicas dentro de las comprobaciones como distintas a las autorizaciones y, dentro de aquéllas, en el grupo de las acreditaciones (verificación de requisitos de aptitud de personas), como distintas de las homologaciones (verificación de condiciones de idoneidad de objetos). 
Ya hemos visto atrás que, a partir de la STC 61/1990, se dice que, en las relaciones de sujeción especial, los derechos fundamentales y sus respectivos principios no pueden ser también restringidos o perder eficacia y virtualidad, porque no se puede relativizar un principio sin riesgo de suprimirlo. Pero sí que se admite que los requisitos derivados de tales derechos-principios (con referencia expresa a los requisitos del derecho del art.25.1 CE) "permitan una adaptación -nunca supresión- a los casos e hipótesis de relaciones Administración-administrado y en concordancia con la intensidad de la sujeción"199

En la imposición de sanciones disciplinarias a los alumnos universitarios, se ha manifestado su afección a derechos fundamentales como el de educación o el de libertad de expresión y también puede incidir eventualmente en otros. Pero, para la resolución de la posible tensión de la sanción disciplinaria con ellos, contamos con el juicio de ponderación ${ }^{200}$, propio del principio de proporcionalidad.

a) En cuanto al derecho a la educación, indiscutiblemente resulta afectado en el caso de aquellas sanciones que conllevan la pérdida de asistencia a clase, de los derechos de matrícula ya realizada (incluidos el derecho a examinarse o al aprobado obtenido en tales asignaturas) o del derecho a matricularse en centros universitarios, en el futuro. Otra cosa es que se considere lesionado.

En una primera Sentencia ${ }^{201}$, se alegó su lesión por una alumna que fue sancionada con un año de expulsión temporal de todos los centros propios o adscritos a una Universidad, al ser sorprendida en un examen escrito, cuando utilizaba un aparato a través del cual le era transmitido el contenido de las preguntas que aquélla debía exponer, desde el exterior del aula.

Y el TS declaró que la sanción impuesta no vulneraba el derecho a la educación reconocido en el art. 27 de la $\mathrm{CE}$, "pues la titularidad y goce de tal derecho es compatible con las atribuciones de la Administración educativa para restringir su disfrute a quien, con motivo de las pruebas encaminadas a verificar sus conocimientos (art. 27.1 y 3 de la LRU), incumple obligaciones que son exigibles en la situación de sujeción especial en que se hallan los estudiantes matriculados en los centros universitarios, siempre que tales sanciones sean congruentes al fin del mantenimiento de la disciplina académica y proporcionadas a la gravedad de la infracción, circunstancias que concurren en nuestro caso, en el que debe además ponderarse la limitada duración temporal de la sanción impuesta y la posibilidad que ha tenido la estudiante sancionada de cursar los estudios [...] en centros de alguna de las otras Universidades existentes incluso en la misma ciudad [...]". A lo que añade que la sanción no es desproporcionada sino que por el contrario la Sala la estima adecuada a la gravedad de la infracción cometida, claramente reveladora del incumplimiento de obligaciones académicas conectadas con el cumplimiento de las funciones de la Universidad al servicio de la sociedad.

\footnotetext{
199 STC 61/1990, FJ 8, párrafo 4.

200 Me remito a lo expuesto sobre la ponderación en mi libro sobre los Principios Generales del Derecho (2011, p. 243 y ss.).

201 STS de 7 de junio de 1999 (RJ 1999\5018), FJ 2
} 
Una segunda Sentencia ${ }^{202}$ enjuició la sanción impuesta a un alumno que se dejó suplantar en varios exámenes por otra persona que aprobó los exámenes por él, sin que tal alumno reclamase al publicarse las calificaciones. La sanción fue la de expulsión por tres años de los centros académicos del distrito universitario y la prohibición de examinarse de la totalidad de las asignaturas del curso académico, con la consiguiente pérdida de los derechos de matrícula. Y el alumno sancionado alegó la lesión de su derecho al libre desarrollo de la personalidad y del derecho a la educación, al impedirle continuar su formación docente.

La respuesta del TS fue que, aunque con gran frecuencia las sanciones impuestas en ejercicio del «ius puniendi» de las Administraciones Públicas afectan a derechos fundamentales, ello no supone per se, que sean contrarias a la Constitución. Por otro lado -añade- que, aunque las sanciones tengan por causa la comisión del hecho concreto tipificado, su contenido sancionador puede ser más amplio que el estricto aspecto en que se ha manifestado aquel hecho. Por eso no resulta jurídicamente inadmisible que, aunque la suplantación se haya acreditado con relación a una sola asignatura, sin embargo, el efecto sancionador se refleje en toda la vida académica del infractor, al constituir el hecho cometido un quebrantamiento sustancial a las mínimas exigencias de lealtad y buena fe en el sistema establecido de comprobación de los conocimientos adquiridos.

Finalmente, culmina diciendo que "el precepto constitucional invocado, según el cual la educación tendrá por objeto el pleno desarrollo de la personalidad humana, no abarca solamente la posibilidad de cursar asignaturas, sino también el aprendizaje de unas conductas de convivencia y de respeto a las normas establecidas, frente a cuyo desconocimiento son posibles reacciones sancionadoras como la sufrida por el recurrente".

Y una tercera Sentencia, esta vez de Sala de lo Contencioso-Administrativo de $\mathrm{TSJ}^{203}$, enjuició la sanción dela expulsión de la Facultad de Derecho de una Universidad, por un plazo de cinco años, por haber agredido a un Profesor en presencia de sus alumnos. Pero, además, lo hizo no de modo definitivo, sino en un momento todavía más crítico y complejo, que es el del otorgamiento o no de la medida cautelar de suspensión del acto recurrido en vía contencioso-administrativa, ante la invocación de que la ejecutividad de tal sanción podría hacer perder al recurso su finalidad legítima y que generaría unos perjuicios de muy difícil valoración, si después se estimara su pretensión anulatoria de la sanción.

Los perjuicios al recurrente consistían en que no podría terminar sus estudios en la Facultad en el año académico de la fecha, lo que afectaría a sus expectativas profesionales inmediatas y podía considerarse de difícil, sino imposible, valoración económica.

Los perjuicios al interés general invocados por la Universidad eran que la sanción perdería su sentido si el recurrente podía acabar sus estudios, pues, en ese caso, ya

202 STS de 7 de marzo de 2002 (RJ 2002\5077). 
no habría lugar a cumplir la sanción y la acción disciplinaria quedaría burlada, con la idea de que se podían cometer impunemente infracciones como la llevada a cabo por el recurrente.

El Juzgado de instancia otorgó la medida cautelar de suspensión de la ejecución de la sanción, pero la Sala del TSJ la revocó, por considerar que los perjuicios que la ejecución de la sanción podían irrogar al actor no eran de imposible reparación, por cuanto que, si la sentencia que finalmente recayese estimaba su recurso, nada impediría que pudiese terminar sus estudios en la Facultad, al ser la expulsión sólo temporal y porque, además, el actor tenía también la posibilidad de intentar terminar su carrera en otra Universidad de las existentes en la misma ciudad. A lo que añadió que ese retraso o compás de espera no podía contraponerse a los reales perjuicios que para los intereses generales representados por la Universidad demandada supondrían que una conducta como la observada por el actor quedase, finalmente, sin el reproche disciplinario que, de confirmarse, indudablemente merecía.

b) Ha sido invocada la lesión del derecho fundamental de libertad de expresión cuando la sanción se ha impuesto al alumno por insultos o descalificaciones a los profesores o a otros alumnos.

La Sentencia del TEDH de 8 de diciembre de 2015, atrás citada, se refirió a esta cuestión, puesto que al recurrente se le sancionó con la exclusión de la Universidad por un período de tres años, por la acusación de agredir verbalmente a dos empleados de la Universidad y de enviar correos electrónicos a otra persona y a otros profesores, con expresiones amenazadoras e insultantes. Una de las alegaciones de la demanda fue que con tal sanción se había lesionado su libertad de expresión, recogida en el art. 10 del $\mathrm{CEDH}^{204}$. La respuesta del TEDH fue, primero, recordar que el art. 10.2 del Convenio dispone que "el ejercicio de estas libertades [...], que entrañan deberes y responsabilidades, podrá ser sometido a ciertas [...] condiciones, restricciones o sanciones, previstas por la ley, que constituyan medidas necesarias, en una sociedad democrática, para [...] la defensa del orden y la prevención del delito [...] la protección de la reputación o de los derechos ajenos". Y, después, concluyó que el demandante fue castigado "para proteger la reputación y los derechos de los demás y motivado por la forma, juzgada inadmisible, en que se expresó el solicitante, y no por el hecho en sí de haber criticado a una institución" y "por haber ofendido la dignidad y el prestigio de ésta" ${ }^{205}$.

La conclusión es semejante en la STSJ de Murcia 100/2013, de 15 de febrero ${ }^{206}$, que, ante los insultos realizados por un alumno a otro alumno del órgano de representación de los estudiantes, por los gastos tan elevados realizados en unas jornadas durante la crisis económica de 2008, afirma que "el concepto de crítica no ampara las frases y expresiones ultrajantes $u$ ofensivas innecesarias para realizar una crítica ya que el art. 20,1 de la CE no reconoce un derecho al insulto, que sería incompatible con una norma fundamental" y mantiene la sanción, aunque la rebaja.

\footnotetext{
204 Recurso $\mathrm{n}^{0}$ 34376/13 (asunto Luigi Monaco contra Italia), parágrafo 75.

205 Parágrafo 80.

206 RJCA 2013\339, FJ 4.
} 
Y un planteamiento similar es que se realiza en el caso enjuiciado por la Sentencia 102/2017, del Juzgado Central de lo Contencioso-Administrativo $n^{\circ} 3$, de 6 de septiembre ${ }^{207}$, centrado en las descalificaciones por un alumno a una profesora recogidos en correos electrónicos de aquél a ésta, que fueron objeto de la sanción administrativa de pérdida de matrícula de las asignaturas de los estudios en cuestión, en todas las convocatorias del curso académico correspondiente, a pesar de tener aprobadas algunas de ellas.

Ante la invocación por el recurrente de la lesión de la libertad de expresión, contesta el Juzgado que no se ha producido tal lesión, porque el derecho fundamental no tiene carácter ilimitado y porque "el propio concepto de la libertad de expresión implica poner fuera de su ámbito propio todas aquellas expresiones o comportamientos que bien pueden tener una traducción penal o contrarios a la ética o a la deontología, a las costumbres sociales, o a los usos académicos normalmente observados en nuestro caso". "El ejercicio legítimo de su derecho a la discrepancia y a la revisión, como derecho reconocido por los estatutos docentes, y amparado también por la libertad de expresión, no guarda relación con el contenido de los mensajes dirigidos a la profesora en cuestión". "La libertad de expresión no puede abarcar expresiones injuriosas, en su caso calumniosas, o en su caso socialmente denigrantes, o desusadas en el ámbito académico, que constituyen verdaderas faltas de respeto o de decoro para con un profesor, siempre y cuando esas expresiones se profieren desde el ámbito o propio de sujeción especial de la disciplina académica [...]".

Añadela Sentenciaque "la Administración síha ponderado unas circunstancias de tal atenuación de la sanción pues ha calificado como falta «menos» grave por esas palabras bien indecorosas, bien perturbadoras notablemente del orden que debe existir en el ámbito académico, de acuerdo con el artículo 5 del reglamento disciplinario (y no como falta "grave», como caso de injuria u ofensa contra un profesor, artículo 5 a), entendiendo que el alumno carecía de antecedentes disciplinarios en su expediente académico, que había colaborado en el procedimiento y que «ha reconocido lo inadecuado de su proceder».

Y concluye diciendo que no ve "vulneración alguna del principio de proporcionalidad, puesto que parece que la finalidad de la normativa es prever que la comisión de ese tipo de infracciones tipificadas no resulte más liviano para el alumno infractor o más beneficioso infringir la normativa de disciplina académica que cumplirla efectivamente, y lo que la Administración ha pretendido con esta sanción es restablecer el orden académico quebrantado cuanto afecta, en los términos explicados, a los profesores intervinientes en la calificación de esa asignatura del demandante. Y, de acuerdo con los razonamientos antes expuestos, tampoco existe desproporción de la sanción impuesta, con sus consecuencias, que guardan congruencia con las regulaciones establecidas al respecto".

207 Sentencia 102/2017, del Juzgado Central de lo Contencioso-Administrativo $\mathrm{n}^{0}$ 3, de 6 de septiembre, FJ 11. El titular del Juzgado y autor de la Sentencia es ADOLFO SERRANO DE TRIANA. 


\subsection{Presunción de inocencia. La prueba de cargo sobre informes del profesor} universitario, las aportadas por los propios infractores con exclusión de la sanción o la reducción de la misma y las pruebas por presunciones. La prohibición de obtención de pruebas con violación de derechos fundamentales

A) Rememoremos que el principio de presunción de inocencia, proclamado en el art. 24.2 CE y recogido también en el art. 53.2.b de la Ley 39/2015, conlleva, según la STC 76/1990 (y posteriores en la misma línea) lo siguiente: a) que la carga de la prueba corresponde a quien acusa, sin que nadie está obligado a probar su propia inocencia; b) que la sanción esté basada en actos o medios probatorios de cargo que incriminen la conducta reprochada; c) que cualquier insuficiencia en el resultado de las pruebas practicadas, libremente valorado por el órgano sancionador, debe traducirse en un procedimiento absolutorio; d) y que, por ello, toda resolución sancionadora requiere a la par certeza de los hechos imputados obtenida mediante prueba de cargo y certeza del juicio de culpabilidad sobre esos mismos hechos, de manera que el art. 24.2 CE rechaza la responsabilidad presunta y la responsabilidad objetiva, así como la inversión de la carga de la prueba en relación al presupuesto fáctico de la sanción.

Por eso, en las normas procedimentales generales de la Ley 39/2015, se contempla que la propuesta de resolución no será necesaria cuando, en la instrucción del procedimiento, se ponga de manifiesto, entre otras circunstancias, que los hechos no resulten acreditados (art. 89.1, letra b). Al igual que prevé que tanto la propuesta de resolución (art. 89.3) como la resolución sancionadora (art. 90.1) incluyan la valoración de las pruebas practicadas, en especial aquellas que constituyan los fundamentos básicos de la decisión, con la eventual declaración de no existencia de infracción o no existencia de responsabilidad.

Dichos preceptos son aplicables plenamente a la potestad disciplinaria de los alumnos, al poseer el carácter de normas generales procedimentales aplicables en defecto de otras especiales y no existir en este caso normas especiales al respecto, ni normas que lo excluyan ${ }^{208}$.

B) Pues bien, a efectos de esa prueba de cargo necesaria para poder sancionar, aparecen aquí como importantes, aparte de los medios de prueba más generales (principalmente, la prueba documental, la testifical, la pericial y el interrogatorio de parte), la prueba aportada por algunos de los infractores al amparo del art. 62.4 de la referida Ley 39/2015, los atestados de los propios profesores basados en el art. 77.5 de la Ley 39/2015 y la prueba por presunciones del art. 386 de la Ley de Enjuiciamiento Civil.

208 Recuérdese que la Disposición Adicional Octava de la Ley 30/1992 excluía la aplicación de tal Ley a la potestad disciplinaria de las Administraciones Públicas respecto del personal a su servicio y de quienes estuviesen vinculados a ellas por una relación contractual. Pero las Leyes 39/2015 y 40/2015 no incluyen un precepto similar e incluso la Ley 40/2015 prevé en su art. 25.3 que las disposiciones del capítulo de los principios sancionadores sean extensivas al ejercicio por las Administraciones Públicas de su potestad disciplinaria respecto del personal a su servicio, cualquiera que sea la naturaleza jurídica de la relación de empleo.

Y téngase en cuenta, por otro lado, que el art. 2.2.c, dice que, a los efectos de dicha Ley, las Universidades públicas se regirán por su normativa específica y supletoriamente por las previsiones de la misma. Como, además, la Disposición Final y Transitoria $4^{\mathrm{a}}$ del Reglamento de Disciplina Académica de 1954 dispone que serán aplicables con carácter subsidiario a dicho Reglamento las disposiciones de carácter disciplinario para los funcionarios públicos y los principios generales del Derecho Penal y Procesal Penal. 
Pensemos, en una de las infracciones más comunes: la realización fraudulenta de exámenes, basada en la copia de otro examen o de materiales presentes en el aula (apuntes, libros, los resúmenes llamados chuletas) o en la derivada de medios de transmisión telemática.

a) Entre los medios clásicos, están, por un lado, la prueba documental (los exámenes implicados, los resúmenes utilizados para copiar, las fotografías de la colocación de los alumnos en el momento del examen o de los materiales que se han hallado junto al infractor, etc.). Por otro, la testifical (por ejemplo, de alumnos que han visto cómo copiaba otro o cómo transmitía oralmente las preguntas al operador en la fuente de transmisión para que le retrasmitiera las respuestas). Por otro, la pericial (cotejo de exámenes, sobre cuestiones derivadas de los modernos sistemas de transmisión telemática, etc.).Y, por otro, el propio interrogatorio de parte, con posible confesión del infractor o infractores.

b) Como novedad en el ámbito sancionador administrativo y posible incidencia en el ámbito que nos ocupa está, a los efectos de obtener la prueba de cargo, la prueba aportada por algunos de los infractores al amparo del art. 62.4 de la referida Ley $39 / 2015$.

Establece tal precepto que, si un denunciante que haya participado en la comisión de una infracción, existiendo otros infractores, sea el primero en aportar elementos de prueba que permitan iniciar el procedimiento o comprobar la infracción, siempre y cuando en el momento de aportarse aquellos no se disponga de elementos suficientes para ordenar la misma y se repare el perjuicio causado, se le eximirá de la sanción, si ha cesado en la participación de la infracción y no ha destruido elementos de prueba relacionados con el objeto de la denuncia.

Y, cuando no cumpliéndose alguna de las primeras condiciones anteriores, el denunciante facilite elementos de prueba que aporten un valor añadido significativo respecto de aquellos de los que se disponga, verá reducida su sanción.

Tal mecanismo, aunque no esté lejos de crítica, puede ser crucial a los efectos de obtener la prueba de cargo de la utilización de los sofisticados y avanzados métodos fraudulentos de transmisión telemática del contenido de los exámenes, habida cuenta de la ausencia en la mayor parte de las Universidades, si no en todas, de medidas preventivas para evitar tal fraude (inhibidores de frecuencia, arcos de detección de dispositivos electrónicos, etc.).

c) Otro medio de prueba en este ámbito es el de los atestados de los propios profesores basados en el art. 77.5 de la Ley 39/2015. Dice dicho precepto que "los documentos formalizados por los funcionarios a los que se reconoce la condición de autoridad y en los que, observándose los requisitos legales correspondientes, se recojan los hechos constatados por aquéllos harán prueba de éstos salvo que se acredite lo contrario".

Ya destacó el valor probatorio de cargo de este tipo de documentos, para romper la presunción de inocencia, la STC $761990^{209}$ y lo volvió a resaltar la STC 14/1997210. 
En el caso tomado como referencia y ejemplo, lo anterior viene representado por el Informe elaborado por el profesor afirmando que ha presenciado cómo el alumno estaba copiando de resúmenes o apuntes o de un teléfono móvil o cómo se oía junto al alumno el ruido de la transmisión (en sistemas antiguos) o cómo el alumno llevaba cableado visible en la parte próxima al cuello (también en sistemas antiguos y en defecto o complemento de las correspondientes fotografías o vídeos grabados, por ejemplo con la cámara del teléfono móvil) o sobre la colocación de los alumnos en el aula en el momento del examen (en defecto de fotografía que lo demuestre o de modo adicional a la misma).

La condición de autoridad está reconocida a los funcionarios docentes en diversas leyes autonómicas educativas (así, p. ej., la Ley 2/2010, de 15 de junio, de Autoridad del Profesor, de la Comunidad de Madrid o la Ley 3/2014, de 16 de abril, de autoridad del profesorado, de Castilla-León) y, con carácter general, sin distinción de etapas educativas, en el art. 550.1, segundo párrafo, del Código Penal, tras su modificación introducida por la Ley Orgánica 1/2015, que se refiere a "los funcionarios docentes que se hallen en el ejercicio de las funciones propias de su cargo, o con ocasión de ellas".

$\mathrm{Y}$, en cuanto a los requisitos legales correspondientes a tales documentos, cabe tener en cuenta lo consignado hoy en el art. 26 de la Ley 39/2015, que dice que "las Administraciones Públicas emitirán los documentos administrativos por escrito, a través de medios electrónicos, a menos que su naturaleza exija otra forma más adecuada de expresión y constancia". Y, a continuación, sólo refiere los requisitos para que los documentos electrónicos sean válidos y no los de los no electrónicos, pero de tal precepto se pueden extraer por analogía cuáles son tales requisitos en el caso de éstos: contener información de cualquier naturaleza; disponer de los datos de identificación que permitan su individualización; incorporar una referencia temporal del momento en que han sido emitidos; e incorporar las firmas que correspondan.

Por lo tanto, dicho Informe del profesor universitario que presenció los hechos y que ostenta la condición de autoridad en el ejercicio de sus funciones, con el cumplimiento de esos requisitos mínimos indicados, debe considerarse prueba de cargo suficiente, sin perjuicio de su mayor o menor carácter convincente, de la calidad de las pruebas presentadas de contrario y de las otras pruebas aportadas por tal profesor (los propios exámenes, como prueba documental, etc.).

d) La prueba por presunciones del art. 386 de la Ley de Enjuiciamiento Civil se define del siguiente modo: "a partir de un hecho admitido o probado, el tribunal podrá presumir la certeza, a los efectos del proceso, de otro hecho, si entre el admitido o demostrado y el presunto existe un enlace preciso y directo según las reglas del criterio humano". A ello se añade que "la sentencia en la que se aplique el párrafo anterior deberá incluir el razonamiento en virtud del cual el tribunal ha establecido la presunción". Y se completa diciendo que "el litigante perjudicado por ella siempre podrá practicar la prueba en contrario". 
Ha sido admitida en el ámbito sancionador administrativo por la jurisprudencia constitucional $^{211}$ y por la jurisprudencia de lo Contencioso-Administrativo del Tribunal Supremo ${ }^{212}$.

Pero es que, además, ha sido admitida expresamente en el ámbito de las sanciones disciplinarias a alumnos universitarios, en la STS de 7 de marzo de $2002^{213}$. En el caso enjuiciado por la misma, una persona compareció en varios exámenes suplantando la identidad de un alumno matriculado que fue objeto de sanción sobre la base de esta prueba por deducciones. La deducción consistió en que, si no reclamó el alumno beneficiado por la calificación, a pesar de que no había sido él quien había realizado el examen, es que estaba de acuerdo con la persona que se presentó al examen en su lugar. Y el Tribunal Supremo declaró que tal prueba era válida como prueba de cargo a efectos de romper la presunción de inocencia, porque "la actividad probatoria desemboca no en una hipótesis [...], sino en una deducción razonable, de pura lógica y de elemental sentido común.

Antes, había sido admitida implícitamente, en un supuesto semejante de suplantación de identidad en un examen, en el que, además, se probó que el que suplantaba la personalidad había recibido la transmisión del examen por vía telemática, en la STSJ de Extremadura 239/1998, de 16 de marzo ${ }^{214}$.

Como también fue admitida, expresamente, por la STSJ de Navarra 66/1996, de 21 de diciembre ${ }^{215}$, en un supuesto en el que el alumno sancionado entró al despacho del profesor de la asignatura, con la circunstancia de que sobre la mesa del profesor estaban las fotocopias y soluciones del examen previsto para el día siguiente, habida cuenta que el alumno ya tenía antecedentes admitidos por el mismo de copiar y de hacer los exámenes fuera del aula para su posterior introducción en la misma.

Y, asimismo, se adujo, explícitamente, en la STSJ de Madrid 1140/1999 de 10 de noviembre ${ }^{216}$, que enjuició la sanción al recurrente con la expulsión de la Universidad, por un año, con pérdida de matrícula de un año académico, por pretender introducir como examen un texto ya preparado. Destaca la Sentencia que queda desvirtuada la presunción de inocencia, aparte de por la prueba practicada, por la prueba por indicios, porque había dos textos de exámenes, uno completado y otro sólo iniciado; prueba pericial de que el papel no tenía la misma antigüedad ni el mismo sello y existían ciertas diferencias en la caligrafía, pese a que pertenecía a la misma persona; explicaciones un tanto contradictorias del recurrente sobre lo sucedido; y que la profesora que sorprendió al alumno expuso en su escrito inicial que había

211 SSTC 174/1985; 175/1985; y 229/1988.

212 En Sentencias tales como las SSTS de 23 de marzo de 2015 (casación 4422/2012), 16 de febrero de 2015 (dos sentencias con esta fecha dictadas en los recursos de casación 940/2012 y 4182/2012) y 6 de noviembre de 2013 (casación 2736/2010), así como las que en ésta se citan de 18 de noviembre de 1996, 28 de enero de 1999 y 6 de marzo de 2000. Y, además, en la más reciente STS de 28/9/2015 (ROJ: STS 4025/2015), FJ $2^{\circ}$, que invoca todas las demás.

213 STS de 7 de marzo de 2002 (RJ 2002\5077). En realidad, es fundamento jurídico de la sentencia recurrida que acepta la Sentencia del TS, en su FJ 1, tercer párrafo.

214 RJCA $\mid 1998 \backslash 986$, FJ 4.

215 RJCA\1996\2596, FJ 3.

216 RJCA $1999 \backslash 4876$, FJ 4. 
transcurrido breve tiempo desde que comenzó el examen cuando el alumno ya tenía un texto completo, lo que ratificó en su declaración posterior.

Es aplicable, por tanto, a nuestro entender, igualmente, en el caso de dos exámenes idénticos en los que ninguno de los dos alumnos ha denunciado que el otro le ha copiado, habida cuenta de que la copia de un examen de varias hojas en su integridad es prácticamente imposible que se realice sin la colaboración de ambos alumnos. Y también puede invocarse para el caso en que los que han entregado dichos exámenes idénticos estaban sentados en pupitres distantes y uno de ellos ha confesado que se le transmitió el contenido desde el exterior ${ }^{217}$.

C) La prohibición absoluta de obtener y utilizar pruebas con vulneración de derechos fundamentales se considera una implicación del derecho a la presunción de inocencia ${ }^{218}$. Puede entenderse, por tanto, lesivo del derecho a la presunción de inocencia la aportación como prueba de cargo, por ejemplo, de grabaciones de voz de una conversación por una persona que no estuviese presente en ésta para acreditar injurias u ofensas realizadas por un alumno; pero no si quien aporta tal prueba estuvo presente en dicha conversación ${ }^{219}$.

Y lo mismo puede considerarse de la aportación de correos electrónicos ajenos, pero no de los que se es parte, de modo que se ha admitido su aportación por el profesor a cuya cuenta iban dirigidos y que era el ofendido a través de los mismos ${ }^{220}$.

\subsection{Prescripción del ejercicio de la potestad, caducidad del procedimiento y caducidad impropia}

A) En cuanto a la prescripción del ejercicio de la potestad de sancionar y de la potestad para ejecutar las sanciones previamente impuestas, el Reglamento de disciplina académica de 1954 no hace referencia a los plazos de prescripción de las infracciones ni de las sanciones que tipifica.

Cuando el TS se ha enfrentado con esta cuestión, antes de la entrada en vigor de la Ley 30/1992, que es la primera ley administrativa que establece plazos de prescripción por defecto, ha declarado que procedía la aplicación del plazo de dos meses previsto

217 Estos supuestos se han verificado en la Universidad Miguel Hernández de Elche, pero no se ha iniciado hasta la fecha procedimiento sancionador alguno. Sólo se ha declarado el suspenso o no aprobado de los alumnos implicados, incluso con intervención, en uno de los casos, de la correspondiente comisión de revisión de exámenes, que ha ratificado el suspenso otorgado por el profesor.

218 SSTC 127/1996, FJ 3, párrafo tercero; 7/1998, FJ 5, párrafo segundo; 346/2006, FJ 5; 66/2007, FJ 6; y 161/216, FJ 1, párrafo tercero.

219 Pues es jurisprudencia del Tribunal Constitucional que la prueba de grabaciones sonoras, aunque no cuente con autorización judicial previa, no lesiona derechos fundamentales como el derecho a la intimidad o el derecho al secreto de las comunicaciones, cuando la misma se obtiene de conversaciones en las que está presente la persona que graba (SSTC 114/1984, FJ 7, párrafo 6, y 56/2003, FJ 3º , párrafo tercero y ss., entre otras).

220 Sentencia 102/2017, del Juzgado Central de lo Contencioso-Administrativo $\mathrm{n}^{0}$ 3, de 6 de septiembre, atrás citada. Recordemos que enjuicia la sanción a un alumno por enviar dos correos electrónicos a una profesora que le había suspendido en una asignatura, en los que se vertían graves descalificaciones de dicha profesora por su actuación y a título personal. Y el tipo infractor invocado fue el del art. 5.b.1 del Reglamento de 1954: "las palabras o hechos indecorosos o cualesquiera actos que perturben notablemente el orden que debe existir en los establecimientos de enseñanza, dentro o fuera de las aulas". 
para todas las infracciones administrativas que no tuviesen en su regulación específica otro plazo distinto de prescripción, que ya recogía la jurisprudencia consolidada de dicho Tribunal ${ }^{221}$.

Desde luego, a partir de la entrada en vigor de la Ley 30/1992 y su art. 132 donde se establecen esos plazos de prescripción por defecto, hay que entender aplicables los mismos al ámbito de la disciplina académica ${ }^{222}$. Y lo propio cabe mantener en la actualidad, puesto que el art. 30 de la Ley 40/2015 mantiene idéntico mecanismo y plazos. Como a idéntica solución se llegaría si se aplicasen los plazos de prescripción fijados en el Real Decreto Legislativo 5/2015, del Estatuto Básico del Empleado Público $(\text { art. 97) })^{223}$.

Una cuestión interpretativa que se plantea es que, mientras la Ley 40/2015 habla de infracciones y sanciones muy graves, graves y leves, el Reglamento de disciplina académica habla de infracciones y sanciones graves, menos graves y leves.

Consideramos que lo lógico es entender aplicables los plazos de las infracciones y sanciones muy graves de la ley 40/2015 a las infracciones y sanciones graves del Reglamento de 1954 y los plazos de infracciones y sanciones graves de la ley actual a las infracciones y sanciones menos graves del Reglamento citado, pues las escalas son equivalentes aunque con terminología diferente que debe ser objeto de su correspondiente correlación.

B) Por lo que a la caducidad del procedimiento respecta, no establece el Reglamento de disciplina académica un plazo máximo para resolver y notificar, pero sí que prescribe, en su Disposición final y transitoria $4^{\mathrm{a}}$, la aplicación subsidiaria al Reglamento en cuestión de las disposiciones de carácter disciplinario de la función pública.

Esto ha llevado ya, a algunas sentencias que se han pronunciado sobre el particular, a aplicar el plazo de 12 meses previsto por el artículo 69.1 de la Ley 24/2001 de 27 de diciembre, para el Real Decreto 33/1986, por el que se aprueba el Reglamento Disciplinario de los Funcionarios de la Administración del Estado, añadiéndolo para ello al anexo 1 de la Disposición adicional vigésima novena, de la Ley 14/2000 ${ }^{224}$.

221 Así, en la STS de 9 de julio de 2001 (RJ 2001\7772), FJ 3, se dice que sobre el tema existe jurisprudencia de la Sala tan consolidada que hace ociosa la cita de sentencias concretas, que parte de la Sentencia de la Sala Especial de Revisión de este Tribunal Supremo, de fecha 6 de abril de 1990 (RJ 1992\8440), en la que se acogió la tesis - confirmada en multitud de sentencias posteriores- del plazo único prescriptivo de dos meses para todas las infracciones administrativas que no tengan en su regulación específica otro plazo distinto de prescripción. En este sentido, por citar una de las últimas, cita la STS de 29 de marzo de 2001 (RJ 2001\4513), dictada en relación con un recurso de contenido muy similar al presente, interpuesto asimismo por la UNED.

222 Así lo hace la SAN de 16 de diciembre de 2003 (JUR 2004\132075), FJ 1.

223 D. CÁMARA DEL CASTILLO (2011, ps. 164-165) cita la SAN de 12 de octubre de 2007 (Ponente Francisco Díaz Fraile), que no he localizado, en la cual -relata el autor indicado-, se declaró la aplicabilidad de los plazos de prescripción de las infracciones de los funcionarios por la previsión de aplicación subsidiaria de su régimen que hace la Disposición Final y Transitoria $4^{\mathrm{a}}$ del Reglamento de Disciplina Académica de 1954.

Si bien, como indica tal autor (2011, p. 165), la distinción de criterio no tiene ya relevancia desde el momento en que la legislación de funcionarios estableces los mismos plazos de prescripción que los de la legislación procedimental administrativa.

224 Así, la Sentencia de la Audiencia Nacional (Contencioso, Sección $3^{\text {a }}$ ) de 9 de octubre de 2007 (ROJ: SAN 4277/2007), FJ 2.También, la STSJ de Murcia (Contencioso, Sección 2a) 100/2013, de 15 de febrero (RJCA 2013\339), FJ 1, que da por bueno el fundamento del órgano judicial de instancia que rechazó la caducidad del expediente del 
Entendemos que debe aplicarse dicho plazo y no en general por defecto de 3 meses establecido pon el actual art. 21.3 de la ley 39/2015, al preverse la aplicación supletoria citada.

Como tampoco tiene sentido ya plantearse la aplicación del plazo de 6 meses que llegó a ser impuesto por alguna sentencia discrepante de las anteriormente indicadas ${ }^{225}$, por ser el que contemplaba el Real Decreto 1398/1993, al haber sido derogado tal Real Decreto por la Ley 39/2015 y no haber sido asumido por la misma, para el procedimiento sancionador general.

C) También puede considerarse aplicable la denominada caducidad impropia del procedimiento sancionador prevista hoy en los arts.30.2 segundo párrafo y 30.3 segundo párrafo de la Ley 40/2015, por paralización del procedimiento durante más de un mes por causa no imputable al presunto responsable o infractor, que da lugar a la reiniciación del plazo de prescripción de infracciones y sanciones respectivamente.

Pues, por un lado, ya no existe, como ocurría en el marco de la Ley 30/1992, un precepto que excluya la aplicación a la potestad disciplinaria de los preceptos previstos para la potestad sancionadora general, mientras que por otro lado el art. 25.3 de la ley 40/2015 dice que las disposiciones de los arts. 25 y ss. de la misma son extensivas al ejercicio de la potestad disciplinaria respecto del personal a su servicio y ya hemos visto que el Reglamento de disciplina académica (Disposición Final y Transitoria $4^{\mathrm{a}}$ ) entiende aplicable supletoriamente la normativa sobre régimen disciplinario de la función pública, además de, con carácter general, los principios generales del Derecho Penal y del Derecho Procesal Penal.

\subsection{Los órganos competentes para incoar, tramitar y resolver el procedimiento disciplinario y las exigencias de los principios de objetividad e imparcialidad}

A) El RDA de 1954 establece dos competencias distintas: la del Ministerio de Educación para sanciones impuestas por faltas graves de los escolares (art. 23.1) y la de los Jefes de Centro, oídos los Claustros, Juntas o Consejos Asesores respectivos, cuando así proceda, respecto de las sanciones impuestas por las faltas muy graves y leves cometidas por los escolares (art. 24).

Además, precisa que, en el caso de Ministerio, si se trata de sanciones de inhabilitación general y perpetua para cursar estudios, habrán de acordarse previo dictamen del Consejo Nacional de Educación.

Como también matiza que el Jefe de Centro, a efectos de dicho Reglamento, es el Rector de la Universidad (art. 26).

Lo anterior fue completado y modificado parcialmente por el Decreto 2457/1965, que dispone que la competencia de los rectores alcanzará a la privación de un alumno

procedimiento sancionador, alegada por el recurrente, por no haber transcurrido el plazo de doce meses, que establece el RD.33/1986, cuyo plazo, que tiene rango de ley, es aplicable al supuesto litigioso, al asumirlo el propio Reglamento de Disciplina Académica, aplicable al alumnado, por la vía de su Disposición Final $4{ }^{\mathrm{a}}$.

225 D. CÁMARA DEL CASTILLO (2011, ps. 161-162) cita en este sentido la STSJ de Madrid (Contencioso, Sección

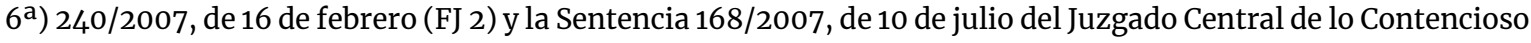
$\mathrm{n}^{0} 6$ (PO 101/2006), FJ 4, que no hemos podido localizar. 
de continuar estudios en su distrito universitario (salvo que el centro en cuestión fuese el único entre los de su clase en todo el territorio nacional); con lo cual se le están atribuyendo competencias de expulsión temporal o perpetua de los centros comprendidos en el distrito de su Universidad y la expulsión temporal o perpetua de su Universidad.

Así pues, la única sanción que se deja a la competencia del Ministerio es la inhabilitación temporal o perpetua de cursar estudios en todos los centros docentes, o sea en todas las Universidades de España; manteniéndose en el caso de que no sea temporal, sino permanente, el Dictamen preceptivo del Consejo Nacional de Educación. Esta competencia del Rector respecto de su Universidad se refuerza con la autonomía universitaria, reconocida a las Universidades en el art. 27.10 de la Constitución y desarrollada en las Leyes Orgánicas 11/1983, de Autonomía Universitaria, y 6/2001, de

Universidades. Además, aunque no se mencione en estas leyes expresamente, la competencia de los Rectores en dicha materia encuentra su cobertura en la competencia residual de éstos reconocida en los arts. 18.1 de la LRU y 20.1 de la LOU ${ }^{226}$.

Conforme al texto del Reglamento de 1954, en el supuesto de las faltas graves en el que el Rector de turno crea necesario que se produzca una inhabilitación temporal o permanente en todos los centros universitarios de España, al no ostentar él competencia sobre ello, porque claramente desborda su radio de acción, sólo le cabe elevar el expediente con su informe al Ministerio, a tenor del art. 14, párrafo sexto, del Reglamento, para que éste sea quien dicte la resolución pertinente ${ }^{227}$.

Pero, en la época de estas dos leyes, no tengo noticia de que se haya impuesto a algún alumno sanción por el Ministerio de inhabilitación temporal o permanente para cursar estudios en todas las Universidades españolas.

B) Una cuestión importante es la previsión de quiénes determinan la incoación del procedimiento, respecto de la cual indica el Reglamento de 1954 que se iniciará de oficio, a solicitud motivada de cualquier catedrático, profesor, miembro del servicio, alumno o persona interesada, o en virtud de orden de la superioridad. Pero, el Decreto $2457 / 1965$ parece modificarlo, al decir que se hará de oficio o a instancia de cualquier profesor del Centro, o sea, de la Universidad (art. 1).

Y una segunda cuestión relevante es la referencia a que la competencia de los rectores se ejercerá con audiencia de los claustros, juntas o consejos asesores respectivos, cuando así proceda (art. 24 del RDA).

Se plantea aquí el tema del carácter reglado o discrecional de la incoación del procedimiento y su resolución; de quienes están legitimados para solicitar su iniciación y recurrir, en su caso, si no se acuerda o si declara el sobreseimiento, sin imposición de

226 D. CÁMARA DEL CASTILLO (2011, p. 156).

227 J. PEMÁN GAVÍN, por un lado, dice que la competencia ministerial afirmada en el Reglamento de 1954 no encaja en un ordenamiento universitario que parte de un amplio reconocimiento de la autonomía de las Universidades (1994, p. 455). Pero, por otro, añade que solamente cabría hacer una salvedad en relación con la inhabilitación para cursar estudios universitarios, que, por su proyección general en relación con todas las Universidades españolas, parece debe corresponder a un órgano estatal con competencias sobre todo el territorio nacional (1994, p. 455, nota 48). 
sanción alguna; y de qué órganos de la Universidad deben intervenir en la decisión de tal incoación y la supervisión de la resolución, para garantizar, en último término, la imparcialidad y objetividad de la misma.

Pues el problema nuclear del ejercicio de la potestad disciplinaria de los alumnos (al igual que la que se ejerce sobre el personal docente y no docente) es que se ejerza cuando se deba ejercer, es decir, siempre que se planteen supuestos objetivos que requieran la garantía del orden dentro de la organización y del buen funcionamiento del servicio encomendado (fraude en los exámenes por cualquier método; ofensas al profesorado que minan su ascendiente sobre los alumnos en la impartición de docencia; graves ofensas a otros alumnos o al personal de administración y servicios de la Universidad; agresiones físicas a cualquier miembro de la comunidad académica).

$\mathrm{Y}$ es que lo anterior excluye el ejercicio según libre criterio (propio de la discrecionalidad) o de conveniencia personal de quien ostenta la autoridad académica en cada momento, que entonces podría dejar de ejercerla cuando objetivamente se debiera ejercer (por no resultar impopular entre los alumnos a los que tiene que pedir votos en el correspondiente proceso electoral $u$ órgano colegiado en el que ellos participan) o podría ejercerla cuando no debiera (con finalidad represora, por ejemplo, de alumnos que han apoyado o apoyan a otros candidatos en los distintos procesos electorales) o ejercerla de modo discriminatorio (no a alumnos protegidos por la propia autoridad académica o por determinado profesorado próximo a ella, pero sí a otros alumnos próximos a profesores que no sean amigos políticos o a alumnos simplemente no protegidos por nadie).

a) Frente a ello, cabe resaltar en primer término que la posición predominante en la jurisprudencia ${ }^{228}$ y en la doctrina científica 229 es la del carácter reglado y no discrecional del ejercicio de la potestad sancionadora de la Administración y, por ende, de la incoación de su procedimiento.

Así pues, es exigible, sobre la base de la jurisprudencia del Tribunal Supremo, la incoación del procedimiento sancionador o al menos el trámite de las actuaciones previas preliminares (que también se ha llamado fase de información previa o reservada), sin que quede a la libre disposición del Rectorado de la Universidad,

228 SSTS 24/9/1976 (RJ 1976\4564); 30/4/1979 (RJ 1979\1592); 2/6/1986 (RJ 1986\4608);

25/5/1987 (RJ 1987\5844, FJ 2); 4/5/1999 (RJ 2000\10096, FJ 7); 16/2/2000 (RJ 2000\961, FJ

2); 8/10/2001 (RJ 2002\6092, FJ 3.A); y 22/5/2002 (RJ 2002\7412, FJ $2^{\circ}$ ).

Y otras declaran al menos la obligación administrativa de realizar diligencias informativas (SSTS de 19/9/2002, RJ 2002\5076; y 10/3/2003, RJ 2003\3065).

Sin perjuicio de que se reconozca cierto margen de apreciación en la valoración de la conducta y su adecuación al tipo infractor y sancionador que corresponda, para aplicar el principio de proporcionalidad (SSTS de 8/3/1994, RJ 1994\1673; 1/2/1995, RJ 1995\1085; 7/3/1996, RJ 1996\2258; y 8/10/2001, RJ 2001\6092), pero ésta es una cuestión cualitativamente distinta a la existencia de discrecionalidad o no para incoar el procedimiento sancionador (A. RUIGÓMEZ MOMEÑE, 2013, p. 393).

229 E. GARCÍA DE ENTERRÍA y TOMÁS-RAMÓN FERNÁNDEZ (2013b, p. 198); M. GÓMEZ PUENTE (1997, p. 387 y ss); y B. LOZANO CUTANDA (2003, p. 83 y ss.).

Una posición doctrinal peculiar es la de A. NIETO GARCÍA (2006, ps. 131 y ss., especialmente ps 133-134), pues lo que viene a decir es que, aunque el fin de las sanciones es el cumplimiento de determinadas normas y que la tesis de la discrecionalidad o carácter facultativo ciertamente repugna al sentimiento de justicia y quebranta el principio de igualdad, así como genera una situación perversa, es la que se impone en la realidad de los hechos. Y, por eso y por su argumento de que el órgano judicial contencioso-administrativo no debe sustituir el criterio de la Administración por el suyo propio, acaba admitiendo la discrecionalidad y el carácter facultativo. 
una vez hecha la denuncia o dirigido el correspondiente Informe del Profesor correspondiente.

b) El problema se va a centrar entonces en que, a pesar del carácter reglado y no discrecional, si el órgano competente (en este caso, el Rectorado) no cumple con su obligación, se exige legitimación activa para recurrir el incumplimiento del deber de iniciar el procedimiento o de resolver en el mismo.

Es jurisprudencia del Tribunal Supremo que el denunciante sólo tendrá la consideración de interesado si ostenta interés legítimo ${ }^{230}$, es decir, si la sanción le puede producir un efecto positivo en su esfera jurídica o eliminar una carga o gravamen, teniendo en cuenta que la mera imposición de la sanción no se considera por sí misma la satisfacción de un interés ${ }^{231}$; de modo que, si finalmente se le reconoce interesado, estará legitimado para exigir el control jurisdiccional de una resolución como la impugnada ${ }^{232}$.

Pueden encontrarse en la jurisprudencia algunas manifestaciones del reconocimiento de que el denunciante ostentaba tal interés legítimo ${ }^{233}$.

A estos efectos, conviene aclarar que, a pesar de la restricción de personas que pueden promover la iniciación de oficio del procedimiento disciplinario realizada por el Decreto 2457/1965 con respecto al Reglamento de 1954, la interpretación de los mismos conforme a la Constitución y su art. 24, unido a la previsión por el art. 2.2.c de la Ley 39/2015 de la aplicación supletoria a las Universidades de lo dispuesto en dicha Ley, en defecto de su normativa específica, cabe admitir como denunciante a cualquier persona y como legitimado al denunciante o al Profesor que pueda acreditar un interés legítimo, por afectarle personalmente la imposición o no de la sanción y, por ello, la apertura o no del procedimiento disciplinario.

230 SSTS de 8/2/2001 (RJ 2001 \1154, FJ 5); de 6/3/2001 (RJ 2001\1811, FJ 4, letras D y E); y de 7/4/2003 (RJ 2003\3544, FJ 3).

231 SSTS de 8/2/2001 (RJ 2001\1154, FJ 5); y de 7/4/2003 (RJ 2003\3544, FJ 3).

Y destaca también que tal condición de interesado se producirá en los casos de reconocimiento de acción popular (STS de 7/4/2003, RJ 2003 3544, FJ 3); lo que ha sido matizado por el TC diciendo que, en el caso de la acción popular, se reconoce un interés legítimo y personal en la defensa del interés común (SSTC 62/1983 y 34/1994, FJ 2, párrafo tercero), como ocurre en el caso de la defensa del patrimonio natural (STC 34/1994, FJ 3, párrafo tercero), en el que el TC reconoció interés legítimo y personal en la defensa del interés común, en el ámbito penal, a una asociación ecologista, ante la revocación de la sanción impuesta a un cazador que había abatido una avutarda (STC 34/1994, FJ 3, párrafo tercero).

En este sentido, E. GARCÍA DE ENTERRÍA y TOMÁS-RAMÓN FERNÁNDEZ han considerado, en su momento, que el reparto sancionatorio entre la Administración y los Tribunales obligaba a extender aquí la acción popular del art. 125 CE (2013b, p.198).

232 STS de 6/3/2001, RJ 2001\1811, FJ 4, letra D

233 SSTS de 3 de junio de 1998 (RJ 1998\5046, FJ 3, en el caso del archivo de actuaciones del procedimiento sancionador a una empresa turística, porque ello afectaba a su reclamación de daños y perjuicios por responsabilidad civil) y 17/12/2001 (ROJ: STS 9921/2001, FJ 5, sobre sanción de un Abogado previa denuncia de otro, porque la sanción afectaba al denunciante personal y profesionalmente). Y un reconocimiento de facto de tal interés legítimo se manifiesta, asimismo, en la STS de 22/5/2002 (RJ 2002\7412), en el que se estimó finalmente el recurso de UNESPA frente al acuerdo del Director General de Defensa de la Competencia que decidió el archivo de las actuaciones originadas por la denuncia de la actora, en relación con el establecimiento de honorarios mínimos de los profesionales que se dedicaban a la práctica de la anestesiología y reanimación por una Asociación de Anestesiólogos, pues ello afectaba a los precios que tenían que pagar las aseguradoras. 
En el caso de que la incoación del procedimiento disciplinario haya sido promovida por los profesores universitarios (como prevé tanto el Reglamento de 1954 como el Decreto 2457/1965), si éste no se inicia o se archiva, se planteará la entrada en juego de la excepción a la legitimación del art. 20 de la LJCA, por considerar que ha actuado como órgano de la Universidad (claramente, cuando se trata de infracciones ligadas a los exámenes académicos, respecto de los cuales el profesor actúa como órgano calificador) o como agente o mandatario de la misma.

Pero en ningún caso, se le podría negar, según lo anteriormente expuesto, legitimación por titularidad de derechos subjetivos o intereses legítimos propios afectados, cuando acredite la lesión por la conducta infractora de un derecho subjetivo o de un interés legítimo suyo.

Ejemplo de derechos subjetivos afectados son el derecho a la vida y a la integridad física y moral, en el caso de las agresiones físicas por alumnos; el derecho al honor, a la intimidad personal y familiar y a la propia imagen, en el caso de injurias, calumnias $\mathrm{u}$ otras infracciones lesivas de tales derechos; o el derecho de propiedad, en el caso de que la infracción consista en robo, hurto, etc.

Ejemplo de intereses legítimos afectados son todas aquellas otras situaciones distintas de las anteriores en las que la infracción cometida por el alumno le afecte más que al resto de los ciudadanos, generándole un perjuicio o privándole de un beneficio, como, por ejemplo, cualquier ofensa proferida por un alumno que no se considere lesiva de los derechos subjetivos citados, pero que le perjudique desde el punto de vista profesional o personal. Aquí podrían incluirse ofensas realizadas por el alumno que impidan al profesor ejecutar su trabajo cotidiano como un trabajador más (que en este caso es la docencia) o con incidencia negativa en la evaluación de su docencia por los alumnos realizada mediante las encuestas.

$\mathrm{Y}$, en el caso de que la denuncia de infracciones de un alumno provengan de otro alumno o de personal no docente, se pueden plantear situaciones semejantes, sobre todo de lesión de derechos subjetivos del denunciante como el derecho a la vida y a la integridad física y moral, en el caso de las agresiones físicas; el derecho al honor, a la intimidad personal y familiar y a la propia imagen, en el caso de ofensas graves de palabra u obra a los mismos; o el derecho de propiedad, en el caso de que la infracción consista en robo, hurto, etc.

En todos estos casos, los profesores, alumnos y personal no docente promotores del ejercicio de la potestad disciplinaria y, a su vez, afectados por infracciones de dicho tipo realizadas por alumnos universitarios, tendrían legitimación para recurrir la no incoación de procedimiento disciplinario o el archivo de las actuaciones. Y lo mismo podría plantearse del personal ajeno a la comunidad universitaria, pero que trabaja ordinariamente en la Universidad, por formar parte de la plantilla de trabajadores de empresa contratista de servicios de la misma (conserjes o empleados de seguridad aportados por esos contratistas, p. ej.).

c) Un último aspecto a desarrollar es reflexionar sobre qué órganos de la Universidad deben intervenir en la decisión de tal incoación y la supervisión de la resolución, para garantizar, en último término, la imparcialidad y objetividad de la misma. 
Antes de nada, no debemos ocultar que el TC ha declarado que, en el caso de las sanciones disciplinarias, en el ámbito de relaciones especiales de sujeción y con referencia específica a los internos en un establecimiento penitenciario, las competencias sancionadoras se asignan a órganos administrativos y no es exigible esa neutralidad o imparcialidad en su composición que el recurrente reclama, propia de los órganos judiciales ${ }^{234}$.

Pero ello no quiere decir que no se exija que los órganos administrativos también actúen con imparcialidad y objetividad, porque así se deriva de lo dispuesto en la Constitución, cuando dice que la Administración sirve con objetividad los intereses generales (art. 103.1) y que la Ley regulará el estatuto de los funcionarios públicos y las garantías para la imparcialidad en el ejercicio de sus funciones (art. 103.3).

Lo que ocurre es que, en las Administraciones públicas, sin darse la independencia de los jueces y magistrados, la objetividad e imparcialidad se puede manifestar en la creación de entidades y órganos con autonomía orgánica y funcional235.

Hemos recordado atrás cómo el art. 24 del Reglamento de 1954, al establecer la competencia de los Jefes de Centro (o sea, los Rectores), alude a la audiencia de los Claustros, Juntas o Consejos Asesores respectivos, cuando así proceda.

Por lo tanto, contempla claramente la posibilidad que otras normas establezcan la intervención de órganos colegiados como los citados, con mayor o menor alcance. Estas normas serán fundamentalmente los Estatutos de la Universidad de referencia, pero también pueden ser otros Reglamentos universitarios, pues tanto la anterior Ley 30/1992 (art. 127.2) como la actual Ley 40/2015 (art. 25.2) tan sólo exigen, como requisito del principio de reserva de Ley, el reconocimiento al ente de la potestad sancionadora, pero no la precisión de los órganos competentes, que podrán establecerse tanto en normas con rango de Ley como en normas reglamentarias.

A mi entender, un modo razonable de salvaguardar la objetividad e imparcialidad en el momento de adopción de la decisión de incoar el procedimiento disciplinario o de acordar el archivo de las actuaciones es que dicha decisión se adopte por un órgano colegiado que ostente autonomía funcional y no dependencia jerárquica y cuyos miembros sean elegidos por el claustro universitario por mayoría reforzada y no designados directamente por el Rectorado o por otro órgano unipersonal.

Lo cual, a su vez, libera al Rector de correr con todo el peso de la misma y de lo ingrato que ello puede resultar para el mismo en la mayor parte de las ocasiones.

Aunque, lo anterior, sin perjuicio de respetar el carácter reglado de la potestad y la impugnabilidad de la resolución adoptada por los legitimados titulares de derechos subjetivos o intereses legítimos afectados por la eventual sanción a imponer.

Un ejemplo que se acerca al modelo propuesto, proveniente de nuestro sistema universitario, aun sin cumplir todos los requisitos indicados, es el de una Comisión

234 SSTC 74/1985, FJ 2, párrafo segundo; 2/1987, FJ 4, último párrafo; y 190/1987, FJ 4, párrafo segundo.

S. FERNÁNDEZ RAMOS y J.M. PÉREZ MONGUIÓ (2012, p. 25). 
de Disciplina tal y como la que previó el Estatuto de la Universidad de Oviedo de $1985^{236}$.

Estaba compuesta por el Rector, el Secretario General, un miembro del Consejo Social y cuatro profesores nombrados por el Rector a propuesta de la Junta de Gobierno por un período de 4 años.

Después, en virtud de lo dispuesto en su Reglamento de régimen interno, aprobado por la Junta de Gobierno de la Universidad en $1998^{237}$, se dispuso que tal comisión tenía que emitir un informe, en el plazo de quince días, sobre la conveniencia o no de la incoación del expediente disciplinario. Y parece que dicho informe era vinculante, porque, en otro precepto de tal Reglamento, se decía que el Rector ordenaría la apertura del expediente y nombraría Instructor, en el caso de que se hubiese decidido la apertura del mismo.

A dicha Comisión le faltaba, para cumplir con el modelo que he propuesto, que el nombramiento de los vocales se hubiese realizado por el Claustro Universitario con la mayoría reforzada indicada, para garantizar una fuerte representatividad respecto de toda la comunidad universitaria y una representación, aunque fuese mínima, del personal de administración y servicios y del alumnado.

Y otro ejemplo, esta vez de Derecho Comparado, es el del Derecho Francés, arriba descrito, basado en secciones disciplinares de los Consejos Académicos, cuyos miembros serán elegidos por estos mismos de entre sus integrantes, a razón de seis profesores, por un lado, y seis usuarios del servicio (alumnos por otro), con exclusión expresa del Rector de la Universidad. Pues, además, de la descripción que el Ordenamiento francés realiza de tal órgano, se colige claramente su autonomía funcional y por lo tanto su independencia a la hora de acordar la incoación del procedimiento y la resolución del mismo, frente al que, asimismo, cabe un recurso administrativo ante el Consejo Nacional de Educación Superior e Investigación (CNESER).

Preferimos este modelo al de decisión por órganos tan amplios como el Senato Académico de las Universidades italianas (correlato de nuestro Claustro Académico), porque, debido a tal amplitud, a su carácter más político que técnico y a su falta de especialización en el enjuiciamiento de las infracciones de este tipo, su decisión puede ser en algunos casos más política que jurídica, cuando, a nuestro entender, la misma sólo debería ser fundada en Derecho.

Consideramos, pues, más adecuado un órgano integrado por personas elegidas por el Claustro con una mayoría cualificada, que se especialice en la materia disciplinaria y que goce de autonomía funcional, sin que el nombramiento de sus miembros pueda ser revocado libremente durante su mandato.

236 Art. 167 del RD.1295/1985, de 3 de julio (BOE del 1 de agosto), derogado al aprobarse el Estatuto de 2003 y éste al aprobarse el vigente de 2010 , en los cuales no se ha contemplado dicho órgano, sino una Inspección de servicios para funciones de instrucción y bajo la dependencia jerárquica del Rectorado (Disposición Adicional Tercera del Decreto 12/2010 del Consejo de Gobierno de Asturias), como en otras Universidades.

237 Acuerdo de su Junta de Gobierno de 4 de diciembre de 1998, arts. 11 y 12. 


\section{Conclusiones y valoración crítica}

1. A la vista de la jurisprudencia constitucional sobre la potestad sancionadora en el ámbito de las relaciones de sujeción especial, podemos concluir que el régimen disciplinario de los alumnos universitarios entra dentro de dicho ámbito por el criterio de la "garantía del orden y buen funcionamiento del servicio" y no tanto por el criterio que alude a "situaciones y relaciones administrativas donde la Constitución, o la ley de acuerdo con la Constitución, han impuesto límites en el disfrute de los derechos constitucionales, modulándolos".

2. La regulación en España de tal régimen disciplinario viene determinada actualmente por el Reglamento de Disciplina Académica de 1954 y por Reglamentos universitarios que se justifican como especificación actualizada o complemento del Reglamento de $1954^{238}$.

3. La compatibilidad del Reglamento de disciplina académica de 1954 con el principio de reserva de ley se apoya en la jurisprudencia constitucional, arriba citada, que declara que se consideran conformes con dicho principio las normas reglamentarias preconstitucionales producidas en materias no reservadas a la ley antes de la Constitución.

4. Sin embargo no encajan bien con la jurisprudencia del Tribunal Constitucional los Reglamentos autocalificados como especificación del Reglamento de 1954, por existir sentencias del Tribunal Constitucional que dicen expresamente que no son conformes con el principio de reserva de Ley los reglamentos de ejecución de reglamentos preconstitucionales no amparados en una habilitación legal previa.

5. Otra conclusión nos merece el caso de los eventuales Reglamentos sustitutivos del Reglamento de 1954 por las razones arriba detalladas y que ahora resumimos.

Antes de la STC 61/1990, el TC reconoce expresamente en la STC 219/1989 la posibilidad de reglamentos tipificadores de infracciones y sanciones en relaciones especiales de sujeción cuando hay norma con rango de ley habilitante, aun cuando se trate de una remisión inespecífica con ausencia de contenido.

La STC 61/1990, destacada como determinante del giro jurisprudencial en el sector de las relaciones de sujeción especial no acaba de indicar claramente que esto cambie. Pues, aunque resalte que no sea posible, en este tipo de relaciones, la supresión de los derechos constitucionales como el del art. 25.1 CE, acaba diciendo que admite una adaptación en tales casos.

La STC 26/2005 dice que, "con independencia de cómo se denomine la relación que une a la titular de la concesión con la Administración, no hay fundamento alguno para que la infracción por la que se sancionó a la recurrente carezca de la cobertura legal que, con carácter general, exige el art. 25.1 CE", adicionando acto seguido, con la

238 Reglamento de régimen disciplinario de los estudiantes de la Universitat Pompeu Fabra, aprobado por Acuerdo de su Consejo de Gobierno de 18 de julio de 2012. Reglamento de régimen disciplinario de los estudiantes de la Universitat Rovira i Virgili, aprobado por Acuerdo del Consejo de Gobierno de tal Universidad de 18 de diciembre de 2013. Normativa sobre conducta académica de la Universidad Rey Juan Carlos", aprobada por su Consejo de Gobierno de 28 de febrero de 2014. 
conjunción "pues", que «la Ley sancionadora ha de contener los elementos esenciales de la conducta antijurídica y la naturaleza y límites de las sanciones a imponer". Pero las sentencias que menciona para este último resultado no son atinentes, ninguna de ellas, a relaciones de sujeción especial y ella misma tampoco lo es (pues versa sobre un concesionario de expendeduría de tabaco), por lo que no dejaría de ser un pronunciamiento obiter dicta para dicho tipo de relaciones.

Y las sentencias posteriores a las dos anteriormente citadas (SSTC 188/2005; 229/2007; y187/2015), que sí son propias de las relaciones de sujeción especial, tampoco aclaran definitivamente la cuestión, pues no requieren que la Ley sancionadora haya de contener los elementos esenciales citados, sino que lo único que dicen es que tampoco respecto de las relaciones de sujeción especial goza la Administración de un poder normativo carente de habilitación legal, aunque ésta pueda otorgarse en términos que no serían aceptables sin el supuesto de esa especial relación. Y lo lógico es que, si realmente se hubiese consolidado, en la jurisprudencia constitucional, también para este tipo de relaciones, el criterio de que la Ley sancionadora hubiese de contener los elementos esenciales de la conducta antijurídica y la naturaleza y límites de las sanciones a imponer, se hubiese indicado en tales sentencias y no se ha hecho.

Por ello, no es extraño que haya Sentencias del TS, que citamos arriba, con las dos interpretaciones opuestas y que tal oscuridad tenga reflejo en sentencias de órganos jurisdiccionales inferiores arriba indicadas.

Así pues, una cosa es que sea deseable lege ferenda una tipificación mínima de infracciones y sanciones por norma con rango de ley o, al menos, en la línea de la STC 132/2001, de los criterios de antijuridicidad de las infracciones y de las clases de sanciones posibles y otra cosa es que sea exigible lege data, sobre la base de la jurisprudencia constitucional existente, por lo que no podrían ser tachados de descabellados Reglamentos universitarios tipificadores de infracciones y sanciones basados únicamente en la habilitación legal derivada del art. 46.2 de la LOU.

En el Derecho comparado de los países de nuestro entorno más inmediato, podemos comprobar que tampoco puede decirse que, en esta materia, exista una regulación legal sin remisión inespecífica, al menos en el ámbito de las infracciones.

En el Derecho Italiano, si bien el cuadro de sanciones sí que está recogido en una norma con rango de ley (el Real Decreto-Ley de 1935), no puede afirmarse lo mismo de las infracciones, en las que el Real Decreto-Ley de 1935 tan sólo recoge el tipo genérico ("hechos lesivos de la dignidad y el honor - de la institución y de las personas-").

Y, en el Derecho Francés, aunque puede encontrarse una base de normas con rango de ley anteriores, tanto para las sanciones como para algunas de las infracciones, el cuadro de ambas viene regulado actualmente por normas de rango reglamentario.

6. Nuestra opinión de lege ferenda o nuestra propuesta de jurisprudencia constitucional relativa al rango legal de la regulación sí que es que se tipifiquen las infracciones y las sanciones en normas con rango de ley.

Por un lado, porque, habiendo calificado la jurisprudencia constitucional la legalidad sancionadora del art. 25.1 CE como derecho subjetivo fundamental (SSTC 
42/1987; 77/1983; y 61/1990), habrá que aplicar también la doctrina constitucional de dicha jurisprudencia según la cual, ante dos interpretaciones posibles, siempre habrá que optar por la más favorable a la eficacia de un derecho fundamental

Y, por otro, porque, habida cuenta, a su vez, de que, en este ámbito, resulta afectado, sobre todo, el derecho a la educación y de que, con una norma con rango de ley estatal, se asegura una regulación uniforme mínima para todas las Universidades públicas del Estado, como ocurre en el Derecho Francés. Cuando, además, hay fuertes argumentos en favor de la competencia estatal en esta materia, al afectar esta materia a las "normas básicas para el desarrollo del artículo 27 de la Constitución" del art. 149.1.30 CE y al responder al título competencial del art. 149.1.1 CE (asegurar la regulación de las condiciones básicas que garanticen la igualdad de todos los españoles en el ejercicio de los derechos y el cumplimiento de los deberes constitucionales).

Aunque ello, sin perjuicio, de las competencias normativas sancionadoras de las CCAA admitidas por nuestra jurisprudencia constitucional en los términos arriba reseñados (es decir, sin una diferencia de trato sustancial o salto sancionador cualitativo que rompa la unidad en lo fundamental del esquema sancionatorio y con respeto a la exigencia de una igualdad en las posiciones jurídicas fundamentales que el art. 149.1.1 CE conlleva).

7. En cuanto al principio de tipicidad, puede decirse que el texto de nuestro Reglamento de 1954, aun siendo un tanto obsoleto, cubre bastante bien los supuestos actuales, habida cuenta de que éstos son reconducibles a los conceptos jurídicos indeterminados recogidos en el mismo.

Máxime si tenemos en cuenta que el Tribunal Europeo de Derechos humanos, en su Sentencia de 8 de diciembre de 2015 ha considerado lo mismo en el caso italiano, cuya tipificación de infracciones está recogida en un tipo muy genérico, de mucho menor especificación que los tipos de nuestro Reglamento de 1954.

8. Por cuanto respecta al principio non bis in idem, no plantea especiales problemas en este ámbito, ya que en el mismo se admite la dualidad de sanciones, al ser característica de la potestad sancionadora disciplinaria que concurra un fundamento distinto, un interés protegido diverso, al de la potestad penal. Así se contempla por el RDA de 1954, al recoger como infracción grave disciplinaria la constitutiva de delito (art. 5.a. $5^{\text {a }}$ ), que supone la previsión de que las conductas tipificadas como delito en el Código Penal y objeto de sanción penal se sancionen, a su vez, con sanciones disciplinarias. Y así se ha reconocido en sentencias del orden jurisdiccional contencioso-administrativo en las que se habían invocado condenas penales por los mismos hechos y sujetos, como las que reseñamos supra.

9. La aplicación de los otros principios de la potestad sancionadora, especialmente el de proporcionalidad y la consiguiente ponderación de las sanciones disciplinarias con los derechos fundamentales en juego, como el de educación o el de libertad de expresión, puede decirse que se está realizando correctamente por los órganos judiciales españoles, en la misma línea que el Tribunal Europeo de Derechos Humanos, como hemos visto.

Pues, realmente, no estamos tanto ante la restricción de derechos por la inserción de los ciudadanos afectados en una relación especial de sujeción, sino ante la cuestión 
general de los límites del ejercicio de los derechos derivados de la necesidad de respetar los derechos de otros (de los profesores, de otros alumnos o incluso del personal de administración y servicios) o del respeto del interés general (en este caso, representado por el sistema educativo), que no puede permitir evaluaciones positivas del rendimiento académico basadas en el fraude o no puede admitir la lesión de los derechos de otros miembros de la comunidad universitaria cuyo respeto es necesario para la convivencia en los centros educativos.

Así pues, aunque, como hemos visto, las sanciones disciplinarias a los estudiantes universitarios se acomodan perfectamente al criterio de nuestra jurisprudencia constitucional de "garantía del orden y buen funcionamiento del servicio", dichas sanciones podrían configurarse perfectamente como sanciones administrativas generales, con los mismos fines y razón de ser de éstas. Se configurarían así, como sanciones administrativas generales sectoriales del ámbito educativo, del mismo modo que existen en el ámbito urbanístico, en el del comercio interior, etc.; en cuyo caso ya no cabría invocar modulación alguna respecto del principio de reserva de ley o del de tipicidad y quedaría ausente de justificación la excepción al principio non bis in idem.

10. Igualmente puede considerarse correcto -a nuestro entender- el tratamiento por nuestros textos normativos y por la jurisprudencia analizada del derecho a la presunción de inocencia, con el reconocimiento de prueba por presunciones y la necesidad de considerar como prueba de cargo suficiente la determinada por los informes del profesor universitario, en su condición de agente de autoridad que ha presenciado los hechos en el ejercicio de sus funciones.

11. A pesar de no estar contemplado en el Reglamento de 1954 plazo de prescripción alguno, debemos entender hoy aplicables a las infracciones y sanciones del mismo los plazos de prescripción del art. 30 de la Ley 40/2015. Como plazo de caducidad, debemos considerar aplicable el de 12 meses previsto para el régimen disciplinario de los funcionarios al servicio de la Administración General del Estado, introducido por el art. 69.1 de la ley 24/2001. E, igualmente, no puede dejar de ser aplicada al procedimiento disciplinario de los alumnos universitarios la caducidad impropia prescrita en los arts. 30.2, segundo párrafo, y 30.3, segundo párrafo, de la Ley 40/2015.

12. El mayor problema que presenta la potestad disciplinaria de los alumnos, al igual que la de personal docente o no docente de las Universidades, es dejar de utilizarse cuando el alumno infractor tiene valedores o amistades próximas el equipo rectoral, que hacen que no se le aplique el régimen disciplinario, mientras que sí se aplica a aquellos otros alumnos que se identifican con sectores distantes del equipo rectoral o simplemente que no tienen ningún respaldo entre las personas próximas a dicho equipo. Es el clásico problema del uso de la potestad disciplinaria discriminando según se trate de amigos, enemigos o indiferentes, cuando, por el contrario, se debe asegurar que un poder excepcional (así lo califica la jurisprudencia constitucional), al tratarse de poder sancionador, se utilice de modo escrupulosamente igualitario, objetivo e imparcial.

Pues, como todo poder sancionador, tiene naturaleza reglada y no discrecional y, por ello, la incoación del procedimiento o no y el archivo de las actuaciones no deben 
estar a merced de la voluntad del Rectorado de turno o de órganos jerárquicamente subordinados a éste.

Por eso, lo mejor es confiar tales facultades a órganos que gocen de autonomía funcional y no de dependencia jerárquica, a fin de que no tengan que seguir instrucciones jerárquicas o directrices políticas del Rectorado o de ningún otro órgano. Y, por la misma razón, es importante que sus miembros accedan a tal órgano por elección dotada de amplísima representación y no por designación directa basada en la denominada confianza (ya sea política, ya sea de pura amistad). En este sentido, lo más oportuno en nuestro sistema es que tales miembros sean elegidos por el claustro universitario, mediante mayoría muy cualificada.

Las secciones disciplinarias de los Consejos Académicos en el sistema francés es un ejemplo de ello, por ser sus miembros integrantes elegidos y no designados por el titular de otro órgano y, además, por situarse alejados del Rectorado y de los Decanatos. Si bien, el defecto que le encontramos es la representación sobredimensionada que tienen los alumnos en el mismo, porque, aunque ésta debe existir, debería ser más moderada, para que no existiesen sesgos de proximidad de intereses que puedan mediatizar su actuación imparcial y ajustada totalmente a Derecho.

\section{Referencias}

Alegre Ávila, J.M. (2013). "Una pincelada al hilo de una noticia periodística sobre la potestad sancionadora de las Universidades en relación con los estudiantes universitarios", en Publicaciones de los miembros de AEPDA, el 16 de mayo de 2013.

Cámara del Castillo, D. (2011). El trato a los rebeldes a un nuevo orden docente de grupo y estructuras. El nuevo régimen de disciplina académica. ¿O convivencial? IX Seminario de Aspectos jurídicos de la Gestión Universitaria. Logroño de 26 a 28 de mayo de 2010. Universidad de La Rioja.

Casetta, Elio (2011). Manuale di diritto amministrativo. Tredicesima edizione. Giuffrè. Milano.

Castillo Blanco, F.A. (1992). Función pública y poder disciplinario del Estado, Civitas/ CEMCI, Madrid, 1992.

Chinchilla Marín, C. (1989). "El nuevo régimen disciplinario de los alumnos no universitarios", REDA, n. ${ }^{\circ} 64$.

Fernández Ramos, S. y Pérez Monguió, J.M. (2012). La imparcialidad en el procedimiento administrativo: abstención y recusación. Ed. Thomson-Reuters-Aranzadi. Cizur Menor (Navarra).

Gallego Anabitarte, A. (1961). "Las relaciones especiales de sujeción y el principio de la legalidad de la administración", RAP, nº 34 .

García De Enterría, E., (1976). "El problema jurídico de las sanciones administrativas". REDA n ${ }^{\circ} 10$, p. 399 y ss.

García de Enterría E. y Fernández Rodríguez, T.R.: (2013b). «Curso de Derecho Administrativo», Tomo II, Ed. Thomson Reuters-Civitas. $13^{\mathrm{a}}$ edición, Madrid.

García de Enterría E. y Fernández Rodríguez, T.R.: (2015a). «Curso de Derecho Administrativo», Tomo I, Ed. Thomson Reuters-Civitas. $15^{\mathrm{a}}$ edición, Madrid. 
García de Enterría E. y Fernández Rodríguez, T.R.: (2015b). «Curso de Derecho Administrativo», Tomo II, Ed. Thomson Reuters-Civitas. $14^{\mathrm{a}}$ edición, Madrid.

García Macho, R. (1992). Las relaciones de supremacía especial en la Constitución española, Tecnos, Madrid, 1992.

Gómez García, M.J. (2009). La Potestad sancionadora de las Universidades, en Comentario a la Ley Orgánica de Universidades, dirigido por Julio V. González García, CivitasThomson, Cizur Menor, 2009, ps. 603-635.

Gómez Puente, M. (1997). La inactividad de la Administración. Ed. Aranzadi. Cizur Menor (Navarra).

González Beilfuss, M. (2003). "El principio de proporcionalidad en la Jurisprudencia del Tribunal Constitucional". Ed. Thomson-Aranzadi. Cizur Menor (Navarra).

González Mariñas, P. (1973). Reflexiones sobre el Derecho disciplinario: delimitación de la llamada «falta de probidad», Documentación Administrativa ${ }^{\circ} 155$.

Jiménez-Blanco y Carrillo de Albornoz, A. (1989). Derecho público del Mercado de Valores, Centro de Estudios Ramón Areces, Madrid.

Jiménez Soto, I. (2015). El régimen disciplinario de los estudiantes universitarios. Un andamio difícil de sostener con algunas piezas sueltas. REDA 168, ps. 259-286.

Lasagabaster Herrarte, I. (1994). Las relaciones de sujeción especial, Civitas/ Organismo Autónomo del Gobierno Vasco, Madrid.

López Benítez, M. (1994) Naturaleza y presupuestos de las relaciones especiales de sujeción, Civitas/Universidad de Córdoba, Madrid..

Lozano Cutanda, B. (2003). El principio de oficialidad de la acción sancionadora administrativa y las condiciones necesarias para garantizar su efectividad. RAP 161, p. 83 y ss.

Marina Jalvo, B. (2006). El régimen disciplinario de los funcionarios públicos, Lex Nova, 3.a edición, Valladolid.

Nieto García, A. (1970). "Problemas capitales del Derecho disciplinario", RAP, n. 63.

Nieto García, A. (1999). "Régimen disciplinario del alumnado universitario: Perspectivas para su configuración". En el volumen colectivo coordinado por Luciano Cordero Saavedra "Las Universidades públicas y su régimen jurídico". Ed. Lex Nova.Valladolid, p. 527 y ss.

Nieto García, A. (2006). Derecho Administrativo Sancionador. $4^{\mathrm{a}}$ edición. Ed. Tecnos. Madrid.

Pemán Gavín, J. (1994). "El régimen disciplinario de los estudiantes universitarios: sobre la vigencia y aplicabilidad del reglamento de disciplina académica (Decreto de 8 de septiembre de 1954). RAP no 135.

Quintana López, T. (2009). "La potestad disciplinaria de las Administraciones sobre los empleados públicos". Documentación administrativa, $\mathrm{n}^{0}$ 282-283, 2009, ps. 321-359.

Rebollo Puig, M.; Izquierdo Carrasco, M.; Alarcón Sotomayor, L.; Bueno Armijo, A.M. (2010). Derecho Administrativo Sancionador. Ed. Lex Nova. Valladolid.

Ruigómez Momeñe, A. (2013). El inicio del procedimiento sancionador. En "Manual de Derecho Administrativo Sancionador". Abogacía General del Estado. Dirección del Servicio Jurídico del Estado. $3^{\mathrm{a}}$ edición. Ed. Thomson-Reuters-Aranzadi. Tomo I, p. 389 y ss.

Santamaría Pastor, J.A. (2009). "Principios de Derecho Administrativo General". Tomo II. Ed. IUSTEL. $2^{\text {a }}$ edición en dicha editorial. Madrid.

Souvirón Morenilla, J.M. y Palencia Herrejón, F. (2002). La nueva regulación de las Universidades. Comentarios y análisis sistemático de la Ley Orgánica 6/2001 de 21 de 
diciembre, de Universidades. Ed. Comares. Granada.

Suay Rincón, J. (1989). "Potestad disciplinaria", Libro homenaje a José Luís Villar Palasí, Civitas, Madrid, 1989.

Tardío Pato, J.A. (2003). "Legislación universitaria". Ed. Thomson-Aranzadi. Cizur Menor (Navarra). (2011). "Los Principios Generales del Derecho: Su aplicación efectiva como Normas Jurídicas". Ed. Bosch SA. Barcelona.

Tornos Mas, J. (2010). "El Régimen Disciplinario de los Estudiantes Universitarios". Ponencia del XIII Encuentro Estatal de Defensores Universitarios celebrado en Barcelona.

Trayter Jimenez, J.M. (1992). "Manual de Derecho Disciplinario de los funcionarios públicos". Ed. Marcial Pons. 